Prepared in cooperation with the New York City Department of Environmental Protection

\title{
Bathymetry of New York City's East of Hudson Reservoirs and Controlled Lakes, 2017 to 2019
}


Front cover. [top] A bridge on the Taconic Parkway over New Croton Reservoir, New York. [middle] The dam and spillway at New Croton Reservoir. [bottom] A U.S. Geological Survey boat at Bog Brook Reservoir. Photographs by Elizabeth Nystrom, U.S. Geological Survey.

Back cover. New Croton Reservoir in New York; photograph by Elizabeth Nystrom, U.S. Geological Survey. 


\section{Bathymetry of New York City's East of Hudson Reservoirs and Controlled Lakes, 2017 to 2019}

By Elizabeth A. Nystrom, Courtney J. Huston, and Robert J. Welk

Prepared in cooperation with the

New York City Department of Environmental Protection

Scientific Investigations Report 2021-5057 


\section{U.S. Geological Survey, Reston, Virginia: 2021}

For more information on the USGS - the Federal source for science about the Earth, its natural and living resources, natural hazards, and the environment—visit https://www.usgs.gov or call 1-888-ASK-USGS.

For an overview of USGS information products, including maps, imagery, and publications, visit https://store.usgs.gov/.

Any use of trade, firm, or product names is for descriptive purposes only and does not imply endorsement by the U.S. Government.

Although this information product, for the most part, is in the public domain, it also may contain copyrighted materials as noted in the text. Permission to reproduce copyrighted items must be secured from the copyright owner.

Suggested citation:

Nystrom, E.A., Huston, C.J., and Welk, R.J., 2021, Bathymetry of New York City's East of Hudson reservoirs and controlled lakes, 2017 to 2019: U.S. Geological Survey Scientific Investigations Report 2021-5057, 46 p., https://doi.org/10.3133/sir20215057.

Data associated with this publication:

Nystrom, E.A., Huston, C.J., and Welk, R.J., 2021, Geospatial bathymetry datasets for New York City's East of Hudson reservoirs and controlled lakes: U.S. Geological Survey data release, https://doi.org/10.5066/P9ZZO20T.

ISSN 2328-0328 (online) 


\section{Acknowledgments}

The authors would like to thank the New York City Department of Environmental Protection, notably, Jordan Gass and Adolf Jonietz, for providing practical information about the reservoirs and local datums and additional survey data for quality assurance use, Lori DiLorenzo for coordinating reservoir access, and Michael Ansaldi and the boat office crew for steam cleaning the boat many times. The authors would also like to thank Meaghan Keefe and Todd Campbell of the U.S. Geological Survey for their immense help in collecting the data used in this report. 



\section{Contents}

Acknowledgments ……...................................................................................................................

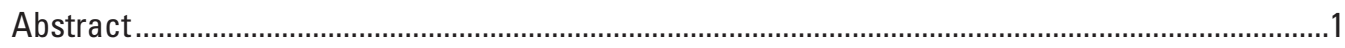

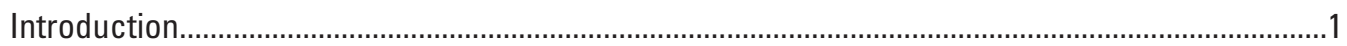

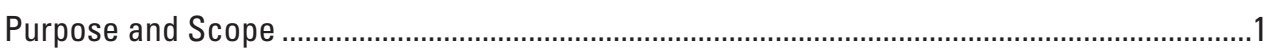

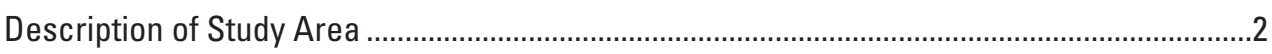

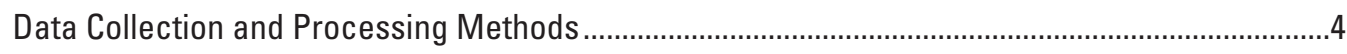

Vertical Control and Water Surface Elevation ..........................................................................

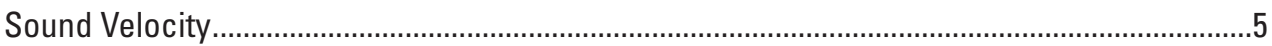

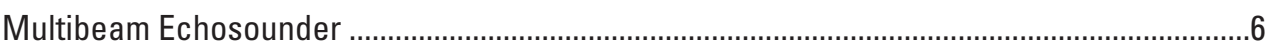

Multibeam Echosounder Data Collection .......................................................................

Multibeam Echosounder Data Processing ......................................................................

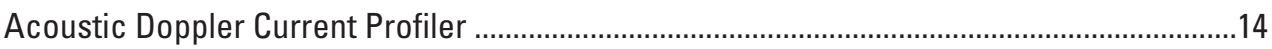

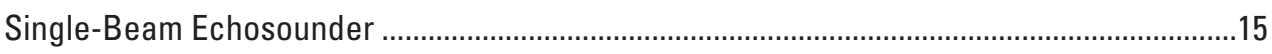

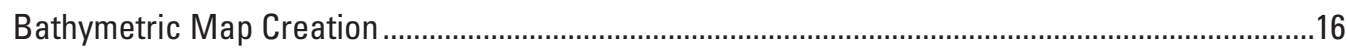

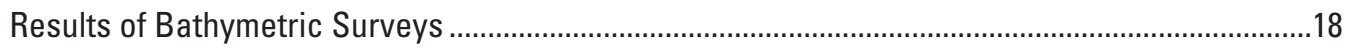

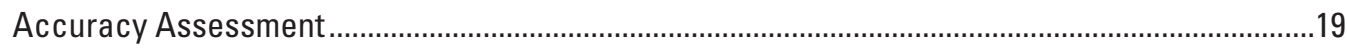

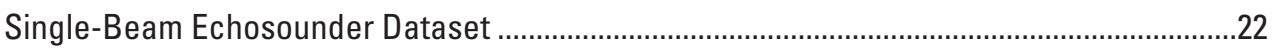

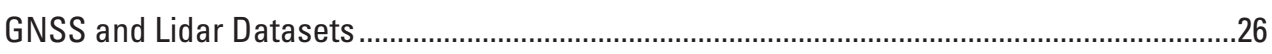

Summary

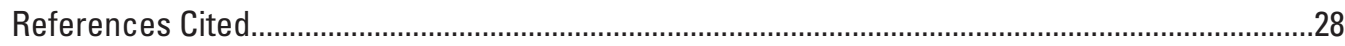

\section{Figures}

1. Map showing locations of New York City's East of Hudson reservoirs and controlled lakes, connecting channels, and aqueducts, in Westchester and Putnam Counties, New York

2. Photograph of survey boat and global navigation satellite system receivers used for the bathymetric surveys of New York City's East of Hudson reservoirs, in Westchester and Putnam Counties, New York

3. Photograph of global navigation satellite system rover receiver used to measure water surface elevation on October 27, 2017, at Bog Brook Reservoir in Putnam County, New York

4. Photograph of installation of pressure transducer used to measure water surface elevation on May 23, 2017, at Lake Gilead in Putnam County, New York.............6

5. Graphs showing sound velocity profiles for New York City's East of Hudson reservoirs and controlled lakes, in Westchester and Putnam Counties, New York.........8

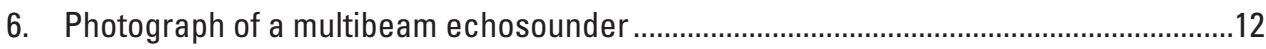

7. Photograph of bathymetry data collection with acoustic Doppler current profiler on October 23, 2019, at East Branch Reservoir...................................................14

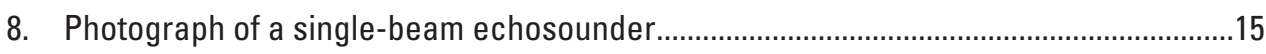

9. Maps showing example of interpolation between multibeam echosounder data and light detection and ranging data with and without estimated points for bathymetry measurements in New York City's East of Hudson reservoirs and controlled lakes, in Westchester and Putnam Counties, New York... 
10. Results of bathymetric mapping of Amawalk Reservoir in Westchester County, New York.

11. Results of bathymetric mapping of Bog Brook Reservoir in Putnam County, New York

12. Results of bathymetric mapping of Boyd Corners Reservoir in Putnam County, New York

13. Results of bathymetric mapping of Cross River Reservoir in Westchester County, New York

14. Results of bathymetric mapping of Croton Falls Reservoir in Putnam County, New York

15. Results of bathymetric mapping of Diverting Reservoir in Putnam County, New York...36

16. Results of bathymetric mapping of East Branch Reservoir in Putnam County, New York

17. Results of bathymetric mapping of Lake Gilead in Putnam County, New York.................38

18. Results of bathymetric mapping of Lake Gleneida in Putnam County, New York ...........39

19. Results of bathymetric mapping of Kensico Reservoir in Westchester County, New York.

20. Results of bathymetric mapping of Kirk Lake in Putnam County, New York.

21. Results of bathymetric mapping of Middle Branch Reservoir in Putnam County, New York

22. Results of bathymetric mapping of Muscoot Reservoir in Westchester County, New York

23. Results of bathymetric mapping of New Croton Reservoir in Westchester County, New York

24. Results of bathymetric mapping of Titicus Reservoir in Westchester County, New York

25. Results of bathymetric mapping of West Branch Reservoir in Putnam County, New York

\section{Tables}

1. New York City's East of Hudson reservoirs and controlled lakes, in Westchester and Putnam Counties, New York.

2. Dates and method used to survey bathymetry in New York City's East of Hudson reservoirs, in Westchester and Putnam Counties, New York

3. Summary of global navigation satellite system observations of water surface elevations at New York City's East of Hudson reservoirs and controlled lakes, in Westchester and Putnam Counties, New York.

4. Summary of sound velocity profiles measured in New York City's East of Hudson reservoirs, in Westchester and Putnam Counties, New York.

5. Summary of the velocity profiles groups used to measure bathymetry in New York City's East of Hudson reservoirs and controlled lakes, in Westchester and Putnam Counties, New York

6. Multibeam echosounder patch test and calibration computation results for bathymetry measurements in New York City's East of Hudson reservoirs and controlled lakes, in Westchester and Putnam Counties, New York. 
7. Final calibration values used to process multibeam echosounder data for bathymetry measurements in New York City's East of Hudson reservoirs and controlled lakes, in Westchester and Putnam Counties, New York......

8. Multibeam echosounder swaths recorded and points used in bathymetric mapping for New York City's East of Hudson reservoirs and controlled lakes, in Westchester and Putnam Counties, New York

9. Acoustic Doppler current profiler points used in bathymetric mapping for New York City's East of Hudson reservoirs and controlled lakes, in Westchester and Putnam Counties, New York.

10. Single-beam echosounder points used in quality assurance of bathymetric mapping for New York City's East of Hudson reservoirs and controlled lakes, in Westchester and Putnam Counties, New York

11. Summary of multibeam measurements in grid cells for New York City's East of Hudson reservoirs and controlled lakes, in Westchester and Putnam Counties, New York

12. Summary of percent of area mapped, by data source, for bathymetry measurements in New York City's East of Hudson reservoirs and controlled lakes, in Westchester and Putnam, New York

13. Summary of results of bathymetric surveys of New York City's East of Hudson reservoirs and controlled lakes, in Westchester and Putnam Counties, New York

14. Reservoir area and capacity at specified elevations for New York City's East of Hudson reservoirs and controlled lakes, in Westchester and Putnam Counties, New York

15. Accuracy assessment of elevations of single-beam echosounder quality assurance points compared with mapped raster surfaces for bathymetric surveys of New York City's East of Hudson reservoirs and controlled lakes, in Westchester and Putnam Counties, New York

16. Accuracy assessment of elevations of single-beam echosounder quality assurance points compared with mapped raster surfaces, categorized by slope, for bathymetric surveys of New York City's East of Hudson reservoirs and controlled lakes, in Westchester and Putnam Counties, New York

17. Accuracy assessment of computed capacity at spillway elevation for bathymetric surveys of New York City's East of Hudson reservoirs and controlled lakes, in Westchester and Putnam Counties, New York

18. Accuracy assessment of elevations of GNSS points compared with mapped raster surfaces for Boyd Corners Reservoir

19. Accuracy assessment of elevations of lidar points compared with mapped raster surfaces and single-beam echosounder points at Bog Brook and East Branch Reservoirs in Putnam County, New York

20. Accuracy assessment of elevations of lidar points compared with mapped multibeam raster cells and single-beam echosounder points, categorized by slope, at Bog Brook and East Branch Reservoirs in Putnam County, New York 


\section{Conversion Factors}

U.S. customary units to International System of Units

\begin{tabular}{lll}
\hline \multicolumn{1}{c}{ Multiply } & By & \multicolumn{1}{c}{ To obtain } \\
\hline foot $(\mathrm{ft})$ & 0.3048 & meter $(\mathrm{m})$ \\
mile $(\mathrm{mi})$ & 1.609 & kilometer $(\mathrm{km})$ \\
acre & 0.4047 & hectare $(\mathrm{ha})$ \\
square mile $\left(\mathrm{mi}^{2}\right)$ & 2.590 & square kilometer $\left(\mathrm{km}^{2}\right)$ \\
gallon (gal) & 3.785 & liter $(\mathrm{L})$ \\
million gallons $(\mathrm{Mgal})$ & 3,785 & cubic meter $\left(\mathrm{m}^{3}\right)$ \\
acre-foot (ac-ft) & 1,233 & cubic meter $\left(\mathrm{m}^{3}\right)$ \\
\hline
\end{tabular}

Temperature in degrees Celsius $\left({ }^{\circ} \mathrm{C}\right)$ may be converted to degrees Fahrenheit $\left({ }^{\circ} \mathrm{F}\right)$ as follows: ${ }^{\circ} \mathrm{F}=\left(1.8 \times{ }^{\circ} \mathrm{C}\right)+32$.

Temperature in degrees Fahrenheit $\left({ }^{\circ} \mathrm{F}\right)$ may be converted to degrees Celsius $\left({ }^{\circ} \mathrm{C}\right)$ as follows: ${ }^{\circ} \mathrm{C}=\left({ }^{\circ} \mathrm{F}-32\right) / 1.8$.

\section{Datums}

Vertical coordinate information is referenced to the North American Vertical Datum of 1988 (NAVD 88).

Horizontal coordinate information is referenced to the North American Datum of 1983 (NAD 83).

Elevation, as used in this report, refers to distance above the vertical datum.

\section{Abbreviations}

$\begin{array}{ll}\text { ADCP } & \text { acoustic Doppler current profiler } \\ \text { EOH } & \text { East of Hudson } \\ \text { GIS } & \text { geographic information system } \\ \text { GNSS } & \text { global navigation satellite system } \\ \text { INS } & \text { inertial navigation system } \\ \text { lidar } & \text { light detection and ranging } \\ \text { NSSDA } & \text { National Standard for Spatial Data Accuracy } \\ \text { NYCDEP } & \text { New York City Department of Environmental Protection } \\ \text { POS MV } & \text { Position Orientation Solution for Marine Vessels } \\ \text { RTK } & \text { real-time kinematic } \\ \text { RMSE } & \text { root mean square error } \\ \text { TIN } & \text { triangulated irregular network } \\ \text { USGS } & \text { U.S. Geological Survey } \\ \text { VRS } & \text { virtual reference station network } \\ \text { WOH } & \text { West of Hudson }\end{array}$




\title{
Bathymetry of New York City's East of Hudson Reservoirs and Controlled Lakes, 2017 to 2019
}

\author{
By Elizabeth A. Nystrom, Courtney J. Huston, and Robert J. Welk
}

\section{Abstract}

New York City maintains an extensive system of reservoirs and aqueducts to provide drinking water to its residents, including 16 reservoirs and controlled lakes in Westchester and Putnam Counties in southern New York, east of the Hudson River (also called "East of Hudson reservoirs and controlled lakes"). These reservoirs were put into service from 1842 to 1915 , and their capacities have likely changed since their original construction. To provide updated bathymetric surface, contour, and capacity data, the U.S. Geological Survey, in cooperation with New York City Department of Environmental Protection, surveyed the bathymetry of the 16 East of Hudson reservoirs and controlled lakes from 2017 to 2019 using a multibeam echosounder. The points measured with the multibeam echosounder were combined with light detection and ranging data to generate 3.28-foot raster grids of the bathymetric surfaces, bathymetric contours at 2-foot intervals of elevation, and elevation-area-capacity tables. The results of the bathymetric survey show that the East of Hudson reservoirs range from about 25 feet deep (Kirk Lake) to about 162 feet deep (Kensico Reservoir) and have a total capacity of 142.9 billion gallons, with a combined surface area of more than 11,600 acres.

The accuracy of the mapped bathymetric data was evaluated using quality assurance datasets collected with a singlebeam echosounder; about 284,000 quality assurance points were spatially joined with the mapped raster surface to compute measurement errors. The calculated mean point elevation error for the East of Hudson reservoirs was 0.35 foot, the median error was 0.21 foot, and the 95 -percent accuracy was 1.68 feet; the 95-percent accuracy of the computed capacity at spillway elevation was 1.6 percent or less. The largest errors occurred in the steepest areas of the reservoirs and in areas where the data were interpolated. Geospatial files of the bathymetry data, including mapped bathymetric surfaces, contours, and capacity tables, quality assurance points, and associated metadata are available for download as part of an accompanying U.S. Geological Survey data release.

\section{Introduction}

The New York City Department of Environmental Protection (NYCDEP) maintains an extensive system of reservoirs and aqueducts for water collection, storage, and transport; the City provides more than 1 billion gallons of drinking water to more than 9 million people every day (NYCDEP, 2020b). New York City maintains and uses 13 reservoirs and 3 lakes in Putnam and Westchester Counties in southern New York, east of the Hudson River (known as "East of Hudson [or EOH] reservoirs and controlled lakes"). The NYCDEP depends on bathymetric data for the daily and seasonal management of the EOH reservoirs and controlled lakes; these data include the mapped bathymetric surfaces and contours of the lakes and reservoirs and computed elevation-area-capacity tables. The bathymetric surfaces and contours are used in water-quality models and mapping applications, and the elevation-area-capacity tables are used to determine current and available reservoir storage. The bathymetry of the EOH reservoirs was initially determined from the land surface before each reservoir was built; the newest EOH reservoir was placed into service more than 100 years ago (NYCDEP, 2021h), and since their initial filling, the capacity and bed morphology of the reservoirs is likely to have changed. To provide updated surface, contour, and capacity data, the U.S. Geological Survey (USGS), in cooperation with NYCDEP, surveyed the bathymetry of the $16 \mathrm{EOH}$ reservoirs and controlled lakes from 2017 to 2019 . The accuracy of the mapped bathymetric data was evaluated using quality assurance datasets collected with a single-beam echosounder; about 284,000 quality assurance points were spatially joined with the mapped raster surfaces to compute measurement errors.

\section{Purpose and Scope}

The purpose of this report is to document bathymetric survey results for New York City's 16 East of Hudson reservoirs and controlled lakes completed from May 2017 to November 2019 using a multibeam echosounder. Equipment and methods of data collection and processing are described and results, including a data accuracy assessment, are presented. 


\section{Description of Study Area}

New York City's East of Hudson reservoirs and controlled lakes (fig. 1; table 1) are in the Croton and Bronx River basins in Putnam and Westchester Counties in southern New York State, about 15 to 40 miles north of the City; the EOH reservoirs and controlled lakes form New York City's Croton Water Supply System and also include designated parts of the Catskill and Delaware Water Supply Systems. Construction of the EOH reservoirs began in 1837 at Croton Reservoir; water from Croton Reservoir was first delivered to the city in 1842 (NYCDEP, 2020a). The Croton Water Supply System was expanded with the construction of several additional reservoirs in the late 1800s (table 1), and the original Croton Reservoir was replaced with the combination of New Croton and Muscoot Reservoirs, which were placed into service in 1905 (NYCDEP, 2021j, k). The newest EOH reservoir, Kensico Reservoir, was placed into service in 1915 (NYCDEP, 2021h).

Three controlled lakes are also part of the Croton Water Supply System: Lake Gilead, Lake Gleneida, and Kirk Lake (table 1); these are lakes that the NYCDEP either owns or has the rights to withdraw water from. The Catskill and Delaware Water Supply Systems were constructed beginning in the early 1900s and contain New York City's six West of Hudson (WOH) reservoirs (not included in this report): Ashokan and Schoharie Reservoirs in the Catskill Water Supply System, and Cannonsville, Neversink, Pepacton, and Rondout Reservoirs in the Delaware Water Supply System. Aqueducts connect the $\mathrm{WOH}$ reservoirs to the $\mathrm{EOH}$ reservoirs, and as a result, three of the EOH reservoirs-Boyd Corners (NYCDEP, 2021c), Kensico (NYCDEP, 2021h), and West Branch Reservoirs (NYCDEP, 2021m) - are part of the Catskill and Delaware Water Supply Systems (table 1). The WOH reservoirs were mapped with a single-beam echosounder as part of a separate bathymetric survey from 2013 to 2015 (Nystrom, 2018).
Table 1. New York City's East of Hudson reservoirs and controlled lakes, in Westchester and Putnam Counties, New York.

[Locations of reservoirs shown on figure 1. - , not applicable]

\begin{tabular}{llcl}
\hline \multicolumn{1}{c}{ Reservoir } & \multicolumn{1}{c}{$\begin{array}{c}\text { Type of } \\
\text { waterbody }\end{array}$} & $\begin{array}{c}\text { Year } \\
\text { placed } \\
\text { into } \\
\text { service }\end{array}$ & $\begin{array}{c}\text { Water } \\
\text { supply } \\
\text { system }\end{array}$ \\
\hline Amawalk Reservoir & Reservoir & 1897 & Croton \\
Bog Brook Reservoir & Reservoir & 1892 & Croton \\
Boyd Corners Reservoir & Reservoir & 1873 & Delaware \\
Cross River Reservoir & Reservoir & 1908 & Croton \\
Croton Falls Reservoir & Reservoir & 1911 & Croton \\
Diverting Reservoir & Reservoir & 1911 & Croton \\
East Branch Reservoir & Reservoir & 1891 & Croton \\
Lake Gilead & Controlled lake & - & Croton \\
Lake Gleneida & Controlled lake & - & Croton \\
Kensico Reservoir & Reservoir & 1915 & Catskill and \\
Kirk Lake & Controlled lake & - & Croton \\
Middle Branch Reservoir & Reservoir & 1878 & Croton \\
Muscoot Reservoir & Reservoir & 1905 & Croton \\
New Croton Reservoir ${ }^{2}$ & Reservoir & 1905 & Croton \\
Titicus Reservoir & Reservoir & 1893 & Croton \\
West Branch Reservoir & Reservoir & 1895 & Delaware \\
\hline & & & \\
\hline
\end{tabular}

${ }^{1}$ Data are from New York City Department of Environmental Protection (NYCDEP, 2021a-m).

${ }^{2}$ The New Croton Reservoir is an enlargement of the Croton Reservoir, which had been placed into service in 1842 (NYCDEP, 2021k). 


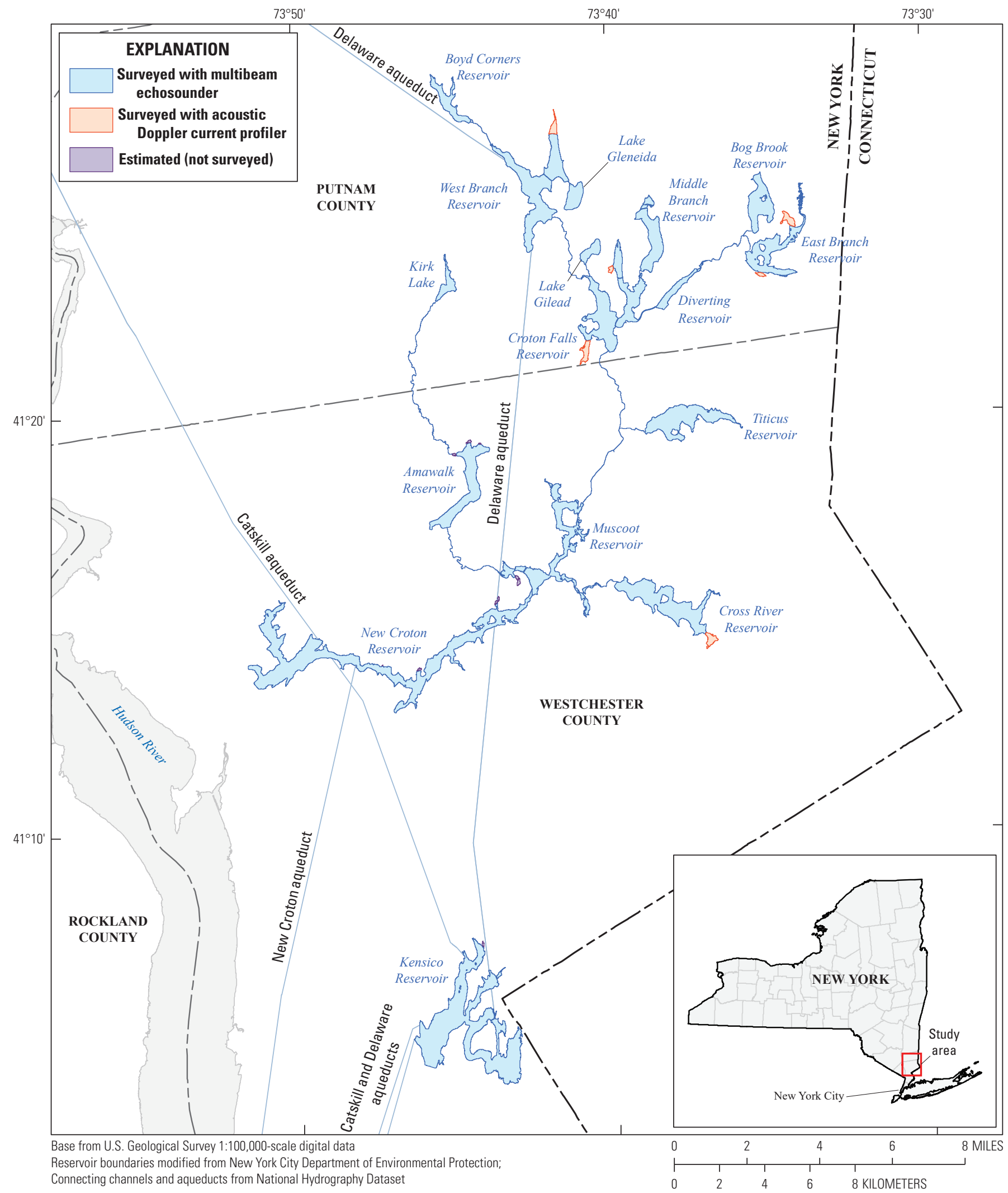

Figure 1. Map showing locations of New York City's East of Hudson reservoirs and controlled lakes, connecting channels, and aqueducts, in Westchester and Putnam Counties, New York. 


\section{Data Collection and Processing Methods}

Bathymetry in the $16 \mathrm{EOH}$ reservoirs and controlled lakes was surveyed from May 2017 to November 2019 (table 2). Data were primarily collected using a multibeam echosounder deployed from a moving boat (fig. 2). Some small areas (fig. 1) that were inaccessible with the boat used to deploy the multibeam echosounder (which required a trailer) were surveyed with an acoustic Doppler current profiler (ADCP). Quality assurance data were collected using a single-beam echosounder and compared with the multibeam echosounder dataset. Ancillary data were measured and used in processing the echosounder data and included the water surface elevation at each reservoir (for vertical position data) and sound velocity profiles. Vertical coordinate information is referenced to the North American Vertical Datum of 1988 (NAVD 88) using GEOID09. Horizontal coordinate information is referenced to the North American Datum of 1983 (NAD 83).

Table 2. Dates and method used to survey bathymetry in New York City's East of Hudson reservoirs, in Westchester and Putnam Counties, New York.

[Locations of reservoirs shown on figure 1. Survey data are available in Nystrom and others (2021). ADCP, acoustic Doppler current profiler; - , not applicable]

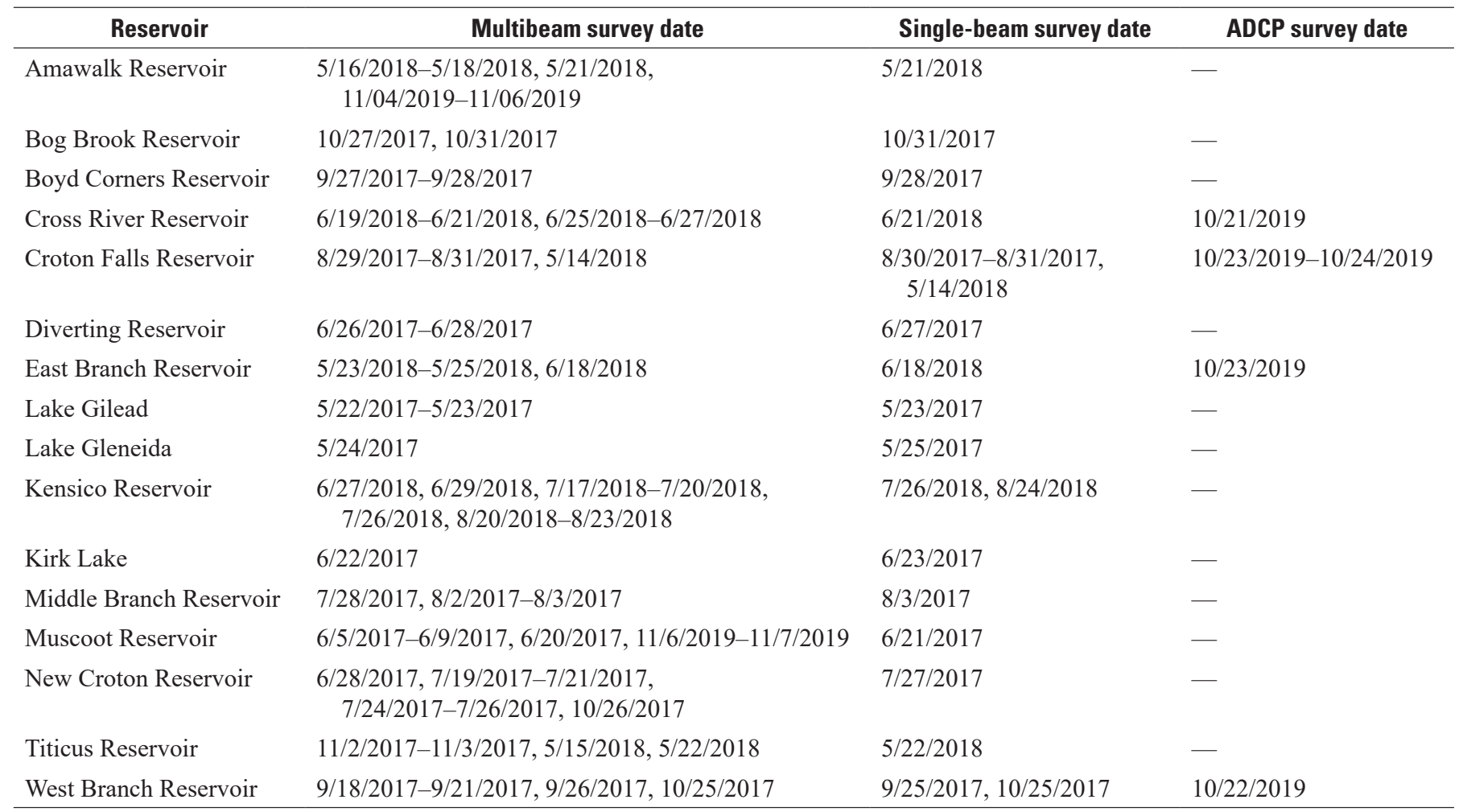

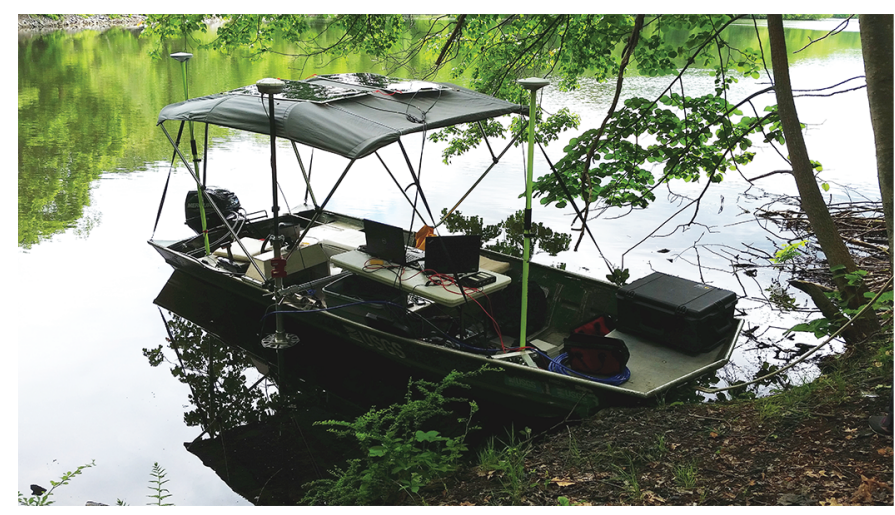

Figure 2. Photograph of survey boat and global navigation satellite system (GNSS) receivers used for the bathymetric surveys of New York City's East of Hudson reservoirs, in Westchester and Putnam Counties, New York; photograph by Elizabeth Nystrom, U.S. Geological Survey. 


\section{Vertical Control and Water Surface Elevation}

Vertical control was established at each reservoir during the bathymetric surveys using global navigation satellite system (GNSS) surveys to determine water surface elevations referenced to NAVD 88 (table 3) using a survey-grade Trimble Inc. R8 receiver (fig. 3; Trimble Inc., 2009), with a mix of static observations and real-time kinematic (RTK) observations. Static observations were postprocessed in Trimble Business Center version 5.20 (Trimble Inc., 2021); RTK observations were made using the continuously operating virtual reference station (VRS) network NYSNet operated by the New York State Department of Transportation (2021). Data about each individual GNSS observation of water surface elevations, including dilution of precision values and epochs observed, are available in Nystrom and others (2021).

Time series of water surface elevations were used to convert measured bathymetric depths to elevations referenced to NAVD 88; water surface elevation time series are available in Nystrom and others (2021). For the majority of the surveys, an unvented pressure transducer was installed in shallow water, typically near the boat ramp, on a metal post pounded solidly into the sediment (fig. 4); a second pressure transducer was installed nearby above the water surface to measure barometric pressure. A time series of the depth of the water column above the pressure transducer (corrected for water temperature and barometric pressure) was calculated for each reservoir; a time series of water surface elevation referenced to NAVD 88 was then computed using the GNSS observations of water surface elevation. A limited number of surveys were done over a short time (a few hours or less), during which the water surface elevation did not change. A constant time series of water surface elevation was generated for these surveys using the average of the GNSS observations of water surface elevation; these surveys included the ADCP surveys of small areas of Cross River, Croton Falls, East Branch, and West Branch Reservoirs and single-day, multibeam surveys of parts of West Branch Reservoir (October 25, 2017), New Croton Reservoir (October 26, 2017), and Croton Falls Reservoir (May 14, 2018).

\section{Sound Velocity}

Echosounders measure depth by transmitting a pulse of sound into the water and measuring the amount of time it takes for an echo to return; to accurately calculate depth, the sound velocity must be known. Sound velocity varies with temperature, pressure, and salinity; reservoirs are often stratified by temperature, so the sound velocity usually varies with depth. Additionally, sound velocity profiles over depth can vary by location because water in shallow areas may warm differently than in deep areas. To account for the change of sound velocity

Table 3. Summary of global navigation satellite system observations of water surface elevations at New York City's East of Hudson reservoirs and controlled lakes, in Westchester and Putnam Counties, New York.

[Locations of reservoirs shown on figure 1. Survey data are available in Nystrom and others (2021). RTK, real-time kinematic; hh:mm:ss, hour, minute, second; -, not applicable]

\begin{tabular}{|c|c|c|c|c|}
\hline Reservoir & $\begin{array}{l}\text { Number of RTK } \\
\text { observations }\end{array}$ & $\begin{array}{c}\text { Total RTK epochs } \\
\text { observed }\end{array}$ & $\begin{array}{c}\text { Number of static } \\
\text { observations }\end{array}$ & $\begin{array}{l}\text { Total duration of static observations, } \\
\text { in hh:mm:ss }\end{array}$ \\
\hline Amawalk Reservoir & 13 & 5,136 & 7 & $10: 42: 25$ \\
\hline Boyd Corners Reservoir & 4 & 2,363 & 0 & - \\
\hline Cross River Reservoir & 14 & 2,519 & 9 & $2: 31: 52$ \\
\hline East Branch Reservoir & 8 & 7,703 & 3 & 4:11:04 \\
\hline Lake Gilead & 2 & 1,410 & 0 & - \\
\hline Lake Gleneida & 3 & 1,120 & 0 & - \\
\hline Kensico Reservoir & 24 & 15,868 & 4 & $11: 46: 39$ \\
\hline New Croton Reservoir & 16 & 5,269 & 0 & - \\
\hline Titicus Reservoir & 8 & 3,171 & 3 & $9: 54: 17$ \\
\hline West Branch Reservoir & 15 & 7,778 & 1 & $2: 17: 44$ \\
\hline Total & 144 & 68,506 & 34 & $46: 20: 11$ \\
\hline
\end{tabular}




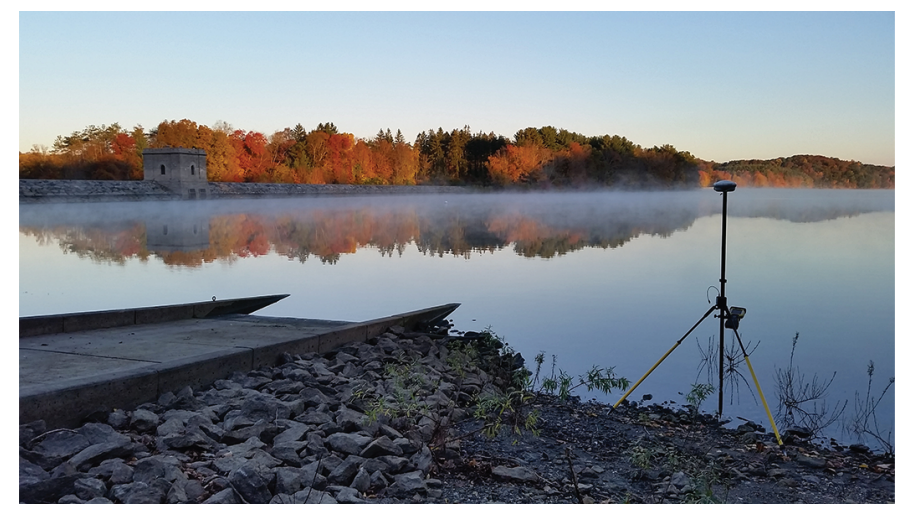

Figure 3. Photograph of global navigation satellite system (GNSS) rover receiver used to measure water surface elevation, referenced to North American Vertical Datum of 1988 (NAVD 88), on October 27, 2017, at Bog Brook Reservoir in Putnam County, New York; photograph by Elizabeth Nystrom, U.S. Geological Survey.

over depth and area, profiles were measured at various locations at each lake or reservoir using an AML Oceanographic Smart SV sensor (AML Oceanographic, 2010).

Sound velocity profiles were measured at least once per day, and usually several times during each day, especially when data were collected in different areas of a reservoir (for example, shallow inlet bays and deep areas near dams). Sound velocity was recorded at 5 -foot (ft) increments from the surface to the deepest depth possible at the location of measurement; the full depth at each location was measured unless the depth exceeded the length of the cable attached to the sound velocity probe (about $150 \mathrm{ft}$ ) or under very windy conditions that did not allow the cable of the sound velocity probe to hang vertically in the water. The cable was marked to indicate the depth of the probe, so if the cable was not vertical, the indicated depth would be higher than the actual depth of the probe. In breezy conditions, the boat motor was used to hold the position of the boat in place so the sound velocity probe cable could remain vertical. As a quality assurance check, water temperature at the reservoir surface was also measured with a thermistor during each sound velocity profile. A total of 235 individual sound velocity profiles were measured during the survey of the East of Hudson reservoirs (table 4). These individual measured sound velocity profiles were plotted and visually examined (fig. 5); where similar, profiles were grouped by date and location within a reservoir to generate average profiles for the reservoir. A total of 58 average profiles were computed for application to echosounder data (table 5). The measured and averaged sound velocity profiles used are available in Nystrom and others (2021).

\section{Multibeam Echosounder}

A multibeam echosounder uses sound to measure water depths at many locations simultaneously along a line (also called a swath) perpendicular to the echosounder. Multibeam

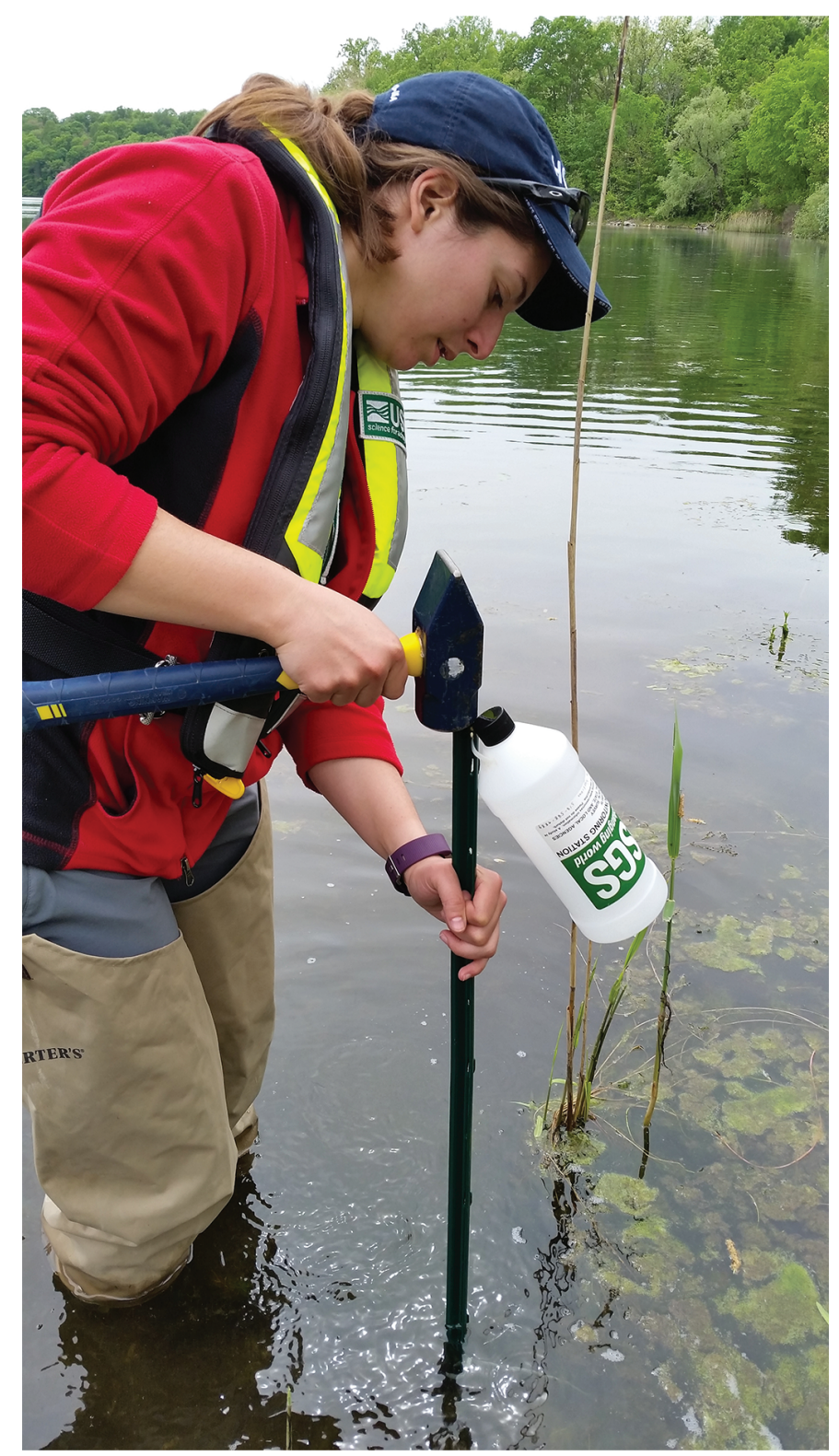

Figure 4. Photograph of installation of pressure transducer used to measure water surface elevation on May 23, 2017, at Lake Gilead in Putnam County, New York; photograph by Elizabeth Nystrom, U.S. Geological Survey.

echosounders are manufactured in many configurations, but they often use two phased-array transducers to shape acoustic transmit and receive beams and slice the acoustic returns into hundreds of individual depth measurements along each swath. To accurately map the depth measurements in space, multibeam echosounders are used with an inertial navigation system (INS) to measure the heave, pitch, roll, heading, and position of the echosounder. Multibeam echosounders and examples of their use for surveying rivers and lakes are described in Huizinga (2016) and Huizinga and Heimann (2018). 
Table 4. Summary of sound velocity profiles measured in New York City's East of Hudson reservoirs, in Westchester and Putnam Counties, New York.

[Locations of reservoirs shown on figure 1. Survey data are available in Nystrom and others (2021)]

\begin{tabular}{lcc}
\hline Reservoir & $\begin{array}{c}\text { Number of } \\
\text { sound velocity } \\
\text { profiles }\end{array}$ & $\begin{array}{c}\text { Number of groups of } \\
\text { averaged profiles of } \\
\text { sound velocity }\end{array}$ \\
\hline Amawalk Reservoir & 15 & 2 \\
Bog Brook Reservoir & 6 & 2 \\
Boyd Corners Reservoir & 6 & 1 \\
Cross River Reservoir & 18 & 3 \\
Croton Falls Reservoir & 13 & 5 \\
Diverting Reservoir & 7 & 2 \\
East Branch Reservoir & 14 & 4 \\
Lake Gilead & 4 & 1 \\
Lake Gleneida & 3 & 1 \\
Kensico Reservoir & 52 & 19 \\
Kirk Lake & 8 & 1 \\
Middle Branch Reservoir & 11 & 1 \\
Muscoot Reservoir & 25 & 5 \\
New Croton Reservoir & 23 & 4 \\
Titicus Reservoir & 8 & 3 \\
West Branch Reservoir & 22 & 4 \\
Total & 235 & 58 \\
\hline
\end{tabular}

\section{Multibeam Echosounder Data Collection}

Bathymetric data were collected with a Teledyne MB2 multibeam echosounder (fig. 6; Teledyne Marine Odom Hydrographic, 2021) with an integrated Applanix Position Orientation Solution for Marine Vessels (POS MV) Wavemaster II INS (Applanix Corp., 2017) and an integrated Teledyne SVP 70 sound velocity sensor (Teledyne RESON, 2021). The MB2 has up to 256 adjustable-frequency beamsfrom 200 to 460 kilohertz $(\mathrm{kHz})$ - with up to a 140-degree $\left({ }^{\circ}\right)$ swath width and configurable beam width (nominal beam width $1.8^{\circ}$ ). The multibeam echosounder data were collected from a flat-bottomed (jon) boat (fig. 2), between May 22, 2017, and November 7, 2019 (table 2). Primary multibeam data were collected during 2017 and 2018, but Amawalk and Muscoot Reservoirs were revisited in late 2019 to collect additional data.

The MB2 echosounder data were displayed and recorded using Teledyne PDS software (Teledyne PDS, 2019, 2021a, b) version 4.1.5.3 in 2017 and version 4.3.0.1 in 2018 and 2019. PDS creates a raster grid of raw measured depths in real time; this raster grid was used by the boat driver to navigate for the most complete coverage of the bathymetric surface possible. Data from adjacent MB2 measurement swaths were generally spaced to overlap at the edges by 10 to 25 percent; these overlapping areas were used as an additional quality assurance check during processing to verify reproducibility of point measurements after correcting for pitch, roll, heading, and sound velocity. The MB2 was generally operated at $460 \mathrm{kHz}$ with 256 beams and $140^{\circ}$ swath width, but in some areas, changes to the configuration of the MB2 were made because of field conditions. For example, in areas of excessive aquatic plant growth, the frequency of the MB2 was lowered to $200 \mathrm{kHz}$ for a stronger reflection from the bottom of the reservoir. The minimum depth measurable with the MB2 was approximately $2 \mathrm{ft}$, and the maximum depth recorded by the MB2 was about $162 \mathrm{ft}$, at Kensico Reservoir. Some areas with especially dense aquatic weeds could not be measured with the MB2 because an acoustic return from the reservoir bottom could not be detected and the vegetation obstructed the sound velocity sensor. The mapping process for these areas is described in the "Bathymetric Map Creation" section of this report.

The position data from the Wavemaster II INS was supplemented with GNSS position data from a Trimble Inc. R8 GNSS receiver positioned directly above the echosounder transducer. The R8 GNSS receiver was operated in real-time kinematic mode via the NYSNet VRS over cellular modem whenever possible; some data were recorded in stand-alone or differential GNSS mode, typically because of poor cellular data reception. Position and depth data were synchronized using the \$GPZDA string output by the R8 receiver. The \$GPZDA string, which logs the Coordinated Universal Time (UTC) date and time, is defined by the National Marine Electronics Association 0183 standard (NMEA 0183) and contains a time stamp associated with a pulse-per-second signal (National Marine Electronics Association, 2002). In cases where RTK GNSS from the R8 receiver was not available or not consistently available (for example, due to poor cellular data connection) the position and depth data were not synchronized in the field. These data were processed after collection (postprocessing) to estimate a latency duration (within a few tenths of a second) to shift position data to match depth data. High grid-cell standard deviation values (available as geospatial data in Nystrom and others, 2021) reflect these poor synchronization conditions for areas measured with more than one pass of multibeam echosounder data (for example, in the large bay on the northern side of New Croton Reservoir near the spillway).

\section{Multibeam Echosounder Data Processing}

The multibeam echosounder data were processed using PDS version 4.3.7.5 (Teledyne PDS, 2021a, b). Multibeam echosounder processing included correction for changes in sound velocity over depth, conversion from depth to elevation above NAVD 88, application of INS calibration values, and editing to remove erroneous points or spikes.

The individually measured sound velocity profiles were averaged to form group profiles for correction of the multibeam echosounder data ("Sound Velocity" section of this report; table 5). The corrections of the multibeam echosounder 

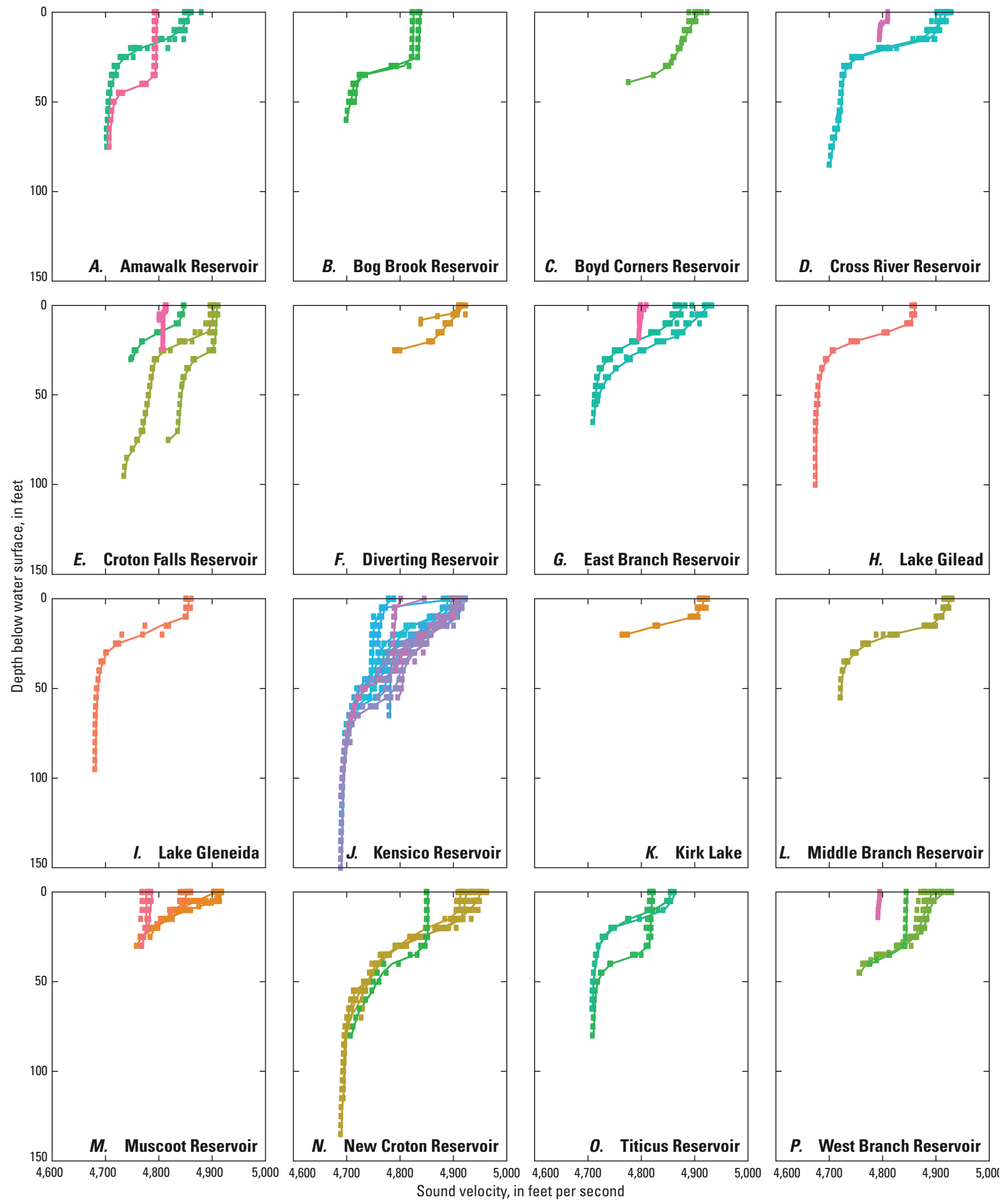

Figure 5. Graphs showing sound velocity profiles for New York City's East of Hudson reservoirs and controlled lakes, in Westchester and Putnam Counties, New York. 


\section{EXPLANATION}

Sound velocity, average group profile-Circles (data points) are individual observations; lines are average profiles. Profile groups listed in table 5 of this report

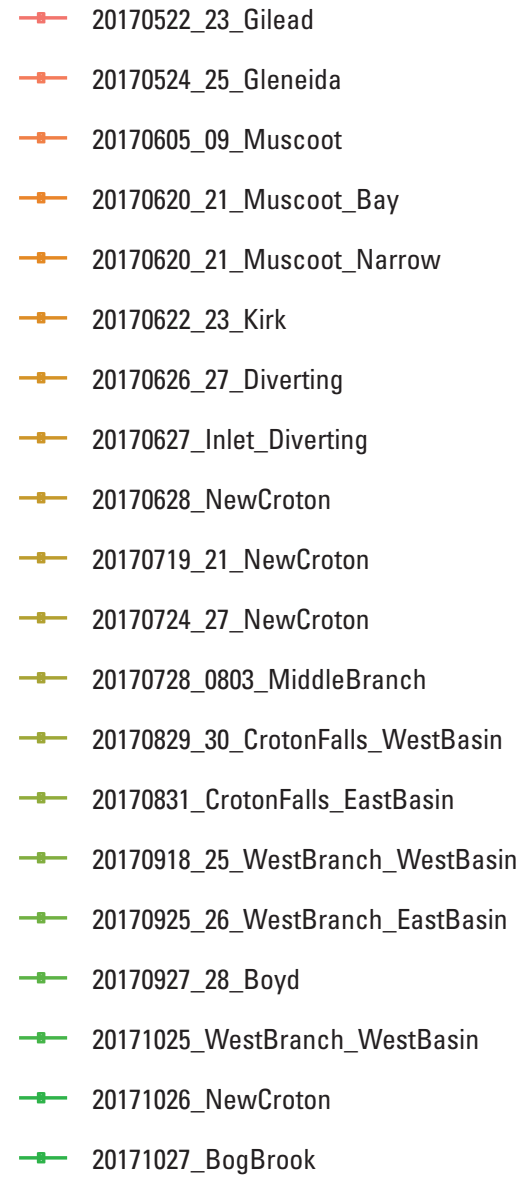

Figure 5.-Continued

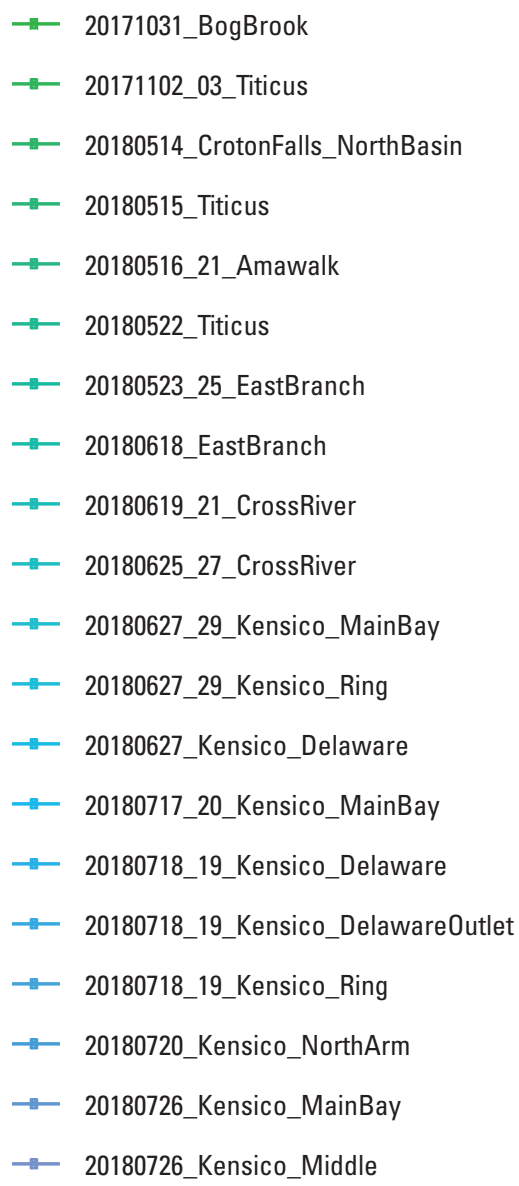

$\longleftarrow$ 20171031_BogBrook

$\simeq$-20171102_03_Titicus

$\because$ 20180514_CrotonFalls_NorthBasin

$\square$ 20180515_Titicus

$\llbracket$ 20180516_21_Amawalk

$\square$ 20180522_Titicus

$\simeq$ 20180523_25_EastBranch

$\simeq$ 20180618_EastBranch

$=$-20180619_21_CrossRiver

$\simeq$-20180625_27_CrossRiver

— 20180627_29_Kensico_MainBay

-_ 20180627_29_Kensico_Ring

$\square$-20180627_Kensico_Delaware

$\square$ 20180717_20_Kensico_MainBay

$=$ 20180718_19_Kensico_Delaware

$\simeq$-20180718_19_Kensico_Delaware0utlet

$\simeq$ 20180718_19_Kensico_Ring

$\square$-20180720_Kensico_NorthArm

— 20180726_Kensico_MainBay

$\simeq$ _20180726_Kensico_Middle

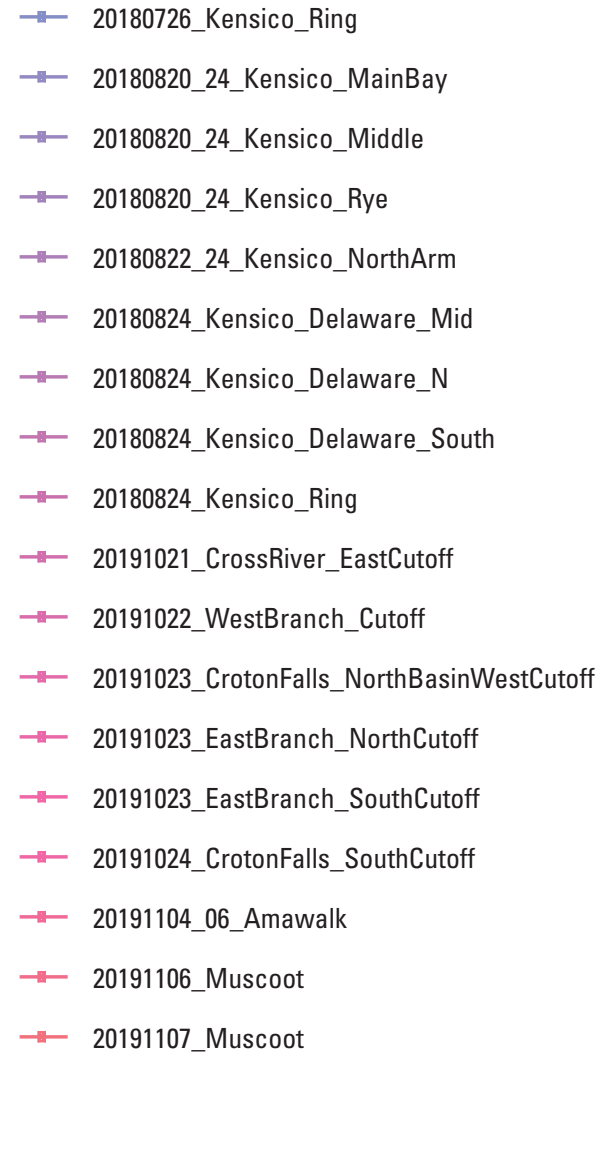

data for sound velocity included re-computation of depth from the measured acoustic pulse travel time using the vertical profile of sound velocity, rather than just the surface sound velocity, and re-mapping the placement of individual point measurements relative to the echosounder to compensate for refraction of the acoustic beams as they traveled through layers of water with different sound velocities. During data collection with the multibeam echosounder, sound velocity was also measured near the surface with the SVP 70. PDS was used to combine the time series of measurements of sound velocity at the surface with the average sound velocity profile over depth to form a time series of sound velocity profiles and apply corrections to the measured points. At many reservoirs, only one average sound velocity profile was needed if data were collected over a short period of time and the shape of the reservoir created a consistent profile of sound velocity.
Multiple average sound velocity profiles were required when data were collected over a long period of time or when the reservoir contained areas of water largely physically disconnected from each other, for example by road causeways (for example, Croton Falls Reservoir) or by reservoir geometry (for example, Kensico Reservoir).

Depths measured by the MB2 were converted to elevations above NAVD 88 using the water surface elevation as a reference. A moving average of the time series of the water surface elevation at the pressure transducer (recorded at 15 -minute intervals) was computed using a 1-hour-and15-minute- (five-observation)-centered window to remove noise (for example, from waves near the pressure transducer) from the time series. Surveyed depths were then subtracted from the time series of the water surface elevation to compute bathymetric elevations. 
Table 5. Summary of the velocity profiles groups used to measure bathymetry in New York City's East of Hudson reservoirs and controlled lakes, in Westchester and Putnam Counties, New York.

[Locations of reservoirs shown on figure 1. Survey data are available in Nystrom and others (2021)]

\begin{tabular}{|c|c|c|}
\hline Sound velocity profile group & Date range & Area applied \\
\hline \multicolumn{3}{|c|}{ Amawalk Reservoir } \\
\hline Amawalk_20180516_21 & $5 / 16 / 2016-5 / 21 / 2018$ & Whole reservoir \\
\hline Amawalk_20191104_06 & $11 / 4 / 2019-11 / 6 / 2019$ & Whole reservoir \\
\hline \multicolumn{3}{|c|}{ Bog Brook Reservoir } \\
\hline BogBrook_20171027 & $10 / 27 / 2017$ & Whole reservoir \\
\hline BogBrook_20171031 & $10 / 31 / 2017$ & Whole reservoir \\
\hline \multicolumn{3}{|c|}{ Boyd Corners Reservoir } \\
\hline Boyd_20170927_28 & 9/27/2017-9/28/2017 & Whole reservoir \\
\hline \multicolumn{3}{|c|}{ Cross River Reservoir } \\
\hline CrossRiver_20180619_21 & $6 / 19 / 2018-6 / 21 / 2018$ & Main basin \\
\hline CrossRiver_20180625_27 & $6 / 25 / 2018-6 / 27 / 2018$ & Main basin \\
\hline CrossRiver_EastCutoff_20191021 & $10 / 21 / 2019$ & East cutoff of main basin \\
\hline \multicolumn{3}{|c|}{ Croton Falls Reservoir } \\
\hline CrotonFalls_WestBasin_20170829_30 & $8 / 29 / 2017-8 / 30 / 2017$ & West basin \\
\hline CrotonFalls_EastBasin_20170831 & $8 / 31 / 2017$ & East basin \\
\hline CrotonFalls_NorthBasin_20180514 & $5 / 14 / 2018$ & North basin \\
\hline CrotonFalls_NorthBasinWestCutoff_20191023 & $10 / 23 / 2019$ & West cutoff of north basin \\
\hline CrotonFalls_SouthCutoff_20191024 & $10 / 24 / 2019$ & South cutoff of west basin \\
\hline \multicolumn{3}{|c|}{ Diverting Reservoir } \\
\hline Diverting_20170626_27 & 6/26/2017-6/27/2017 & Main basin \\
\hline Diverting_20170627_Inlet & $6 / 27 / 2017$ & Inlet \\
\hline \multicolumn{3}{|c|}{ East Branch Reservoir } \\
\hline EastBranch_20180523_25 & $5 / 23 / 2018-5 / 23 / 2018$ & Main basin \\
\hline EastBranch_20180618 & $6 / 18 / 2018$ & Main basin \\
\hline Eastbranch_NorthCutoff_20191023 & $10 / 23 / 2019$ & North cutoff of main basin \\
\hline EastBranch_SouthCutoff_20191023 & $10 / 23 / 2019$ & South cutoff of main basin \\
\hline \multicolumn{3}{|c|}{ Lake Gilead } \\
\hline Gilead_20170522_23 & $5 / 22 / 2017-5 / 23 / 2017$ & Whole lake \\
\hline \multicolumn{3}{|c|}{ Lake Gleneida } \\
\hline Gleneida_20170524_25 & $5 / 24 / 2017-5 / 25 / 2017$ & Whole lake \\
\hline \multicolumn{3}{|c|}{ Kensico Reservoir } \\
\hline Kensico_Delaware_20180627 & $6 / 27 / 2018$ & Delaware tunnel inflow \\
\hline Kensico_MainBay_20180627_29 & $6 / 27 / 2018-6 / 29 / 2018$ & Main bay \\
\hline Kensico_Ring_20180627_29 & $6 / 27 / 2018-6 / 29 / 2018$ & Ring around Great Island \\
\hline Kensico_MainBay_20180717_20 & $7 / 17 / 2018-7 / 20 / 2018$ & Main bay \\
\hline Kensico_Ring_20180718_19 & $7 / 18 / 2018-7 / 19 / 2018$ & Ring around Great Island \\
\hline Kensico_DelawareOutlet_20180718_19 & $7 / 18 / 2018-7 / 19 / 2018$ & Delaware outlet channel \\
\hline Kensico_Delaware_20180718_19 & $7 / 18 / 2018-7 / 19 / 2018$ & Delaware tunnel inflow \\
\hline Kensico_NorthArm_20180720 & $7 / 20 / 2018$ & North arm \\
\hline Kensico_Ring_20180726 & $7 / 26 / 2018$ & Ring around Great Island \\
\hline Kensico_MainBay_20180726 & $7 / 26 / 2018$ & Main bay \\
\hline Kensico_Middle_20180726 & $7 / 26 / 2018$ & Bay west of Cooney Hill \\
\hline
\end{tabular}


Table 5. Summary of the velocity profiles groups used to measure bathymetry in New York City's East of Hudson reservoirs and controlled lakes, in Westchester and Putnam Counties, New York.—Continued

[Locations of reservoirs shown on figure 1. Survey data are available in Nystrom and others (2021)]

\begin{tabular}{|c|c|c|}
\hline Sound velocity profile group & Date range & Area applied \\
\hline \multicolumn{3}{|c|}{ Kensico Reservoir-Continued } \\
\hline Kensico_MainBay_20180820_24 & $8 / 20 / 2018-8 / 24 / 2018$ & Main bay \\
\hline Kensico_Rye_20180820_24 & $8 / 20 / 2018-8 / 24 / 2018$ & Rye Lake \\
\hline Kensico_Middle_20180820_24 & $8 / 20 / 2018-8 / 24 / 2018$ & Bay west of Cooney Hill \\
\hline Kensico_NorthArm_20180822_24 & $8 / 22 / 2018-8 / 24 / 2018$ & North arm \\
\hline Kensico_Delaware_N_20180824 & $8 / 24 / 2018$ & Delaware outlet channel \\
\hline Kensico_Delaware_Mid_20180824 & $8 / 24 / 2018$ & Delaware outlet channel \\
\hline Kensico_Delaware_South_20180824 & $8 / 24 / 2018$ & Delaware outlet channel \\
\hline Kensico_Ring_20180824 & $8 / 24 / 2018$ & Ring around Great Island \\
\hline \multicolumn{3}{|c|}{ Kirk Lake } \\
\hline Kirk_20170622_23 & 6/22/2017-6/23/2017 & Whole lake \\
\hline \multicolumn{3}{|c|}{ Middle Branch Reservoir } \\
\hline MiddleBranch_20170728_0803 & $7 / 28 / 2017-8 / 3 / 2017$ & Whole reservoir \\
\hline \multicolumn{3}{|c|}{ Muscoot Reservoir } \\
\hline Muscoot_20170605_09 & $6 / 5 / 2017-6 / 9 / 2017$ & Main basin \\
\hline Muscoot_Bay_20170620_21 & $6 / 20 / 2017-6 / 21 / 2017$ & Bay \\
\hline Muscoot_Narrow_20170620_21 & $6 / 20 / 2017-6 / 21 / 2017$ & Northern section of reservoir \\
\hline Muscoot_Bay_20170620_21 & $6 / 20 / 2017-6 / 21 / 2017$ & Bay \\
\hline Muscoot_20191107 & $11 / 7 / 2019$ & Main basin \\
\hline \multicolumn{3}{|c|}{ New Croton Reservoir } \\
\hline NewCroton_20170628 & $6 / 28 / 2017$ & Whole reservoir \\
\hline NewCroton_20170719_21 & $7 / 19 / 2017-7 / 21 / 2017$ & Whole reservoir \\
\hline NewCroton_20170724_27 & $7 / 24 / 2017-7 / 27 / 2017$ & Whole reservoir \\
\hline NewCroton_20171026 & $10 / 26 / 2017$ & Whole reservoir \\
\hline \multicolumn{3}{|c|}{ Titicus Reservoir } \\
\hline Titicus_20171102_03 & $11 / 2 / 2017-11 / 3 / 2017$ & Whole reservoir \\
\hline Titicus_20180515 & $5 / 15 / 2018$ & Whole reservoir \\
\hline Titicus_20180522 & $5 / 22 / 2018$ & Whole reservoir \\
\hline \multicolumn{3}{|c|}{ West Branch Reservoir } \\
\hline WestBranch_WestsBasin_20170918_25 & $9 / 18 / 2017-9 / 25 / 2017$ & West basin \\
\hline WestBranch_EastBasin_20170925_26 & 9/25/2017-9/26/2017 & East basin \\
\hline WestBranch_WestBasin_20171025 & $10 / 25 / 2017$ & West basin \\
\hline WestBranch_Cutoff_20191022 & $10 / 22 / 2019$ & East basin cutoff \\
\hline
\end{tabular}




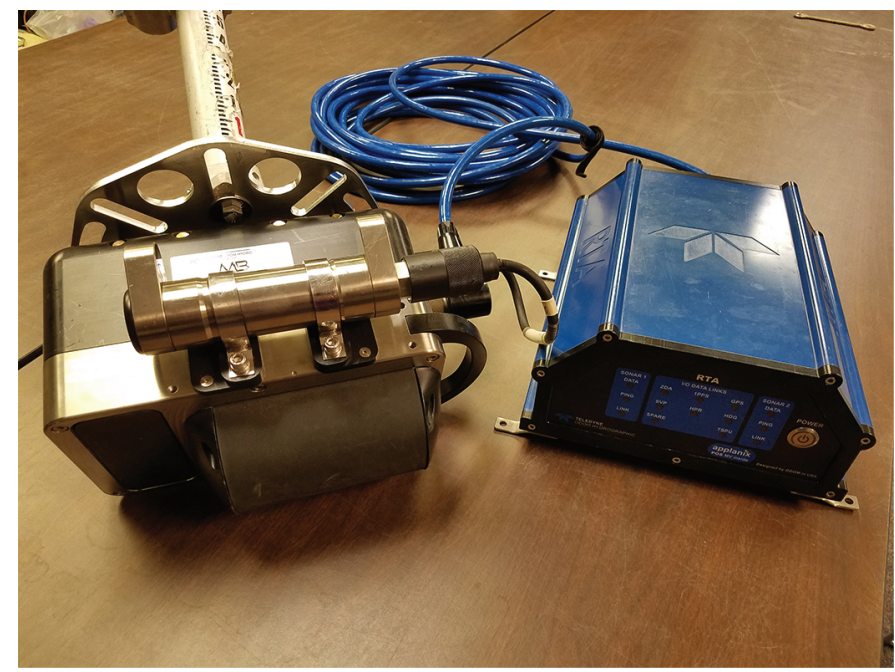

Figure 6. Photograph of a multibeam echosounder; photograph by Elizabeth Nystrom, U.S. Geological Survey.
The INS installed in the multibeam echosounder measures pitch, roll, heading, and heave to compute the correct location of the points measured by the MB2 in threedimensional space. Review of recorded heave data during processing showed large variability (sometimes more than $3 \mathrm{ft}$ ) that did not reflect the observed vertical movement of the boat during data collection, which was minimal, leading to the removal of the heave correction from the data. Vertical position data collected with RTK GNSS with good satellite constellations were examined to verify that there was no observable vertical movement of the boat while underway due to the attitude of the boat (squat or planing). To calibrate the alignment of the pitch, roll, and heading sensors of the INS to the MB2, patch tests were performed during the surveys. A patch test consists of a series of movements recorded with a multibeam echosounder over a bathymetric surface: data are collected during two passes traveling in opposite directions over a flat surface to calibrate the roll correction, then two more passes traveling in opposite directions over a slope to calibrate the pitch correction, and two final passes traveling in the same direction along offset paths over a slope to calibrate the heading correction. There were 16 patch tests (table 6), and

Table 6. Multibeam echosounder patch test and calibration computation results for bathymetry measurements in New York City's East of Hudson reservoirs and controlled lakes, in Westchester and Putnam Counties, New York.

[Locations of reservoirs shown on figure 1. Survey data are available in Nystrom and others (2021). GNSS, global navigation satellite system; RTK, real-time kinematic corrections used; GPS, stand-alone GNSS or differential GNSS; - , not used]

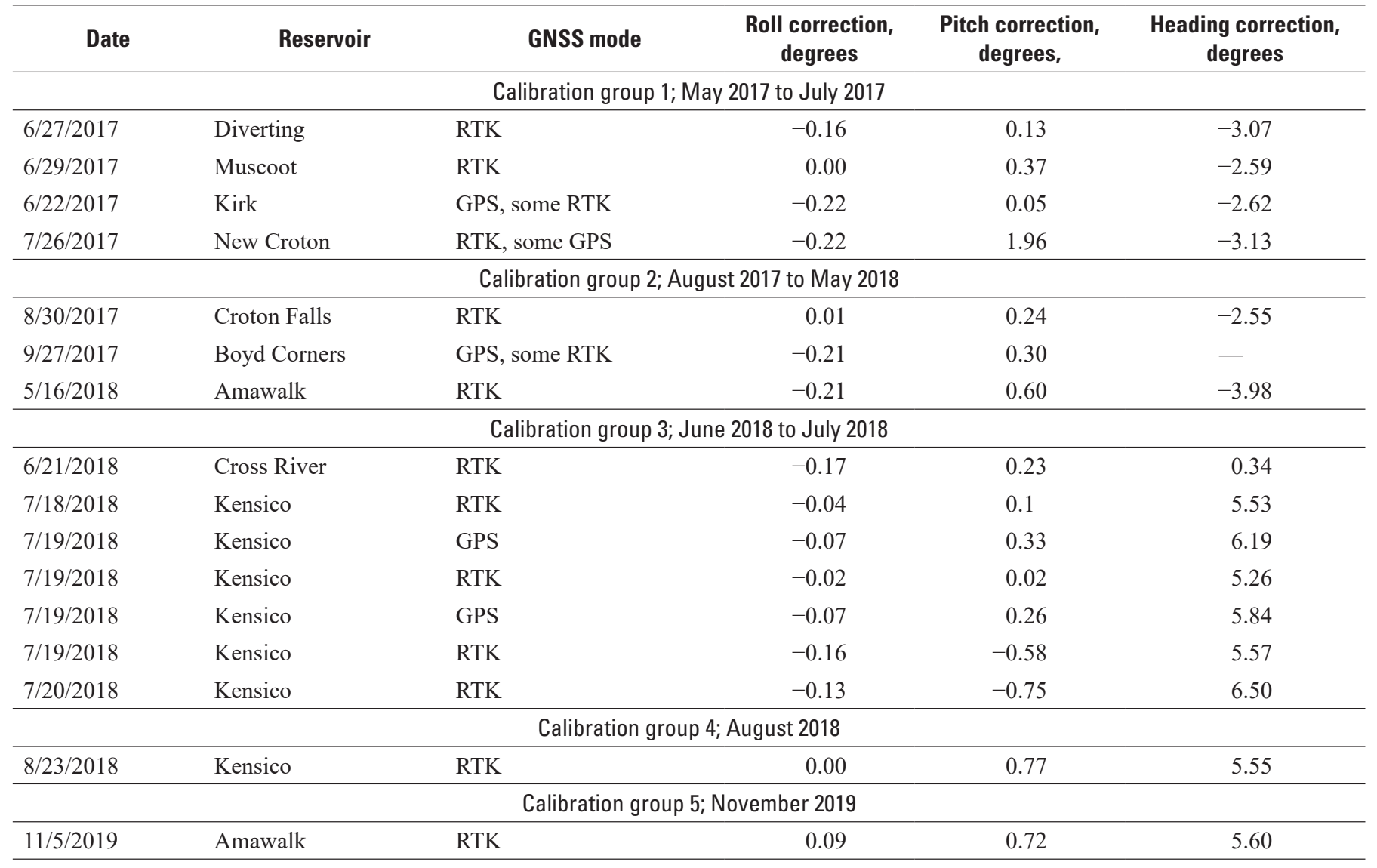


calibration values were calculated. The largest changes over time were to the calibrated heading corrections; some of these changes over time may have been due to small movements of the poles that the INS GNSS receivers were mounted on, resulting in changes to the GNSS receiver positions relative to the multibeam echosounder and INS. The patch test calibrations were then grouped into five date ranges, and average values of roll, pitch, and heading corrections were computed for each group.

The average group calibration values were applied to the MB2 data based on the date the MB2 data were collected. The results of the calibration fit were evaluated by examining the standard deviation of point values within grid cells; in some cases, the calibration results from an individual calibration were applied if the calibration results improved the alignment of the data points for the reservoir. In four of the reservoirs (table 7), a calibration value was hand-adjusted to better align data points based on overall improvement of the data for the reservoir; the multibeam echosounder data are most sensitive to adjustment of roll calibration, and this was usually the value that was adjusted. The final INS calibration values were used to process the multibeam echosounder data (table 7).

After correction for sound velocity, conversion to elevation, and calibration for heading, pitch, and roll, point data collected by the multibeam echosounder were edited to remove erroneous data and spikes. Point editing in PDS uses filters and manual editing. Filters use metadata about each return and the surrounding points and surface to identify spikes and points of poor quality, which are then reviewed and removed. Manual editing was largely used to remove points recorded above the reservoir bottom when the acoustic signal was reflected off aquatic plants.

The MB2 recorded more than 20 million swaths (each a single observation in time with up to 256 point observations) in the $\mathrm{EOH}$ reservoirs and controlled lakes (table 8), for a total of more than 5 billion points. About 28 percent of those points were rejected by filters and editing, including many in areas of dense aquatic plant growth, resulting in a total of almost 3.7 billion valid point observations after editing. A larger

Table 7. Final calibration values used to process multibeam echosounder data for bathymetry measurements in New York City's East of Hudson reservoirs and controlled lakes, in Westchester and Putnam Counties, New York.

[Locations of reservoirs shown on figure 1. Survey data are available in Nystrom and others (2021). avg, average group calibration; indiv, individual calibration; adj, calibration adjusted based on local reservoir data]

\begin{tabular}{|c|c|c|c|c|c|}
\hline Reservoir & Date range & $\begin{array}{l}\text { Roll correc- } \\
\text { tion, degrees }\end{array}$ & $\begin{array}{l}\text { Pitch correc- } \\
\text { tion, degrees, }\end{array}$ & $\begin{array}{c}\text { Heading } \\
\text { correction, } \\
\text { degrees }\end{array}$ & Notes \\
\hline \multirow[t]{2}{*}{ Amawalk Reservoir } & May 2018 & -0.14 & 0.38 & -3.27 & Group 2 avg \\
\hline & November 2019 & 0.09 & 0.72 & 5.60 & Group 5 \\
\hline Bog Brook Reservoir & October 2017 & 0.05 & 0.38 & -3.27 & Group 2 adj \\
\hline Boyd Corners Reservoir & September 2017 & -0.14 & 0.38 & -3.27 & Group 2 avg \\
\hline \multirow[t]{2}{*}{ Croton Falls Reservoir } & August 292017 & 0.03 & 0.32 & -0.50 & Indiv adj \\
\hline & August 30, 2017; May 2018 & 0.01 & 0.24 & -2.55 & Indiv \\
\hline Diverting Reservoir & June 2017 & -0.16 & 0.13 & -3.07 & Indiv \\
\hline East Branch Reservoir & May 2018 & -0.14 & 0.38 & -3.27 & Group 2 avg \\
\hline \multirow[t]{2}{*}{ Kensico Reservoir } & June and July 2018 & -0.09 & -0.06 & 5.03 & Group 3 avg \\
\hline & August 2018 & 0.00 & 0.77 & 5.55 & Indiv \\
\hline Kirk Lake & June 2017 & -0.22 & 0.05 & -2.62 & Indiv \\
\hline Middle Branch Reservoir & July and August 2017 & -0.15 & 0.63 & -2.85 & Group 1 avg \\
\hline \multirow[t]{2}{*}{ Muscoot Reservoir } & June 2017 & -0.15 & 0.63 & -2.85 & Group 1 avg \\
\hline & November 2019 & -0.15 & 0.72 & 5.60 & Indiv adj \\
\hline \multirow[t]{2}{*}{ New Croton Reservoir } & June and July 2017 & -0.15 & 0.63 & -2.85 & Group 1 avg \\
\hline & October 2017 & -0.14 & 0.38 & -3.27 & Group 2 avg \\
\hline Titicus Reservoir & November 2017; May 2018 & 0.05 & 0.38 & -3.27 & Group 2 adj \\
\hline
\end{tabular}


Table 8. Multibeam echosounder swaths recorded and points used in bathymetric mapping for New York City's East of Hudson reservoirs and controlled lakes, in Westchester and Putnam Counties, New York.

[Locations of reservoirs shown on figure 1. Survey data are available in Nystrom and others (2021)]

\begin{tabular}{lrrc}
\hline \multicolumn{1}{c}{ Reservoir } & $\begin{array}{c}\text { Swaths } \\
\text { recorded }\end{array}$ & $\begin{array}{c}\text { Valid points } \\
\text { after editing }\end{array}$ & $\begin{array}{c}\text { Percent } \\
\text { of } \\
\text { possible } \\
\text { points } \\
\text { used }\end{array}$ \\
\hline Amawalk Reservoir & $1,241,742$ & $212,039,627$ & 67 \\
Bog Brook Reservoir & 500,215 & $109,839,383$ & 86 \\
Boyd Corners Reservoir & 548,985 & $111,592,773$ & 79 \\
Cross River Reservoir & $1,905,259$ & $389,341,968$ & 80 \\
Croton Falls Reservoir & 995,318 & $198,127,567$ & 78 \\
Diverting Reservoir & 512,755 & $102,209,977$ & 78 \\
East Branch Reservoir & $1,059,104$ & $232,173,137$ & 86 \\
Lake Gilead & 271,163 & $23,279,236$ & 34 \\
Lake Gleneida & 463,824 & $44,934,534$ & 38 \\
Kensico Reservoir & $3,189,588$ & $634,632,623$ & 78 \\
Kirk Lake & 876046 & $185,196,539$ & 83 \\
Middle Branch & 613,975 & $126,155,198$ & 80 \\
$\quad$ Reservoir & & & 61 \\
Muscoot Reservoir & $2,472,702$ & $388,065,707$ & 61 \\
New Croton Reservoir & $2,345,130$ & $400,057,133$ & 67 \\
Titicus Reservoir & $1,102,892$ & $167,477,387$ & 59 \\
West Branch Reservoir & $1,914,853$ & $367,962,147$ & 75 \\
\cline { 2 - 4 } Total & $20,013,551$ & $3,693,084,936$ & 72 \\
\hline & & & \\
\hline
\end{tabular}

percentage of points than the average for all EOH reservoirs and controlled lakes were removed in some reservoirs mainly due to aquatic plant growth conditions (for example, in Lake Gilead, a substantial part of the lake was filled with weedy areas).

\section{Acoustic Doppler Current Profiler}

Additional bathymetric data were collected in October 2019 in small areas of Cross River, Croton Falls, East Branch, and West Branch Reservoirs (fig. 1) because they were inaccessible with the boat used for the multibeam echosounder surveys (which required a trailer); for the additional data collection, a Teledyne RD Instruments 1,200-kHz RioPro ADCP was used (Teledyne Marine, 2016). The ADCP was deployed in a small trimaran tethered to a small manned boat powered with an electric trolling motor (fig. 7) and deployed by hand. The additional data were reviewed using Teledyne

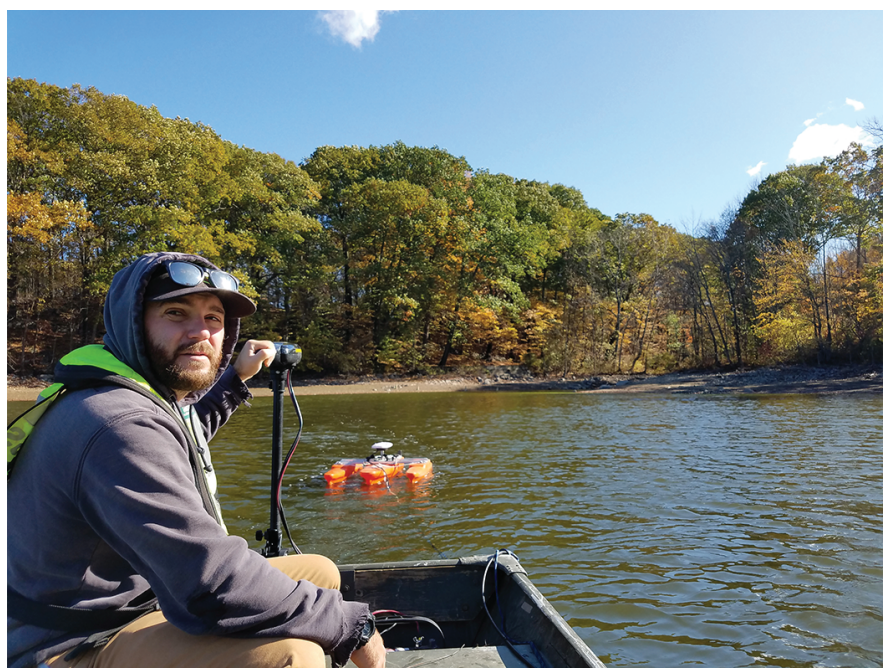

Figure 7. Photograph of bathymetry data collection with acoustic Doppler current profiler on October 23, 2019, at East Branch Reservoir in Putnam County, New York; photograph by Elizabeth Nystrom, U.S. Geological Survey.

RD Instruments WinRiver II version 2.18 (Teledyne Marine, 2020). The built-in self-tests that are included in WinRiver II were run daily before the start of data collection, and the water temperature measured by the ADCP was verified by an independent measurement using a thermistor.

Along with the ADCP depth data, position data were collected with a Hemisphere GNSS, Inc. V102 GNSS compass (Hemisphere GNSS, Inc., 2017) using differential GNSS. Position data were output from the V102 at 2 hertz $(\mathrm{Hz})$ as NMEA 0183 \$GPGGA strings (National Marine Electronics Association, 2002) and recorded as ASCII text files using WinRiver II. Surface sound velocity was calculated by WinRiver II for each ping by using the water temperature measured by the ADCP; sound velocity profiles were measured but varied by less than 0.5 percent from surface to bottom at all sites (fig. 5, profiles in pink [shallow profiles]). Consequently, sound velocity corrections over depth were not applied. The RioPro ADCP measured four individual acoustic beam depths for each ping, each similar to a single beam echosounder measurement; for mapping, an average of the four beam depth measurements was used because the areas measured were generally shallow and not steeply sloped. Depths measured by the ADCP were converted to elevations above NAVD 88 using the water surface elevation as a reference as with the multibeam echosounder data; however, for the ADCP measurements, constant values measured with static GNSS observations were used. After conversion to elevation, each transect was screened for spikes and measurement errors. More than 48,000 ADCP points were recorded and used in processing (table 9). 
Table 9. Acoustic Doppler current profiler points used in bathymetric mapping for New York City's East of Hudson reservoirs and controlled lakes, in Westchester and Putnam Counties, New York.

[Locations of reservoirs shown on figure 1. Survey data are available in Nystrom and others (2021)]

\begin{tabular}{lc}
\hline \multicolumn{1}{c}{ Reservoir } & Valid points after editing \\
\hline Cross River Reservoir & 10,414 \\
Croton Falls Reservoir & 17,979 \\
East Branch Reservoir & 10,184 \\
West Branch Reservoir & 10,035 \\
Total & 48,612 \\
\hline
\end{tabular}

\section{Single-Beam Echosounder}

Bathymetric data were collected with a single-beam echosounder at each reservoir for use as a quality-assurance check of the mapped multibeam echosounder data. The single-beam echosounder used for this study was a SyQwest Inc. Bathy-500MF (fig. 8) survey-grade echosounder with a resolution of $0.1 \mathrm{ft}$ and a manufacturer-specified accuracy of $0.1 \mathrm{ft}$ plus 0.1 percent of the depth (SyQwest, Inc., 2008). A 200-kHz narrow-beam transducer ( $3^{\circ}$ at 3 decibels) was used; the minimum measurable depth with this configuration was approximately $3 \mathrm{ft}$. Position data were measured using the R8 GNSS receiver with VRS RTK corrections; the GNSS receiver was mounted directly above the single-beam transducer during data collection. Pitch and roll were not recorded or used in processing the single-beam echosounder data. Instead, the transducer was leveled on the boat using a bubble level attached to the transducer mount; errors in the alignment of the transducer or changes in the tilt of the boat while under way, therefore, can contribute to errors in measurement of depth with the single-beam echosounder (Nystrom and Collenburg, 2020).

Live echosounder readings and RTK GNSS positional data were integrated while in the field using HYPACK version 17.0.26.0 (HYPACK, 2021) hydrographic software, which used the NMEA 0183 \$GPZDA string to temporally synchronize position and depth data with the GNSS data. Single-beam echosounder data were collected along predetermined transects oriented at a $45^{\circ}$ angle to the main axis of the reservoir; the goal of the spacing of the transects was to record data along approximately 10 lines from edge to edge of the reservoir. The configuration of these quality assurance lines followed procedures similar to those used by Wilson and Richards (2006).

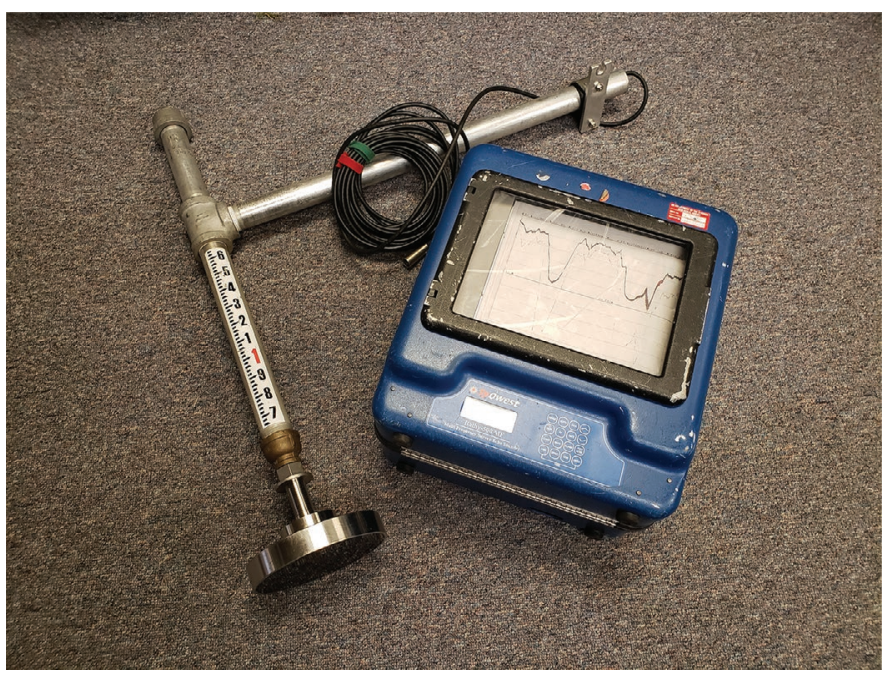

Figure 8. Photograph of a single-beam echosounder; photograph by Elizabeth Nystrom, U.S. Geological Survey.

Single-beam echosounder data were processed using HYPACK version 19.0.11.0 (HYPACK, 2021); processing included correction for changes in sound velocity over depth, conversion from depth to elevation above NAVD 88 using the water surface elevation as a reference (same process as for the multibeam echosounder data), and manual editing to remove erroneous points or spikes. The averaged sound velocity profiles applicable to the date and location of the data collection were used to process the single-beam data. Depths measured by the single-beam echosounder were converted to elevations above NAVD 88 by using the same method as was used for the multibeam echosounder data, using the water surface elevation as a reference.

After conversion to elevation, each transect was screened for spikes and measurement errors. Spikes and errors can occur in the echo sounder data in the digitization process (the process by which the echosounder determines a digital depth value from the analog echo signal received by the transducer). For example, a strong return from objects in the water column (such as debris, fish, or vegetation) can be digitized as the measured depth, or the "second" acoustic return can be digitized instead of the "first." Errors can occur because in shallow water, sound can be reflected off the water surface as well as the reservoir bottom; the "second" return travels from the echosounder to the reservoir bottom, to the water surface, to the reservoir bottom, and back to the echosounder before being digitized; therefore, the recorded value is approximately twice as deep as the actual value. After processing the singlebeam echosounder data, about 284,000 point observations remained (table 10). 
Table 10. Single-beam echosounder points used in quality assurance of bathymetric mapping for New York City's East of Hudson reservoirs and controlled lakes, in Westchester and Putnam Counties, New York.

[Locations of reservoirs shown on figure 1. Survey data are available in Nystrom and others (2021)]

\begin{tabular}{lc}
\hline \multicolumn{1}{c}{ Reservoir } & Valid points after editing \\
\hline Amawalk Reservoir & 15,271 \\
Bog Brook Reservoir & 18,711 \\
Boyd Corners Reservoir & 10,049 \\
Cross River Reservoir & 20336 \\
Croton Falls Reservoir & 27,847 \\
Diverting Reservoir & 8,845 \\
East Branch Reservoir & 20,142 \\
Lake Gilead & 5,945 \\
Lake Gleneida & 14,960 \\
Kensico Reservoir & 27,315 \\
Kirk Lake & 15,345 \\
Middle Branch Reservoir & 12,020 \\
Muscoot Reservoir & 16,808 \\
New Croton Reservoir & 18,568 \\
Titicus Reservoir & 17,669 \\
West Branch Reservoir & 33,916 \\
Total & 283,747 \\
\hline
\end{tabular}

\section{Bathymetric Map Creation}

Complete coverage of the bathymetric surface with the multibeam echosounder was not possible, especially in shallow areas near shorelines where boat navigation was limited or in areas with excessive aquatic plants. Light detection and ranging (lidar) data (NYCDEP, 2009) were used to supplement the echosounder data along reservoir shorelines and islands and to allow interpolation of elevation in shallow areas near the edge of the reservoir. Lidar data were imported into ArcMap (Esri Inc., 2020) by extracting the ground returns from the point clouds in the LAS format file for an area around the reservoir bounded by the lidar contour line closest to $10 \mathrm{ft}$ above the surveyed water surface elevation, with an additional surrounding buffer of $32.8 \mathrm{ft}$. Furthermore, all lidar data above the water surface elevation were included for islands within a given lake. The processed multibeam echosounder points were combined with ADCP data and the lidar data, and gaps were interpolated to create complete raster grid bathymetric surfaces. The raster grids were then used to create bathymetric contours and compute elevation-area-capacity tables and were compared with the quality assurance dataset. The raster grid bathymetric surfaces and contours were created in the Grid Model Editor of the PDS software (Teledyne PDS, $2019, \S 19.2$ ).
A 3.28-ft cell-size raster grid was created for each data source (multibeam echosounder, ADCP, and lidar) using the mean elevation of the points within a given raster cell; these single-source grids were then combined into a single raster grid, with multibeam echosounder data taking precedence over other data sources, and ADCP data taking precedence over lidar data. Grid cells computed using multibeam echosounder data contained an average of about 92 individual measurements of depth. The number of multibeam echosounder measurements in a given area is dependent on the water depth, the ping rate and beam geometry of the echosounder, the speed of the boat, and the overlap of successive measurement passes. In general, the echosounder can make more measurements per unit time in shallow water and a single measurement swath of points covers a smaller distance than it would in deeper water, and the overall number of multibeam echosounder measurements per cell is largely dependent on average depth. Of the EOH reservoirs and controlled lakes, Kirk Lake (which was fairly shallow) had the highest average multibeam echosounder point measurement density per grid cell (about 410; table 11) and Lake Gilead (which was fairly deep) had the lowest (about 57). Grid cells computed using lidar or ADCP data typically had one to two observations per cell.

Table 11. Summary of multibeam measurements in grid cells for New York City's East of Hudson reservoirs and controlled lakes, in Westchester and Putnam Counties, New York.

[Grid cell are 3.28-foot cells in the mapped raster grid of the bathymetric surface. Locations of reservoirs shown on figure 1. Survey data are available in Nystrom and others (2021)]

\begin{tabular}{lrcc}
\hline \multicolumn{1}{c}{ Reservoir } & $\begin{array}{c}\text { Number of } \\
\text { multibeam } \\
\text { grid cells }\end{array}$ & $\begin{array}{c}\text { Mean } \\
\text { number of } \\
\text { measure- } \\
\text { ments in } \\
\text { each cell }\end{array}$ & $\begin{array}{c}\text { Median } \\
\text { number of } \\
\text { measure- } \\
\text { ments in } \\
\text { each cell }\end{array}$ \\
\hline Amawalk Reservoir & $2,106,722$ & 100.6 & 61 \\
Bog Brook Reservoir & $1,460,609$ & 75.2 & 42 \\
Boyd Corners Reservoir & 745,916 & 149.6 & 88 \\
Cross River Reservoir & $3,323,054$ & 117.2 & 64 \\
Croton Falls Reservoir & $3,242,971$ & 61.1 & 31 \\
Diverting Reservoir & 520,343 & 196.4 & 103 \\
East Branch Reservoir & $1,878,839$ & 123.6 & 58 \\
Lake Gilead & 405,324 & 57.4 & 24 \\
Lake Gleneida & 647,544 & 69.4 & 37 \\
Kensico Reservoir & $8,293,885$ & 76.5 & 36 \\
Kirk Lake & 451,895 & 409.8 & 232 \\
Middle Branch Reservoir & $1,442,637$ & 87.4 & 54 \\
Muscoot Reservoir & $2,202,971$ & 176.2 & 126 \\
New Croton Reservoir & $7,035,332$ & 56.9 & 36 \\
Titicus Reservoir & $2,293,188$ & 73.0 & 43 \\
West Branch Reservoir & $3,906,979$ & 94.2 & 50 \\
\hline
\end{tabular}


The grid cells that did not contain any echosounder or lidar data were interpolated in the PDS Grid Model Editor (Teledyne PDS, 2019, §19.2), first using the circular interpolation function with a small interpolation radius ( 6.5 to $16.5 \mathrm{ft}$ ), and then filling the remaining larger gaps using the triangular interpolation method. The circulation interpolation routine is typically used to fill small gaps in the data; it computes an inverse-distance-weighted mean of cells within the interpolation radius (Teledyne PDS, 2019). The triangular interpolation routine creates a triangulated irregular network (also known as a TIN) to fill larger gaps in the data. An iterative process was used, in which an interpolation was run and examined; estimated points were added as necessary to create a visually reasonable interpolation.

Areas along and near structures such as dams and spillways, around submerged islands, near shorelines, and with a high density of submerged vegetation, where echosounder data could not be collected, were areas that typically required the addition of estimated points. The shape of the shoreline strongly influenced where estimated points were required; for example, estimated points were used to prevent large flat areas from being created due to triangulation connection of lidar data on opposite sides of inlet channels or shallow bays (fig. 9). The initial elevation values for estimated points in these areas were based on a linear interpolation between multibeam echosounder data and lidar data; in some cases, estimated values were drawn in to approximate the placement of an elevation contour. Some of the largest interpolation areas that required the addition of estimated points were shallow areas with a large amount of submerged vegetation where echosounder data could not be collected, for example, the many shallow bays in Muscoot Reservoir. Echosounder data were collected as far into these shallow areas as possible to characterize the slope and shape of the reservoir bottom in those parts of the area and to determine the location and depth of any channels. Many of the largest shallow weedy areas were very flat, which informed the estimation of the unmeasurable areas. Additionally, aerial orthophotographs were

\section{A. Multibeam and lidar data only}

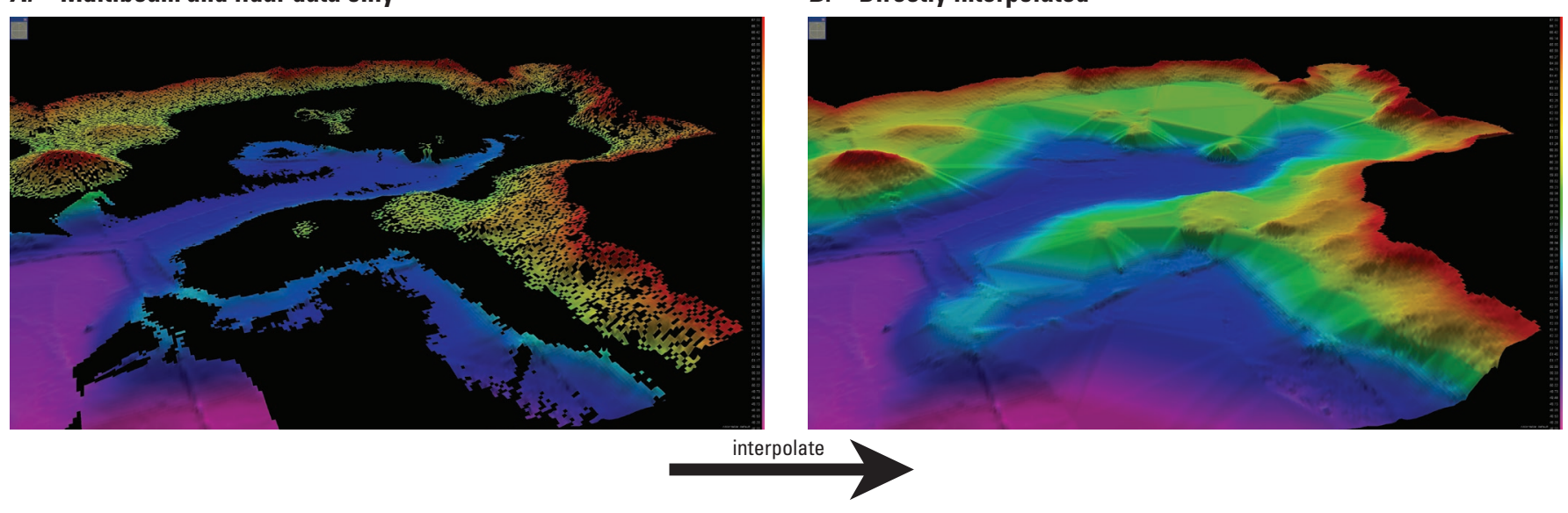

\section{B. Directly interpolated}

\section{Estimated points added}

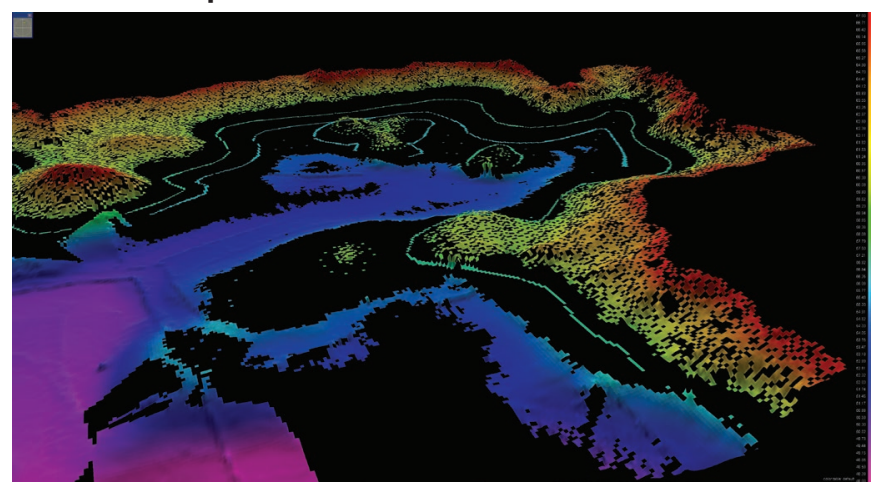

\section{Interpolated with estimated points}

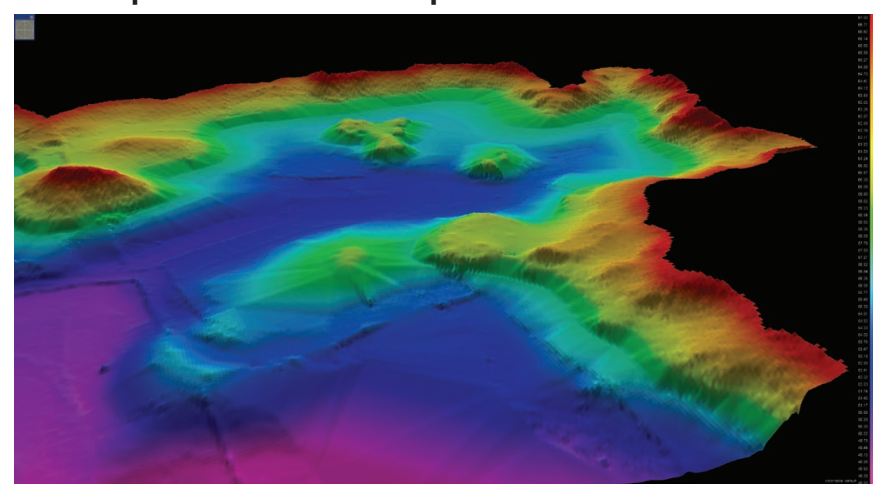

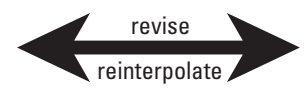

Figure 9. Maps showing example of interpolation between multibeam echosounder data and light detection and ranging (lidar) data with and without estimated points for bathymetry measurements in New York City's East of Hudson reservoirs and controlled lakes, in Westchester and Putnam Counties, New York. $A$, Multibeam and lidar data only; $B$, interpolated from multibeam and lidar data; $C$, estimated points added; and $D$, interpolated with estimated points added. Arrows indicate direction of processing step. 
used to identify the shape of submerged features and inlets, the location of extremely shallow areas, and to estimate the maximum elevation of submerged islands relative to spillway elevations.

Two additional raster grids were created for each reservoir to describe the data contained in the elevation grid: one that contains information about the source of the data used in the final elevation grid, and one that contains the standard deviation of the point elevation values within each cell. The sizes and locations for the cells in these grids were created to match those of the elevation grids. The raster grid of source data type contains an enumerated value that specified if the elevation was determined with the multibeam echosounder, ADCP, or lidar data or if it contained an estimated or interpolated value. The standard deviation grid (Nystrom and others, 2021) contains the standard deviation of observed point elevations within a cell; if a cell contained fewer than two elevation observations (for example, estimated or interpolated cells), the standard deviation for that cell could not be computed and it was left empty.

About 84 percent of the total surface area of the EOH reservoirs and controlled lakes was measured using the multibeam echosounder (table 12) and lidar data filled about 2 percent of the mapped reservoirs, requiring estimated and interpolated data for about 14 percent of the mapped reservoirs. Lidar data and interpolated cells were used to fill in the mapped area above the water surface, which was included to allow computation of reservoir capacity for elevations above spillway elevation. Lake Gleneida and Kensico Reservoir had the highest percentages of area directly measured with the multibeam echosounder ( 93 and 92 percent, respectively). Muscoot Reservoir had the lowest percentage of area directly measured with the multibeam echosounder (64 percent) and the highest percentage of estimated and interpolated area (35 percent) because of the extent of large, extremely weedy, shallow areas in the reservoir. The largest percentages of area covered with lidar data were at Diverting, East Branch, and Bog Brook Reservoirs (10, 11, and 7 percent, respectively); the water level at these three reservoirs was fairly low when the lidar data were collected, so more of the area between the shoreline and the multibeam echosounder data contained useable lidar data.

Bathymetric contours were created at 2-ft intervals of depth and elevation above NAVD 88 from the 3.28 - $\mathrm{ft}$ raster using the Grid Model Editor in PDS (Teledyne PDS, 2019, $\S 19.2$ ). A smoothing window of 4 (medium) was used, and contours less than $20 \mathrm{ft}$ long (about the length of the border of two grid cells) were removed. In some steep areas (for example, close-to-vertical dam faces or intake structures), contours were hand edited after they were created to prevent contours from crossing; along vertical structures, many contours were essentially coincident. Elevation-area-capacity tables were calculated from mapped raster surfaces in a geographic information system (GIS) using the surface volume three-dimensional analyst tool in ArcMap (Esri Inc., 2020). Capacity data were tabulated at 0.01 - $\mathrm{ft}$ intervals from about $1 \mathrm{ft}$ above the lowest mapped elevation - the lowest computed elevation was
Table 12. Summary of percent of area mapped, by data source, for bathymetry measurements in New York City's East of Hudson reservoirs and controlled lakes, in Westchester and Putnam, New York.

[Locations of reservoirs shown on figure 1. Survey data are available in Nystrom and others (2021). Percentages shown are percent of mapped reservoir area at full spillway elevation. lidar, light detection and ranging; - , not applicable; $<$, less than]

\begin{tabular}{|c|c|c|c|c|}
\hline Reservoir & $\begin{array}{l}\text { Multi- } \\
\text { beam } \\
\text { echo- } \\
\text { sounder }\end{array}$ & $\begin{array}{l}\text { Acoustic } \\
\text { Doppler } \\
\text { current } \\
\text { profiler }\end{array}$ & Lidar & $\begin{array}{c}\text { Esti- } \\
\text { mated } \\
\text { and } \\
\text { interpo- } \\
\text { lated }\end{array}$ \\
\hline Amawalk Reservoir & 88 & - & $<1$ & 12 \\
\hline Bog Brook Reservoir & 90 & - & 7 & 3 \\
\hline Boyd Corners Reservoir & 81 & - & 1 & 18 \\
\hline Cross River Reservoir & 88 & $<1$ & $<1$ & 11 \\
\hline Croton Falls Reservoir & 82 & $<1$ & 5 & 12 \\
\hline Diverting Reservoir & 85 & - & 11 & 5 \\
\hline East Branch Reservoir & 80 & $<1$ & 10 & 9 \\
\hline Lake Gilead & 88 & - & $<1$ & 11 \\
\hline Lake Gleneida & 93 & - & $<1$ & 7 \\
\hline Kensico Reservoir & 92 & - & 1 & 8 \\
\hline Kirk Lake & 88 & - & $<1$ & 12 \\
\hline $\begin{array}{l}\text { Middle Branch } \\
\text { Reservoir }\end{array}$ & 82 & - & $<1$ & 17 \\
\hline Muscoot Reservoir & 64 & - & 1 & 35 \\
\hline New Croton Reservoir & 81 & - & 1 & 19 \\
\hline Titicus Reservoir & 83 & - & $<1$ & 17 \\
\hline West Branch Reservoir & 90 & $<1$ & $<1$ & 10 \\
\hline $\begin{array}{l}\text { Overall East of } \\
\text { Hudson reservoirs } \\
\text { and controlled lakes }{ }^{1}\end{array}$ & 84 & $<1$ & 2 & 14 \\
\hline
\end{tabular}

${ }^{1}$ Totals may not equal 100 percent because of independent rounding.

chosen to result in a computed volume of about 0.01 million gallons - to $4 \mathrm{ft}$ above the spillway elevation. Capacity tables were computed for water surface elevations above spillway elevations because the water surface elevation in the reservoirs is often slightly higher than the spillway elevation when the reservoir is full and spilling and for emergency preparedness in case of flooding.

\section{Results of Bathymetric Surveys}

The results of the bathymetric surveys (figs. 10 to 25, in back of report; table 13) show that depths at New York City's EOH reservoirs and controlled lakes range from about $25 \mathrm{ft}$ (Kirk Lake) to about $162 \mathrm{ft}$ (Kensico Reservoir). At full spillway elevation, the total capacity of the $\mathrm{EOH}$ reservoirs 
Table 13. Summary of results of bathymetric surveys of New York City's East of Hudson reservoirs and controlled lakes, in Westchester and Putnam Counties, New York.

[Locations of reservoirs shown on figure 1. Expanded elevation-area-capacity table is available in Nystrom and others (2021). Values may not add to totals because of rounding. NAVD 88, North American Vertical Datum of 1988; -, not applicable]

\begin{tabular}{|c|c|c|c|c|c|}
\hline Reservoir & $\begin{array}{c}\text { Spillway elevation, } \\
\text { in feet above } \\
\text { NAVD } 88\end{array}$ & $\begin{array}{c}\text { Maximum } \\
\text { mapped depth, } \\
\text { in feet }\end{array}$ & $\begin{array}{l}\text { Total capacity at } \\
\text { spillway elevation, } \\
\text { in million gallons }\end{array}$ & $\begin{array}{c}\text { Area at spillway } \\
\text { elevation, } \\
\text { in square miles }\end{array}$ & $\begin{array}{c}\text { Area at spillway } \\
\text { elevation, } \\
\text { in acres }\end{array}$ \\
\hline Amawalk Reservoir & 398.32 & 74.37 & 6,731 & 0.9085 & 581.4 \\
\hline Bog Brook Reservoir & 415.54 & 65.17 & 4,473 & 0.6284 & 402.2 \\
\hline Boyd Corners Reservoir & 579.29 & 44.24 & 1,700 & 0.3469 & 222 \\
\hline Cross River Reservoir & 328.23 & 114.17 & 10,350 & 1.431 & 915.6 \\
\hline Diverting Reservoir & 308.11 & 35.58 & 814.3 & 0.2358 & 150.9 \\
\hline East Branch Reservoir & 415.54 & 65.16 & 5,123 & 0.9024 & 577.5 \\
\hline Lake Gilead & 492.60 & 113.74 & 1,859 & 0.1754 & 112.3 \\
\hline Lake Gleneida & 501.00 & 100.57 & 2,709 & 0.268 & 171.5 \\
\hline Muscoot Reservoir & 198.02 & 34.63 & 3,573 & 1.248 & 798.7 \\
\hline New Croton Reservoir & 194.25 & 147.01 & 28,950 & 3.282 & 2,100 \\
\hline Titicus Reservoir & 323.23 & 85.95 & 7,067 & 1.046 & 669.3 \\
\hline West Branch Reservoir & 501.92 & 52.49 & 9,987 & 1.686 & 1,079 \\
\hline Total & - & - & 142,920 & 18.181 & 11,635 \\
\hline
\end{tabular}

and controlled lakes is about 142.9 billion gallons, with a total surface area of more than 11,600 acres (tables 13 and 14). The useable capacity of each reservoir (the volume above the minimum operating level for drinking water supply) was not computed but is less than the total capacity of the reservoir. GIS files of the bathymetry data, including the mapped bathymetric surfaces, contours, and quality assurance points, full capacity tables at 0.01 - $\mathrm{ft}$ increments of elevation, and associated metadata are available in Nystrom and others (2021).

\section{Accuracy Assessment}

The accuracy of the mapped bathymetric data was evaluated using quality assurance datasets collected with a singlebeam echosounder, as described in the "Quality Assurance Dataset: Single-beam Echosounder" section of this report, similar to methods described by Wilson and Richards (2006). About 284,000 quality assurance point observations were spatially joined with the mapped raster surfaces in a GIS, the measured elevations were compared (figs. $10 D$ and $E$ to $25 D$ and $E$, in back of report), descriptive statistics were calculated. Two additional datasets were used for quality assurance of the bathymetric data in a part of the mapped area: a series of GNSS survey points recorded in Boyd Corners Reservoir and lidar data points along the shorelines of Bog Brook and East
Branch Reservoirs. Both additional quality assurance datasets were recorded during periods of unusually low water levels. These two additional datasets allowed a quality assurance assessment with data sources that were more independent than the single-beam echosounder dataset because they did not require two of the processing steps used for the mapping data: the use of corrections for sound velocity over depth and the use of the water surface elevation as a reference to NAVD 88 . In addition, the lidar dataset allowed a quality assurance assessment of the ADCP and single-beam echosounder datasets.

The National Standard for Spatial Data Accuracy (Federal Geographic Data Committee, 1998) defines a standard for assessing map accuracy based on the root mean square error (RMSE) of the data. Assuming the errors are normally distributed, the vertical accuracy of the map product can be calculated at the 95-percent accuracy level as 1.96 times the RMSE. Because it is not possible to separate the effects of many different factors on each measured point in the dataset, this accuracy assessment includes the cumulative effects of many potential sources of errors or inaccuracies in the multibeam and reference quality assurance datasets; these can include inaccuracies in the measurements of depth, position, attitude of the boat (pitch, roll, heading, and heave), sound velocity, time synchronization errors, and other sources of measurement error. 
Table 14. Reservoir area and capacity at specified elevations for New York City's East of Hudson reservoirs and controlled lakes, in Westchester and Putnam Counties, New York.

[Locations of reservoirs shown on figure 1. Expanded elevation-area-capacity for the reservoirs and controlled lakes are available in Nystrom and others (2021). NAVD 88, North American Vertical Datum of 1988]

\begin{tabular}{ccccc}
\hline $\begin{array}{c}\text { Elevation, } \\
\text { in feet } \\
\text { above } \\
\text { NAVD 88 }\end{array}$ & $\begin{array}{c}\text { Depth } \\
\text { below } \\
\text { spillway, } \\
\text { in feet }\end{array}$ & $\begin{array}{c}\text { Capacity, } \\
\text { in million } \\
\text { gallons }\end{array}$ & $\begin{array}{c}\text { Area, } \\
\text { in square } \\
\text { miles }\end{array}$ & $\begin{array}{c}\text { Area, } \\
\text { in acres }\end{array}$ \\
\hline
\end{tabular}

\begin{tabular}{lrcll}
\hline \multicolumn{5}{c}{ Amawalk Reservoir } \\
\hline 402.32 & -4 & 7,509 & 0.9536 & 610.3 \\
398.32 & 0 & 6,731 & 0.9085 & 581.4 \\
388.32 & 10 & 4,968 & 0.7719 & 494 \\
378.32 & 20 & 3,509 & 0.6359 & 407 \\
368.32 & 30 & 2,329 & 0.4915 & 314.6 \\
358.32 & 40 & 1,419 & 0.3919 & 250.8 \\
348.32 & 50 & 689.9 & 0.3027 & 193.8 \\
338.32 & 60 & 183.3 & 0.173 & 110.7 \\
328.32 & 70 & 0.3604 & 0.002664 & 1.705 \\
\hline
\end{tabular}

\begin{tabular}{|c|c|c|c|c|}
\hline \multicolumn{5}{|c|}{ Bog Brook Reservoir } \\
\hline 419.54 & -4 & 5,004 & 0.6471 & 414.2 \\
\hline 415.54 & 0 & 4,473 & 0.6284 & 402.2 \\
\hline 405.54 & 10 & 3,230 & 0.5638 & 360.8 \\
\hline 395.54 & 20 & 2,126 & 0.4945 & 316.5 \\
\hline 385.54 & 30 & 1,168 & 0.4215 & 269.8 \\
\hline 375.54 & 40 & 392.9 & 0.3075 & 196.8 \\
\hline 365.54 & 50 & 66.06 & 0.0358 & 22.91 \\
\hline 355.54 & 60 & 10.17 & 0.01931 & 12.36 \\
\hline \multicolumn{5}{|c|}{ Boyd Corners } \\
\hline 583.29 & -4 & 2,003 & 0.3758 & 240.5 \\
\hline 579.29 & 0 & 1,700 & 0.3469 & 222 \\
\hline 569.29 & 10 & 1,045 & 0.281 & 179.8 \\
\hline 559.29 & 20 & 529.3 & 0.2087 & 133.5 \\
\hline 549.29 & 30 & 170.5 & 0.1346 & 86.14 \\
\hline 539.29 & 40 & 6.826 & 0.02792 & 17.87 \\
\hline \multicolumn{5}{|c|}{ Cross River Reservoir } \\
\hline 332.23 & -4 & 11,580 & 1.508 & 965.1 \\
\hline 328.23 & 0 & 10,350 & 1.431 & 915.6 \\
\hline 318.23 & 10 & 7,553 & 1.238 & 792.4 \\
\hline 308.23 & 20 & 5,212 & 1.012 & 647.4 \\
\hline 298.23 & 30 & 3,327 & 0.7829 & 501 \\
\hline 288.23 & 40 & 1,934 & 0.5581 & 357.2 \\
\hline 278.23 & 50 & 1,040 & 0.3064 & 196.1 \\
\hline 268.23 & 60 & 602.2 & 0.134 & 85.77 \\
\hline 258.23 & 70 & 384.1 & 0.08973 & 57.43 \\
\hline 248.23 & 80 & 217.1 & 0.07027 & 44.97 \\
\hline
\end{tabular}

Table 14. Reservoir area and capacity at specified elevations for New York City's East of Hudson reservoirs and controlled lakes, in Westchester and Putnam Counties, New York.-Continued

[Locations of reservoirs shown on figure 1. Expanded elevation-area-capacity for the reservoirs and controlled lakes are available in Nystrom and others (2021). NAVD 88, North American Vertical Datum of 1988]

\begin{tabular}{|c|c|c|c|c|}
\hline $\begin{array}{l}\text { Elevation, } \\
\text { in feet } \\
\text { above } \\
\text { NAVD } 88\end{array}$ & $\begin{array}{c}\text { Depth } \\
\text { below } \\
\text { spillway, } \\
\text { in feet }\end{array}$ & $\begin{array}{c}\text { Capacity, } \\
\text { in million } \\
\text { gallons }\end{array}$ & $\begin{array}{c}\text { Area, } \\
\text { in square } \\
\text { miles }\end{array}$ & $\begin{array}{c}\text { Area, } \\
\text { in acres }\end{array}$ \\
\hline \multicolumn{5}{|c|}{ Cross River Reservoir-Continued } \\
\hline 238.23 & 90 & 95.08 & 0.04613 & 29.52 \\
\hline 228.23 & 100 & 21.94 & 0.02402 & 15.37 \\
\hline 218.23 & 110 & 0.6483 & 0.001887 & 1.208 \\
\hline \multicolumn{5}{|c|}{ Croton Falls Reservoir } \\
\hline 311.83 & -4 & 15,400 & 1.778 & 1,138 \\
\hline 307.83 & 0 & 13,950 & 1.693 & 1,084 \\
\hline 297.83 & 10 & 10,690 & 1.44 & 921.6 \\
\hline 287.83 & 20 & 7,973 & 1.151 & 736.7 \\
\hline 277.83 & 30 & 5,883 & 0.8728 & 558.6 \\
\hline 267.83 & 40 & 4,240 & 0.7052 & 451.3 \\
\hline 257.83 & 50 & 2,906 & 0.5748 & 367.9 \\
\hline 247.83 & 60 & 1,827 & 0.4698 & 300.7 \\
\hline 237.83 & 70 & 959 & 0.3534 & 226.1 \\
\hline 227.83 & 80 & 361.3 & 0.2219 & 142 \\
\hline 217.83 & 90 & 49.7 & 0.07916 & 50.66 \\
\hline 207.83 & 100 & 0.3922 & 0.000972 & 0.6219 \\
\hline \multicolumn{5}{|c|}{ Diverting Reservoir } \\
\hline 312.11 & -4 & 1,019 & 0.258 & 165.1 \\
\hline 308.11 & 0 & 814.3 & 0.2358 & 150.9 \\
\hline 298.11 & 10 & 392 & 0.1679 & 107.5 \\
\hline 288.11 & 20 & 113.8 & 0.09867 & 63.15 \\
\hline 278.11 & 30 & 2.518 & 0.01056 & 6.759 \\
\hline \multicolumn{5}{|c|}{ East Branch Reservoir } \\
\hline 419.54 & -4 & 6,005 & 1.26 & 806.2 \\
\hline 415.54 & 0 & 5,123 & 0.9024 & 577.5 \\
\hline 405.54 & 10 & 3,459 & 0.7142 & 457.1 \\
\hline 395.54 & 20 & 2,172 & 0.4976 & 318.5 \\
\hline 385.54 & 30 & 1,263 & 0.3774 & 241.5 \\
\hline 375.54 & 40 & 602 & 0.255 & 163.2 \\
\hline 365.54 & 50 & 188.6 & 0.1506 & 96.39 \\
\hline 355.54 & 60 & 6.562 & 0.022 & 14.08 \\
\hline \multicolumn{5}{|c|}{ Lake Gilead } \\
\hline 496.6 & -4 & 2,013 & 0.1932 & 123.7 \\
\hline 492.6 & 0 & 1,859 & 0.1754 & 112.3 \\
\hline 482.6 & 10 & 1,513 & 0.1555 & 99.51 \\
\hline 472.6 & 20 & 1,213 & 0.1355 & 86.73 \\
\hline
\end{tabular}


Table 14. Reservoir area and capacity at specified elevations for New York City's East of Hudson reservoirs and controlled lakes, in Westchester and Putnam Counties, New York.-Continued

[Locations of reservoirs shown on figure 1. Expanded elevation-area-capacity for the reservoirs and controlled lakes are available in Nystrom and others (2021). NAVD 88, North American Vertical Datum of 1988]

\begin{tabular}{ccccc}
\hline $\begin{array}{c}\text { Elevation, } \\
\text { in feet } \\
\text { above } \\
\text { NAVD } 88\end{array}$ & $\begin{array}{c}\text { Depth } \\
\text { below } \\
\text { spillway, } \\
\text { in feet }\end{array}$ & $\begin{array}{c}\text { Capacity, } \\
\text { in million } \\
\text { gallons }\end{array}$ & $\begin{array}{c}\text { Area, } \\
\text { in square } \\
\text { miles }\end{array}$ & $\begin{array}{c}\text { Area, } \\
\text { in acres }\end{array}$ \\
\hline
\end{tabular}

\begin{tabular}{lrcll}
\hline \multicolumn{5}{c}{ Lake Gilead-Continued } \\
\hline 462.6 & 30 & 948.8 & 0.1137 & 72.78 \\
452.6 & 40 & 730.5 & 0.09681 & 61.96 \\
442.6 & 50 & 542 & 0.08463 & 54.17 \\
432.6 & 60 & 377.8 & 0.07238 & 46.32 \\
422.6 & 70 & 240.9 & 0.05863 & 37.52 \\
412.6 & 80 & 134.3 & 0.0435 & 27.84 \\
402.6 & 90 & 59.33 & 0.02915 & 18.66 \\
392.6 & 100 & 12.92 & 0.0132 & 8.448 \\
382.6 & 110 & 0.612 & 0.001606 & 1.028 \\
\hline
\end{tabular}

\begin{tabular}{lrlll}
\hline \multicolumn{5}{c}{ Lake Gleneida } \\
\hline 505 & -4 & 2,938 & 0.2787 & 178.4 \\
501 & 0 & 2,709 & 0.268 & 171.5
\end{tabular}

\begin{tabular}{lccll}
491 & 10 & 2,176 & 0.2414 & 154.5 \\
481 & 20 & 1,703 & 0.2164 & 138.5 \\
471 & 30 & 1,275 & 0.1946 & 124.6 \\
461 & 40 & 898.6 & 0.1625 & 104 \\
451 & 50 & 594.4 & 0.1326 & 84.85 \\
441 & 60 & 342.2 & 0.1082 & 69.27 \\
431 & 70 & 160.6 & 0.0634 & 40.58 \\
421 & 80 & 60.17 & 0.03441 & 22.02 \\
411 & 90 & 13.68 & 0.01195 & 7.648 \\
401 & 100 & 0.02733 & 0.000588 & 0.3764 \\
\hline
\end{tabular}

\begin{tabular}{|c|c|c|c|c|}
\hline \multicolumn{5}{|c|}{ Kensico Reservoir } \\
\hline 359.98 & -4 & 44,160 & 3.636 & 2,327 \\
\hline 355.98 & 0 & 41,200 & 3.466 & 2,218 \\
\hline 345.98 & 10 & 34,330 & 3.109 & 1,989 \\
\hline 335.98 & 20 & 28,260 & 2.707 & 1,733 \\
\hline 325.98 & 30 & 23,070 & 2.288 & 1,465 \\
\hline 315.98 & 40 & 18,600 & 2.004 & 1,283 \\
\hline 305.98 & 50 & 14,730 & 1.715 & 1,098 \\
\hline 295.98 & 60 & 11,410 & 1.47 & 940.9 \\
\hline 285.98 & 70 & 8,663 & 1.142 & 730.6 \\
\hline 275.98 & 80 & 6,554 & 0.9366 & 599.4 \\
\hline 265.98 & 90 & 4,727 & 0.8041 & 514.7 \\
\hline 255.98 & 100 & 3,175 & 0.6841 & 437.8 \\
\hline 245.98 & 110 & 1,915 & 0.4857 & 310.8 \\
\hline
\end{tabular}

Table 14. Reservoir area and capacity at specified elevations for New York City's East of Hudson reservoirs and controlled lakes, in Westchester and Putnam Counties, New York.-Continued

[Locations of reservoirs shown on figure 1. Expanded elevation-area-capacity for the reservoirs and controlled lakes are available in Nystrom and others (2021). NAVD 88, North American Vertical Datum of 1988]

\begin{tabular}{|c|c|c|c|c|}
\hline $\begin{array}{l}\text { Elevation, } \\
\text { in feet } \\
\text { above } \\
\text { NAVD } 88\end{array}$ & $\begin{array}{l}\text { Depth } \\
\text { below } \\
\text { spillway, } \\
\text { in feet }\end{array}$ & $\begin{array}{c}\text { Capacity, } \\
\text { in million } \\
\text { gallons }\end{array}$ & $\begin{array}{c}\text { Area, } \\
\text { in square } \\
\text { miles }\end{array}$ & $\begin{array}{c}\text { Area, } \\
\text { in acres }\end{array}$ \\
\hline \multicolumn{5}{|c|}{ Kensico Reservoir-Continued } \\
\hline 235.98 & 120 & 1,115 & 0.3169 & 202.8 \\
\hline 225.98 & 130 & 550.4 & 0.2214 & 141.7 \\
\hline 215.98 & 140 & 179 & 0.1316 & 84.25 \\
\hline 205.98 & 150 & 17.08 & 0.03009 & 19.26 \\
\hline 195.98 & 160 & 0.01211 & 0.00015 & 0.096 \\
\hline \multicolumn{5}{|c|}{ Kirk Lake } \\
\hline 589.63 & -4 & 817.4 & 0.3654 & 233.9 \\
\hline 585.63 & 0 & 574 & 0.2051 & 131.3 \\
\hline 575.63 & 10 & 228.6 & 0.1324 & 84.74 \\
\hline 565.63 & 20 & 16.88 & 0.04861 & 31.11 \\
\hline \multicolumn{5}{|c|}{ Middle Branch Reservoir } \\
\hline 372.7 & -4 & 4,428 & 0.6958 & 445.3 \\
\hline 368.7 & 0 & 3,862 & 0.6585 & 421.4 \\
\hline 358.7 & 10 & 2,589 & 0.5599 & 358.3 \\
\hline 348.7 & 20 & 1,530 & 0.4578 & 293 \\
\hline 338.7 & 30 & 688.4 & 0.3387 & 216.7 \\
\hline 328.7 & 40 & 146.2 & 0.1678 & 107.4 \\
\hline 318.7 & 50 & 1.215 & 0.002277 & 1.457 \\
\hline \multicolumn{5}{|c|}{ Muscoot Reservoir } \\
\hline 202.02 & -4 & 4,722 & 1.487 & 951.6 \\
\hline 198.02 & 0 & 3,573 & 1.248 & 798.7 \\
\hline 188.02 & 10 & 1,496 & 0.7984 & 511 \\
\hline 178.02 & 20 & 267.6 & 0.3294 & 210.8 \\
\hline 168.02 & 30 & 5.821 & 0.02121 & 13.58 \\
\hline \multicolumn{5}{|c|}{ New Croton Reservoir } \\
\hline 198.25 & -4 & 31,770 & 3.466 & 2,218 \\
\hline 194.25 & 0 & 28,950 & 3.282 & 2,100 \\
\hline 184.25 & 10 & 22,560 & 2.851 & 1,825 \\
\hline 174.25 & 20 & 17,090 & 2.384 & 1,526 \\
\hline 164.25 & 30 & 12,600 & 1.884 & 1,206 \\
\hline 154.25 & 40 & 9,367 & 1.244 & 796.2 \\
\hline 144.25 & 50 & 7,120 & 0.9481 & 606.8 \\
\hline 134.25 & 60 & 5,354 & 0.7669 & 490.8 \\
\hline 124.25 & 70 & 3,902 & 0.6282 & 402.1 \\
\hline 114.25 & 80 & 2,739 & 0.4934 & 315.7 \\
\hline 104.25 & 90 & 1,813 & 0.3865 & 247.4 \\
\hline
\end{tabular}


Table 14. Reservoir area and capacity at specified elevations for New York City's East of Hudson reservoirs and controlled lakes, in Westchester and Putnam Counties, New York.-Continued

[Locations of reservoirs shown on figure 1. Expanded elevation-area-capacity for the reservoirs and controlled lakes are available in Nystrom and others (2021). NAVD 88, North American Vertical Datum of 1988]

\begin{tabular}{|c|c|c|c|c|}
\hline $\begin{array}{l}\text { Elevation, } \\
\text { in feet } \\
\text { above } \\
\text { NAVD } 88\end{array}$ & $\begin{array}{c}\text { Depth } \\
\text { below } \\
\text { spillway, } \\
\text { in feet }\end{array}$ & $\begin{array}{c}\text { Capacity, } \\
\text { in million } \\
\text { gallons }\end{array}$ & $\begin{array}{c}\text { Area, } \\
\text { in square } \\
\text { miles }\end{array}$ & $\begin{array}{c}\text { Area, } \\
\text { in acres }\end{array}$ \\
\hline \multicolumn{5}{|c|}{ New Croton Reservoir-Continued } \\
\hline 94.25 & 100 & 1,105 & 0.3 & 192 \\
\hline 84.25 & 110 & 555.5 & 0.2218 & 142 \\
\hline 74.25 & 120 & 202.3 & 0.1059 & 67.75 \\
\hline 64.25 & 130 & 63 & 0.03995 & 25.57 \\
\hline 54.25 & 140 & 8.155 & 0.01391 & 8.9 \\
\hline \multicolumn{5}{|c|}{ Titicus Reservoir } \\
\hline 327.23 & -4 & 7,970 & 1.116 & 714 \\
\hline 323.23 & 0 & 7,067 & 1.046 & 669.3 \\
\hline 313.23 & 10 & 5,055 & 0.876 & 560.6 \\
\hline 303.23 & 20 & 3,409 & 0.7002 & 448.1 \\
\hline 293.23 & 30 & 2,122 & 0.5371 & 343.7 \\
\hline 283.23 & 40 & 1,186 & 0.3664 & 234.5 \\
\hline 273.23 & 50 & 549.6 & 0.2357 & 150.8 \\
\hline 263.23 & 60 & 191.4 & 0.1216 & 77.85 \\
\hline 253.23 & 70 & 26.15 & 0.03079 & 19.71 \\
\hline 243.23 & 80 & 1.145 & 0.002669 & 1.708 \\
\hline \multicolumn{5}{|c|}{ West Branch Reservoir } \\
\hline 505.92 & -4 & 11,430 & 1.765 & 1,129 \\
\hline 501.92 & 0 & 9,987 & 1.686 & 1,079 \\
\hline 491.92 & 10 & 6,659 & 1.503 & 961.7 \\
\hline 481.92 & 20 & 3,762 & 1.262 & 807.9 \\
\hline 471.92 & 30 & 1,534 & 0.7894 & 505.2 \\
\hline 461.92 & 40 & 334.8 & 0.3785 & 242.3 \\
\hline 451.92 & 50 & 0.4866 & 0.003615 & 2.314 \\
\hline
\end{tabular}

\section{Single-Beam Echosounder Dataset}

Elevation measurement errors were calculated by subtracting the mapped raster surface elevation from the measured single-beam echosounder point elevation whenever a single-beam echosounder point fell within a mapped $3.28-\mathrm{ft}$ grid cell; descriptive statistics were then calculated for each reservoir (tables 15 and 16). The mean error for all mapped quality assurance points in the $\mathrm{EOH}$ reservoirs and controlled lakes was $0.35 \mathrm{ft}$ and ranged from $0.12 \mathrm{ft}$ at Middle Branch and Muscoot Reservoirs to $0.63 \mathrm{ft}$ at Kensico Reservoir. The 95-percent accuracy (computed from the RMSE of the errors) for all mapped single-beam echosounder quality assurance points in the EOH reservoirs and controlled lakes was $1.68 \mathrm{ft}$ and ranged from $0.58 \mathrm{ft}$ at Bog Brook Reservoir to $2.92 \mathrm{ft}$ at New Croton Reservoir. The elevations measured with the single-beam echosounder averaged slightly above (shallower than) the elevation measured with the multibeam echosounder (positive errors; figs. $10 D$ to $25 D$, in back of report). Sloped areas of a reservoir bottom can cause a shallow bias in singlebeam echosounder measurements compared with multibeam echosounder measurements because of the acoustic beam width and the typical incidence angle of the acoustic beams; this effect is illustrated in Nystrom and Collenburg (2020).

The quality assurance points were categorized by the grid cell data source, and accuracy statistics were recomputed by category. The 95-percent accuracy of the areas measured with the multibeam echosounder was $1.67 \mathrm{ft}$ (table 15); the accuracy in the areas where the data were interpolated was $2.74 \mathrm{ft}$, and the accuracy in the areas where the data were derived from lidar was $0.56 \mathrm{ft}$. The accuracy statistics were also categorized by the slope of the mapped surface (table 16); in very flat areas (slope less than $1^{\circ}$ ), the overall 95-percent accuracy was $0.55 \mathrm{ft}$ compared with $6.63 \mathrm{ft}$ in areas with slopes of $30^{\circ}$ to $40^{\circ}$. In addition, the steeper the slope of the mapped surface, the larger the mean error, with the single-beam echosounder quality assurance points plotting shallower on average (table 16, positive mean errors). Mapping in steep areas may easily result in large errors because even small errors in time synchronization or measurement of boat position and attitude or in the position of the measured point within the mapped cell can result in large errors in measured depth. In addition, the single-beam echosounder has a wider acoustic beam than the multibeam echosounder, and the geometry of the beams and how they are reflected from the reservoir bottom can cause the single-beam echosounder to measure a shallower depth than the multibeam echosounder (Nystrom and Collenburg, 2020).

Because the capacity, or volume, of a reservoir represents a spatial average of the depth measurements, the accuracy of the computed capacity can be assessed by calculating confidence intervals around the mean error of the quality assurance points compared to the grids. This accuracy assessment of the capacity is calculated using the sample mean error and variance, as adapted from Helsel and others (2020) and as shown in Nystrom (2018). For the EOH reservoirs and controlled lakes, the confidence interval of the computed capacity at spillway elevation at 95 -percent accuracy level was \pm 1.6 percent or less (table 17). 
Table 15. Accuracy assessment of elevations of single-beam echosounder quality assurance points compared with mapped raster surfaces for bathymetric surveys of New York City's East of Hudson reservoirs and controlled lakes, in Westchester and Putnam Counties, New York.

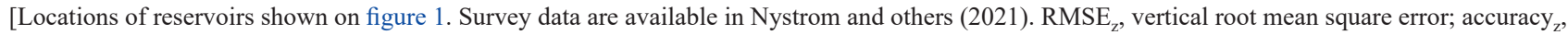
National Standard for Spatial Data Accuracy fundamental vertical accuracy calculated at the 95-percent confidence level; lidar, light detection and ranging]

\begin{tabular}{|c|c|c|c|c|c|}
\hline Grid cell data source & Number of points & $\begin{array}{c}\text { Mean error, } \\
\text { in feet }\end{array}$ & $\begin{array}{l}\text { Median error, } \\
\text { in feet }\end{array}$ & $\begin{array}{l}\text { RMSE }_{z^{\prime}} \\
\text { in feet }\end{array}$ & $\begin{array}{l}\text { Accuracy }_{z^{\prime}} \\
\text { in feet }\end{array}$ \\
\hline \multicolumn{6}{|c|}{ Amawalk Reservoir } \\
\hline Overall & 15,271 & 0.45 & 0.36 & 1.02 & 2.00 \\
\hline Multibeam echosounder & 15,133 & 0.45 & 0.36 & 1.01 & 1.98 \\
\hline Interpolated & 138 & 0.47 & 0.17 & 1.71 & 3.35 \\
\hline \multicolumn{6}{|c|}{ Bog Brook Reservoir } \\
\hline Overall & 18,711 & 0.15 & 0.12 & 0.30 & 0.58 \\
\hline Multibeam echosounder & 18,324 & 0.15 & 0.12 & 0.30 & 0.58 \\
\hline Lidar & 288 & -0.06 & -0.08 & 0.25 & 0.49 \\
\hline Interpolated & 99 & 0.00 & -0.06 & 0.46 & 0.90 \\
\hline \multicolumn{6}{|c|}{ Boyd Corners Reservoir } \\
\hline Overall & 10,049 & 0.25 & 0.22 & 0.38 & 0.74 \\
\hline Multibeam echosounder & 9,972 & 0.25 & 0.21 & 0.38 & 0.74 \\
\hline Interpolated & 77 & 0.41 & 0.49 & 0.55 & 1.07 \\
\hline \multicolumn{6}{|c|}{ Cross River Reservoir } \\
\hline Overall & 20,336 & 0.24 & 0.14 & 0.56 & 1.11 \\
\hline Multibeam echosounder & 20,261 & 0.24 & 0.14 & 0.56 & 1.11 \\
\hline Interpolated & 75 & 0.24 & 0.23 & 0.71 & 1.40 \\
\hline \multicolumn{6}{|c|}{ Croton Falls Reservoir } \\
\hline Overall & 27,847 & 0.53 & 0.22 & 1.25 & 2.44 \\
\hline Multibeam echosounder & 27,539 & 0.53 & 0.22 & 1.25 & 2.44 \\
\hline Lidar & 127 & -0.02 & -0.07 & 0.22 & 0.43 \\
\hline Interpolated & 181 & 0.78 & 0.17 & 1.72 & 3.37 \\
\hline \multicolumn{6}{|c|}{ Diverting Reservoir } \\
\hline Overall & 8,845 & 0.18 & 0.17 & 0.47 & 0.93 \\
\hline Multibeam echosounder & 8,589 & 0.19 & 0.17 & 0.47 & 0.92 \\
\hline Lidar & 195 & -0.10 & -0.06 & 0.37 & 0.72 \\
\hline Int & 61 & 0.58 & 0.57 & 1.05 & 2.06 \\
\hline \multicolumn{6}{|c|}{ East Branch Reservoir } \\
\hline Overall & 20,142 & 0.37 & 0.23 & 0.69 & 1.36 \\
\hline Multibeam echosounder & 20,104 & 0.37 & 0.23 & 0.69 & 1.36 \\
\hline Interpolated & 38 & 0.94 & 0.79 & 1.30 & 2.54 \\
\hline \multicolumn{6}{|c|}{ Lake Gilead } \\
\hline Overall & 5,945 & 0.32 & 0.24 & 1.23 & 2.41 \\
\hline Multibeam echosounder & 5,823 & 0.32 & 0.24 & 1.23 & 2.41 \\
\hline Interpolated & 122 & 0.03 & 0.11 & 1.22 & 2.39 \\
\hline \multicolumn{6}{|c|}{ Lake Gleneida } \\
\hline Overall & 14,960 & 0.51 & 0.42 & 0.74 & 1.45 \\
\hline Multibeam echosounder & 14,900 & 0.51 & 0.42 & 0.72 & 1.41 \\
\hline Interpolated & 60 & 2.12 & 1.44 & 3.03 & 5.94 \\
\hline
\end{tabular}


Table 15. Accuracy assessment of elevations of single-beam echosounder quality assurance points compared with mapped raster surfaces for bathymetric surveys of New York City's East of Hudson reservoirs and controlled lakes, in Westchester and Putnam Counties, New York.-Continued

[Locations of reservoirs shown on figure 1. Survey data are available in Nystrom and others (2021). $\mathrm{RMSE}_{\mathrm{z}}$, vertical root mean square error; accuracy ${ }_{z}$, National Standard for Spatial Data Accuracy fundamental vertical accuracy calculated at the 95-percent confidence level; lidar, light detection and ranging]

\begin{tabular}{|c|c|c|c|c|c|}
\hline Grid cell data source & Number of points & $\begin{array}{l}\text { Mean error, } \\
\text { in feet }\end{array}$ & $\begin{array}{l}\text { Median error, } \\
\text { in feet }\end{array}$ & $\begin{array}{l}\text { RMSE }_{z^{\prime}} \\
\text { in feet }\end{array}$ & $\begin{array}{l}\text { Accuracy }_{z^{\prime}} \\
\text { in feet }\end{array}$ \\
\hline \multicolumn{6}{|c|}{ Kensico Reservoir } \\
\hline Overall & 27,315 & 0.63 & 0.37 & 1.20 & 2.35 \\
\hline Multibeam echosounder & 27,213 & 0.63 & 0.37 & 1.19 & 2.34 \\
\hline Interpolated & 102 & 0.78 & 0.24 & 1.82 & 3.56 \\
\hline \multicolumn{6}{|c|}{ Kirk Lake } \\
\hline Overall & 15,345 & 0.17 & 0.11 & 0.43 & 0.84 \\
\hline Multibeam echosounder & 15,227 & 0.16 & 0.11 & 0.42 & 0.83 \\
\hline Interpolated & 118 & 0.62 & 0.56 & 0.95 & 1.86 \\
\hline \multicolumn{6}{|c|}{ Middle Branch Reservoir } \\
\hline Overall & 12,020 & 0.12 & 0.11 & 0.34 & 0.67 \\
\hline Multibeam echosounder & 11,977 & 0.12 & 0.11 & 0.34 & 0.66 \\
\hline Interpolated & 43 & 0.42 & 0.15 & 0.92 & 1.80 \\
\hline \multicolumn{6}{|c|}{ Muscoot Reservoir } \\
\hline Overall & 16,808 & 0.12 & 0.14 & 0.35 & 0.68 \\
\hline Multibeam echosounder & 16,667 & 0.12 & 0.14 & 0.34 & 0.67 \\
\hline Interpolated & 141 & 0.32 & 0.24 & 0.81 & 1.58 \\
\hline \multicolumn{6}{|c|}{ New Croton Reservoir } \\
\hline Overall & 18,568 & 0.46 & 0.15 & 1.49 & 2.92 \\
\hline Multibeam echosounder & 18,446 & 0.46 & 0.15 & 1.48 & 2.91 \\
\hline Interpolated & 122 & 0.94 & 0.50 & 2.23 & 4.37 \\
\hline \multicolumn{6}{|c|}{ Titicus Reservoir } \\
\hline Overall & 17,669 & 0.52 & 0.37 & 0.95 & 1.86 \\
\hline Multibeam echosounder & 17,563 & 0.52 & 0.37 & 0.95 & 1.86 \\
\hline Interpolated & 106 & 0.61 & 0.59 & 1.18 & 2.30 \\
\hline \multicolumn{6}{|c|}{ West Branch Reservoir } \\
\hline Overall & 33,916 & 0.25 & 0.22 & 0.47 & 0.92 \\
\hline Multibeam echosounder & 33,717 & 0.25 & 0.22 & 0.47 & 0.92 \\
\hline Interpolated & 199 & 0.30 & 0.20 & 0.64 & 1.25 \\
\hline \multicolumn{6}{|c|}{ All East of Hudson reservoirs and controlled lakes } \\
\hline Overall & 283,747 & 0.35 & 0.21 & 0.86 & 1.68 \\
\hline Multibeam echosounder & 281,455 & 0.35 & 0.21 & 0.85 & 1.67 \\
\hline Lidar & 610 & -0.06 & -0.07 & 0.29 & 0.56 \\
\hline Interpolated & 1,682 & 0.54 & 0.30 & 1.40 & 2.74 \\
\hline
\end{tabular}


Table 16. Accuracy assessment of elevations of single-beam echosounder quality assurance points compared with mapped raster surfaces, categorized by slope, for bathymetric surveys of New York City's East of Hudson reservoirs and controlled lakes, in Westchester and Putnam Counties, New York.

[Locations of reservoirs shown on figure 1. Survey data are available in Nystrom and others (2021). RMSE ${ }_{z}$, vertical root mean square error; accuracy National Standard for Spatial Data Accuracy fundamental vertical accuracy calculated at the 95-percent confidence level]

\begin{tabular}{cccccc}
\hline $\begin{array}{c}\text { Slope, } \\
\text { in degrees }\end{array}$ & Number of points & $\begin{array}{c}\text { Mean error, } \\
\text { in feet }\end{array}$ & $\begin{array}{c}\text { Median error, } \\
\text { in feet }\end{array}$ & $\begin{array}{c}\text { RMSE }_{\mathbf{z}^{\prime}} \\
\text { in feet }\end{array}$ & $\begin{array}{c}\text { Accuracy }_{\mathbf{z}^{\prime}} \\
\text { in feet }\end{array}$ \\
\hline 0 to 1 & 85,401 & 0.17 & 0.15 & 0.28 & 0.55 \\
$>1$ to 10 & 154,846 & 0.28 & 0.21 & 0.59 & 1.16 \\
$>10$ to 20 & 32,724 & 0.73 & 0.49 & 1.41 & 2.77 \\
$>20$ to 30 & 8,412 & 1.58 & 1.22 & 2.51 & 4.92 \\
$>30$ to 40 & 2,254 & 2.39 & 1.97 & 3.38 & 6.63 \\
$>40$ to 50 & 94 & 2.63 & 2.74 & 4.17 & 8.18 \\
$>50$ to 60 & 15 & 5.53 & 3.9 & 7.85 & 15.39 \\
\hline
\end{tabular}

Table 17. Accuracy assessment of computed capacity at spillway elevation for bathymetric surveys of New York City's East of Hudson reservoirs and controlled lakes, in Westchester and Putnam Counties, New York.

[Locations of reservoirs shown on figure 1. Survey data are available in Nystrom and others (2021). Mean error and variance computed by comparing single beam echosounder point elevations to mapped raster surfaces. Confidence intervals calculated at 95-percent level]

\begin{tabular}{lccccc}
\hline \multicolumn{1}{c}{ Reservoir } & $\begin{array}{c}\text { Mean error, } \\
\text { in feet }\end{array}$ & $\begin{array}{c}\text { Variance, } \\
\text { in feet }^{2}\end{array}$ & $\begin{array}{c}\text { Confidence interval } \\
\text { of mean elevation, }_{\text {in feet }}\end{array}$ & $\begin{array}{c}\text { Confidence interval of capac- } \\
\text { ity at spillway elevation, } \\
\text { in millions of gallons }\end{array}$ & $\begin{array}{c}\text { Confidence interval of capac- } \\
\text { ity at spillway elevation, } \\
\text { in percent }\end{array}$ \\
\hline Amawalk Reservoir & 0.45 & 0.84 & \pm 0.46 & \pm 87.7 & \pm 1.3 \\
Bog Brook Reservoir & 0.15 & 0.07 & \pm 0.15 & \pm 19.9 & \pm 0.4 \\
Boyd Corners Reservoir & 0.25 & 0.08 & \pm 0.26 & \pm 18.7 & \pm 1.1 \\
Cross River Reservoir & 0.24 & 0.26 & \pm 0.25 & \pm 74.3 & \pm 0.7 \\
Croton Falls Reservoir & 0.53 & 1.28 & \pm 0.54 & \pm 190.4 & \pm 1.4 \\
Diverting Reservoir & 0.18 & 0.19 & \pm 0.19 & \pm 9.5 & \pm 1.2 \\
East Branch Reservoir & 0.37 & 0.35 & \pm 0.38 & \pm 70.9 & \pm 1.4 \\
Lake Gilead & 0.32 & 1.41 & \pm 0.35 & \pm 12.7 & \pm 0.7 \\
Lake Gleneida & 0.51 & 0.29 & \pm 0.52 & \pm 29.2 & \pm 1.1 \\
Kensico Reservoir & 0.63 & 1.04 & \pm 0.64 & \pm 463.8 & \pm 1.1 \\
Kirk Lake & 0.17 & 0.16 & \pm 0.17 & \pm 7.5 & \pm 1.3 \\
Middle Branch Reservoir & 0.12 & 0.10 & \pm 0.12 & \pm 16.9 & \pm 0.4 \\
Muscoot Reservoir & 0.12 & 0.11 & \pm 0.13 & \pm 33.1 & \pm 0.9 \\
New Croton Reservoir & 0.46 & 2.01 & \pm 0.48 & \pm 328.9 & \pm 1.1 \\
Titicus Reservoir & 0.52 & 0.63 & \pm 0.53 & \pm 116.2 & \pm 1.6 \\
West Branch Reservoir & 0.25 & 0.16 & \pm 0.26 & \pm 90.1 & \pm 0.9 \\
\hline
\end{tabular}




\section{GNSS and Lidar Datasets}

A set of GNSS survey points was recorded by the NYCDEP at Boyd Corners Reservoir during a period of low water levels in 2020. GNSS points were collected using NYSNet VRS RTK corrections on the reservoir bottom as much as $35 \mathrm{ft}$ below the spillway elevation; 185 points were recorded that overlapped with the bathymetric surface mapped for this study, including 139 points that overlapped with the multibeam data (table 18). The mean error of the GNSS points compared with the mean error in areas measured with the multibeam echosounder was $-0.02 \mathrm{ft}$, and the 95 percent accuracy was $0.86 \mathrm{ft}$.

The lidar data used in this study (NYCDEP, 2009) were collected during a period of low water levels (about $30 \mathrm{ft}$ below the spillway elevation) at Bog Brook and East Branch Reservoirs. Although this overlap of lidar data and the surveyed areas was limited to a shallow portion of these two reservoirs, and therefore does not represent the full range of survey conditions in the $\mathrm{EOH}$ reservoirs and controlled lakes, it allowed for a quality assurance assessment of the singlebeam echosounder data and the ADCP data. Individual lidar data points from the LAS files were spatially joined to mapped raster surfaces and to single-beam echosounder points within a 1-ft radius of a lidar data point. Because individual lidar data points were used, the user should be aware that some variability is inherent in these single point measurements; the metadata for the lidar dataset specifies that the RMSE of the lidar points compared with ground control checkpoints was less than $0.61 \mathrm{ft}$ (NYCDEP, 2009).

The 95 percent accuracy computed by comparing the elevations of the lidar data points with those in the grid cells mapped with the multibeam echosounder was similar to that computed using the single-beam echosounder points (table 19). The mean error of the lidar data points compared with the ADCP data at East Branch Reservoir was $-0.24 \mathrm{ft}$, and the 95 percent accuracy was $0.78 \mathrm{ft}$. The mean error of the lidar data points compared with those from the single-beam echosounder was very close to 0 , and the computed 95 percent accuracy was about $1 \mathrm{ft}$, similar to that calculated for the multibeam echosounder data. As was observed in the comparison of single-beam echosounder data and multibeam echosounder data (table 20), the 95-percent accuracy of the lidar data points compared with those from the single-beam echosounder was better in flat areas than in steep areas: for example, accuracy of $0.47 \mathrm{ft}$ in areas with slope less than $1^{\circ}$ compared with $3.93 \mathrm{ft}$ in areas with slope of $30^{\circ}$ to $40^{\circ}$. Additionally, the steeper the slope of the mapped surface, the larger the mean error, with the single-beam echosounder points, especially, plotting on average shallower than the lidar data points in steeper areas (table 20, negative mean errors).

Table 18. Accuracy assessment of elevations of GNSS points compared with mapped raster surfaces for Boyd Corners Reservoir.

[Locations of reservoirs shown on figure 1. Survey data are available in Nystrom and others (2021). Each GNSS point was compared to the corresponding elevation of mapped raster; $\mathrm{RMSE}_{z}$, vertical root mean square error; accuracy ${ }_{z}$, National Standard for Spatial Data Accuracy fundamental vertical accuracy calculated at the 95-percent confidence level; lidar, light detection and ranging]

\begin{tabular}{lccccc}
\hline Grid cell data source & Number of points & $\begin{array}{c}\text { Mean error, } \\
\text { in feet }\end{array}$ & $\begin{array}{c}\text { Median error, } \\
\text { in feet }\end{array}$ & $\begin{array}{c}\text { RMSE }_{\mathbf{z}^{\prime}} \\
\text { in feet }\end{array}$ & $\begin{array}{c}\text { Accuracy }_{\mathbf{z}^{\prime}} \\
\text { in feet }\end{array}$ \\
\hline Overall & 185 & -0.21 & -0.02 & 0.88 & 1.72 \\
Multibeam echosounder & 139 & -0.02 & 0.02 & 0.44 & 0.86 \\
Lidar & 2 & -0.76 & -0.76 & 0.78 \\
Interpolated & 44 & -0.78 & -0.87 & 1.52 \\
\hline
\end{tabular}


Table 19. Accuracy assessment of elevations of lidar points compared with mapped raster surfaces and single-beam echosounder points at Bog Brook and East Branch Reservoirs in Putnam County, New York.

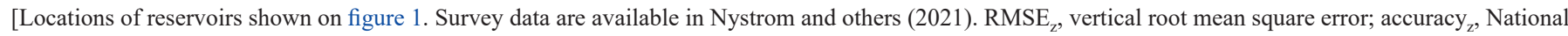
Standard for Spatial Data Accuracy fundamental vertical accuracy calculated at the 95-percent confidence level; ADCP, acoustic Doppler current profiler]

\begin{tabular}{|c|c|c|c|c|c|}
\hline Data source & Number of points & $\begin{array}{c}\text { Mean error, } \\
\text { in feet }\end{array}$ & $\begin{array}{l}\text { Median error, } \\
\text { in feet }\end{array}$ & $\begin{array}{l}\text { RMSE }_{z^{\prime}} \\
\text { in feet }\end{array}$ & $\begin{array}{l}\text { Accuracy }_{z^{\prime}} \\
\text { in feet }\end{array}$ \\
\hline \multicolumn{6}{|c|}{ Bog Brook Reservoir } \\
\hline Interpolated grid cell & 8,229 & 0.07 & 0.06 & 0.38 & 0.74 \\
\hline Single-beam echosounder points & 2,103 & -0.02 & 0.06 & 0.49 & 0.96 \\
\hline ADCP grid cell & 3,947 & -0.24 & -0.27 & 0.4 & 0.78 \\
\hline Interpolated grid cell & 69,090 & -0.32 & -0.31 & 0.56 & 1.09 \\
\hline Single-beam echosounder points & 3,533 & 0.02 & 0.08 & 0.57 & 1.11 \\
\hline
\end{tabular}

Table 20. Accuracy assessment of elevations of lidar points compared with mapped multibeam raster cells and single-beam echosounder points, categorized by slope, at Bog Brook and East Branch Reservoirs in Putnam County, New York.

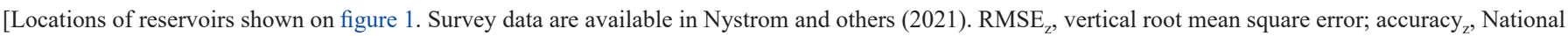
Standard for Spatial Data Accuracy fundamental vertical accuracy calculated at the 95-percent confidence level; >, greater than]

\begin{tabular}{|c|c|c|c|c|c|}
\hline $\begin{array}{c}\text { Slope, } \\
\text { in degrees }\end{array}$ & Number of points & $\begin{array}{c}\text { Mean error, } \\
\text { in feet }\end{array}$ & $\begin{array}{l}\text { Median error, } \\
\text { in feet }\end{array}$ & $\begin{array}{l}\text { RMSE }_{z^{\prime}} \\
\text { in feet }\end{array}$ & $\begin{array}{c}\text { Accuracy }_{z^{\prime}} \\
\text { in feet }\end{array}$ \\
\hline \multicolumn{6}{|c|}{ Multibeam echosounder grid cells } \\
\hline$>1$ to 10 & $1,288,376$ & 0.32 & 0.33 & 0.42 & 0.83 \\
\hline$>10$ to 20 & 452,867 & 0.33 & 0.34 & 0.51 & 1 \\
\hline$>40$ to 50 & 1,367 & -0.08 & 0.04 & 1.48 & 2.91 \\
\hline$>50$ to 60 & 338 & -0.5 & -0.41 & 2.3 & 4.5 \\
\hline \multicolumn{6}{|c|}{ Single-beam echosounder points } \\
\hline 0 to 1 & 246 & 0.04 & 0.05 & 0.24 & 0.47 \\
\hline$>30$ to 40 & 31 & -1.59 & -1.9 & 2 & 3.93 \\
\hline
\end{tabular}




\section{Summary}

New York City's 16 East of Hudson reservoirs and controlled lakes were surveyed by the U.S. Geological Survey, in cooperation with the New York City Department of Environmental Conservation from May 2017 to November 2019 using a multibeam echosounder from a moving boat. Multibeam data were supplemented with acoustic Doppler current profiler data in some areas without boat ramps and with light detection and ranging (lidar) data above the water surface elevation. Quality-assurance datasets included single-beam echosounder data, global navigation satellite system (GNSS) point data, and lidar point data.

A Teledyne Odom MB2 multibeam echosounder with an integrated inertial navigation system using real-time sound velocity measurement at the transducer head was used to collect multibeam data. Patch tests were performed to calibrate the inertial navigation system. Sound velocity profiles were measured to correct echosounder data for stratification with depth. The multibeam data were processed to include corrections for sound velocity, conversion of depth to elevation using a time series of water surface elevation, and to remove erroneous points. Following multibeam data processing and editing, almost 3.7 billion point observations remained. Multibeam echosounder data, ADCP data, and lidar data were combined to create 3.28-foot raster grids for each lake. Estimated points were used to represent unmeasurable areas (for example, near structures and islands) in the grids. Grid cells with no data from these sources were interpolated from surrounding data, and additional estimated points were used to improve the interpolation of bathymetric surfaces. Bathymetric contours at 2 -foot intervals of elevation and elevation-area-capacity tables were computed from the raster grid. The geospatial bathymetric data and results are available as a USGS data release.

The results of the bathymetric survey indicate that New York City's EOH reservoirs and controlled lakes are between about 25 and more than 160 feet deep and have a total capacity of about 142.9 billion gallons at full spillway level and a combined surface area of more than 11,600 acres. The accuracy of the mapped raster grids was evaluated using a quality assurance dataset collected with a single-beam echosounder; about 280,000 quality assurance points were spatially joined with the mapped raster surfaces in a geographic information system, and the measured elevations were compared. The calculated mean elevation error for the East of Hudson reservoirs was 0.35 foot, the median error was 0.21 foot, and the 95 -percent accuracy was 1.68 feet; the 95-percent accuracy of the computed capacity at spillway elevation was 1.6 percent or less.

\section{References Cited}

AML Oceanographic, 2010, Smart SV user manual (ver. 2.1, January 13, 2010): AML Oceanographic, 22 p., accessed October 26, 2020, at https://amloceanographic.com/ documents/\#1147-1130-wpfd-traditional-instruments.

Applanix Corp., 2017, POS MV V5 installation and operation guide, rev. 17: Richmond Hill, Ontario, Canada, Applanix Corp. PUBS-MAN-004291, 293 p., accessed October 5, 2016, at https://amloceanographic.app.boxenterprise.net/ web_links/3328063/shared/a1qjym370915odho0683.

Esri Inc., 2020, ArcGIS Desktop: Esri Inc. software, accessed October 27, 2020, at https://www.esri.com/en-us/arcgis/ products/arcgis-desktop/overview.

Federal Geographic Data Committee, 1998, National standard for spatial data accuracy, pt. 3 of Geospatial positioning accuracy standards: Federal Geographic Data Committee FGDC-STD-007.3, p. 3-1-3-25, accessed February 14, 2021, at https://www.fgdc.gov/standards/projects/accuracy/ part3/chapter3.

Helsel, D.R., Hirsch, R.M., Ryberg, K.R., Archfield, S.A., and Gilroy, E.J., 2020, Statistical methods in water resources: U.S. Geological Survey Techniques and Methods, book 4, chap. A3, 458 p., accessed June 23, 2020, at https://doi.org/ $10.3133 / \mathrm{tm} 4 \mathrm{a} 3$.

Hemisphere, G.N.S.S., Inc., 2017, V102 GPS Compass user guide: Hemisphere GNSS, Inc. Part 875-0276-000 Rev C2, 60 p., accessed February 14, 2021, at https://www .hemispheregnss.com/wp-content/uploads/2018/12/ hemispheregnss_v102_userguide_875-0276-000_c2-1.pdf.

Huizinga, R.J., 2016, Bathymetric and velocimetric surveys at highway bridges crossing the Missouri River near Kansas City, Missouri, June 2-4, 2015: U.S. Geological Survey Scientific Investigations Report 2016-5061, 93 p., accessed June 23, 2020, at https://doi.org/10.3133/sir20165061.

Huizinga, R.J., and Heimann, D.C., 2018, Hydrographic surveys of rivers and lakes using a multibeam echosounder mapping system: U.S. Geological Survey Fact Sheet 2018-3021, 6 p., accessed June 23, 2020, at https://doi.org/ $10.3133 /$ fs 20183021 .

HYPACK, 2021, New releases \& program updates: HYPACK web page, accessed February 14, 2021, at https://www.h ypack.com/customer-support/programs-and-updates.

National Marine Electronics Association, 2002, Standard for interfacing marine electronic devices (ver. 3.01): National Marine Electronics Association standard NMEA 0183, 88 p., accessed June 23, 2020, at https://www.plaisancepratique.com/IMG/pdf/NMEA0183-2.pdf. 
New York City Department of Environmental Protection (NYCDEP), 2009, East of Hudson lidar data: New York City Department of Environmental Protection data, accessed March 24, 2020, at ftp://ftp.gis.ny.gov/elevation/ LIDAR/NYCDEP_EastOfHudson2009/2009_EOH.xml.

New York City Department of Environmental Protection (NYCDEP), 2020a, History of New York City drinking water: New York City Department of Environmental Protection web page, accessed October 6, 2020, at https://www1.nyc.gov/site/dep/water/history-of-new-yorkcitys-drinking-water.page.

New York City Department of Environmental Protection (NYCDEP), 2020b, New York City drinking water supply and quality report-2019: New York City Department of Environmental Protection, 20 p., accessed October 6, 2020, at https://www1.nyc.gov/assets/dep/downloads/pdf/water/ drinking-water/drinking-water-supply-quality-report/2019drinking-water-supply-quality-report.pdf.

New York City Department of Environmental Protection (NYCDEP), 2021a, Amawalk Reservoir: New York City Department of Environmental Protection web page, accessed February 14, 2021, at https://www1.nyc.gov/site/ dep/water/amawalk-reservoir.page.

New York City Department of Environmental Protection (NYCDEP), 2021b, Bog Brook Reservoir: New York City Department of Environmental Protection web page, accessed February 14, 2021, at https://www1.nyc.gov/site/ dep/water/bog-brook-reservoir.page.

New York City Department of Environmental Protection (NYCDEP), 2021c, Boyd Corners Reservoir: New York City Department of Environmental Protection web page, accessed February 14, 2021, at https://www1.nyc.gov/site/ dep/water/boyds-corner-reservoir.page.

New York City Department of Environmental Protection (NYCDEP), 2021d, Cross River Reservoir: New York City Department of Environmental Protection web page, accessed February 14, 2021, at https://www1.nyc.gov/site/ dep/water/cross-river-reservoir.page.

New York City Department of Environmental Protection (NYCDEP), 2021e, Croton Falls Reservoir: New York City Department of Environmental Protection web page, accessed February 14, 2021, at https://www1.nyc.gov/site/ $\mathrm{dep} /$ water/croton-falls-reservoir.page.

New York City Department of Environmental Protection (NYCDEP), 2021f, Diverting Reservoir: New York City Department of Environmental Protection web page, accessed February 14, 2021, at https://www1.nyc.gov/site/ dep/water/diverting-reservoir.page.
New York City Department of Environmental Protection (NYCDEP), 2021g, East Branch Reservoir: New York City Department of Environmental Protection web page, accessed February 14, 2021, at https://www1.nyc.gov/site/ dep/water/east-branch-reservoir.page.

New York City Department of Environmental Protection (NYCDEP), 2021h, Kensico Reservoir: New York City Department of Environmental Protection web page, accessed February 14, 2021, at https://www1.nyc.gov/site/ dep/water/kensico-reservoir.page.

New York City Department of Environmental Protection (NYCDEP), 2021i, Middle Branch Reservoir: New York City Department of Environmental Protection web page, accessed February 14, 2021, at https://www1.nyc.gov/site/ dep/water/middle-branch-reservoir.page.

New York City Department of Environmental Protection (NYCDEP), 2021j, Muscoot Reservoir: New York City Department of Environmental Protection web page, accessed February 14, 2021, at https://www1.nyc.gov/site/ dep/water/muscoot-reservoir.page.

New York City Department of Environmental Protection (NYCDEP), 2021k, New Croton Reservoir: New York City Department of Environmental Protection web page, accessed February 14, 2021, at https://www1.nyc.gov/site/ dep/water/new-croton-reservoir.page.

New York City Department of Environmental Protection (NYCDEP), 20211, Titicus Reservoir: New York City Department of Environmental Protection web page, accessed February 14, 2021, at https://www1.nyc.gov/site/ dep/water/titicus-reservoir.page.

New York City Department of Environmental Protection (NYCDEP), 2021m, West Branch Reservoir: New York City Department of Environmental Protection web page, accessed February 14, 2021, at https://www1.nyc.gov/site/ dep/water/west-branch-reservoir.page.

New York State Department of Transportation, 2021, NYSNet spatial reference network (CORS/real time network): New York State Department of Transportation web page, accessed February 9, 2021, at https://www.dot.ny.gov/ divisions/engineering/design/design-services/landsurvey/cors.

Nystrom, E.A., 2018, Bathymetry of Ashokan, Cannonsville, Neversink, Pepacton, Rondout, and Schoharie reservoirs, New York, 2013-15: U.S. Geological Survey Scientific Investigations Report 2017-5064, 29 p., accessed June 23, 2020, at https://doi.org/10.3133/sir20175064. 
Nystrom, E.A., and Collenburg, J.V., 2020, Bathymetry of Morris Lake (Newton Reservoir), New Jersey, 2018: U.S. Geological Survey Scientific Investigations Report 2020-5010, 14 p., accessed June 23, 2020, at https://doi.org/ 10.3133/sir20205010.

Nystrom, E.A., Huston, C.J., and Welk, R.J., 2021, Geospatial bathymetry datasets for New York City's East of Hudson reservoirs and controlled lakes: U.S. Geological Survey data release, https://doi.org/10.5066/P9ZZQ2OT.

SyQwest, Inc., 2008, Bathy-500MF multi frequency-survey echosounder: SyQwest, Inc. installation, operation, and maintenance manual, 58 p., accessed February 14, 2021, at https://www.syqwestinc.com/media/bathy-500mf/ bathy500mf-manual.pdf.

Teledyne Marine, 2016, Introducing RioPro-Your Rio Grande upgrade path: Teledyne Marine news, September 1, 2016, accessed February 10, 2021, at http://www.teledynem arine.com/news/RDI_RioPro_Upgrade.

Teledyne Marine, 2020, WinRiver II software user's guide: Teledyne Marine, 318 p., accessed March 3, 2021, at http://www.teledynemarine.com/Documents/Brand $\% 20$ Support/RD\%20INSTRUMENTS/Technical\%20Resources/ Manuals\%20and\%20Guides/Workhorse/WinRiver\% 20II\%20User\%20Guide_Mar20.pdf.

Teledyne Marine Odom Hydrographic, 2021, MB2 multibeam echosounder: Teledyne Marine Odom Hydrographic product datasheet, 2 p., accessed February 14, 2021, at http://www .teledynemarine.com/Lists/Downloads/Odom/Teledyne $\% 20$ Odom\%20MB2\%20product $\% 20$ leaflet.pdf.

Teledyne PDS, 2019, Teledyne PDS version 4.3.12: Teledyne PDS user manual, 869 p., accessed March 2, 2021, at http://www.teledynemarine.com/Lists/Downloads/P DS\%20leaflets\%20and\%20manuels/PDS\%20Manuals/ Teledyne\%20PDS\%20User\%20Manual.pdf.
Teledyne PDS, 2021a, Multibeam survey and processing/ charting: Teledyne PDS leaflet, 2 p., accessed February 14, 2021, at http://www.teledynemarine.com/Lists/Downloads/P DS\%20leaflets\%20and\%20manuels/Multibeam\%20Survey $\% 20$ and $\% 20$ Processing-Charting product $\% 20$ leaflet.pdf.

Teledyne PDS, 2021b, PDS multibeam survey and processing/ charting: Teledyne PDS web page, accessed May 5, 2021, at http://www.teledynemarine.com/pds-multibeam-surveyand-processing-charting.

Teledyne RESON, 2021, SVP 70-Fixed-mount sound velocity probe: Teledyne RESON product leaflet, 2 p., accessed February 14, 2021, at http://www.teledynemarine.com/Lists/ Downloads/SVP_70_\%20product\%20leaflet.pdf.

Trimble Inc., 2009, Trimble R8 GNSS receiver Trimble R6/5800 GPS receiver: Trimble Inc. user guide, 86 p., accessed February 14, 2021, at http://trl.tr imble.com/docushare/dsweb/Get/Document-666215/R8-R65800_v400A_UserGuide.pdf.

Trimble Inc., 2021, Trimble Business Center-Office software for surveyors: Trimble Inc. web page, accessed February 14, 2021, at https://geospatial.trimble.com/products-andsolutions/trimble-business-center.

Wilson, G.L., and Richards, J.M., 2006, Procedural documentation and accuracy assessment of bathymetric maps and area/capacity tables for small reservoirs: U.S. Geological Survey Scientific Investigations Report 2006-5208, 24 p., oversized figs., accessed June 23, 2020, at https://doi.org/ 10.3133/sir20065208. 

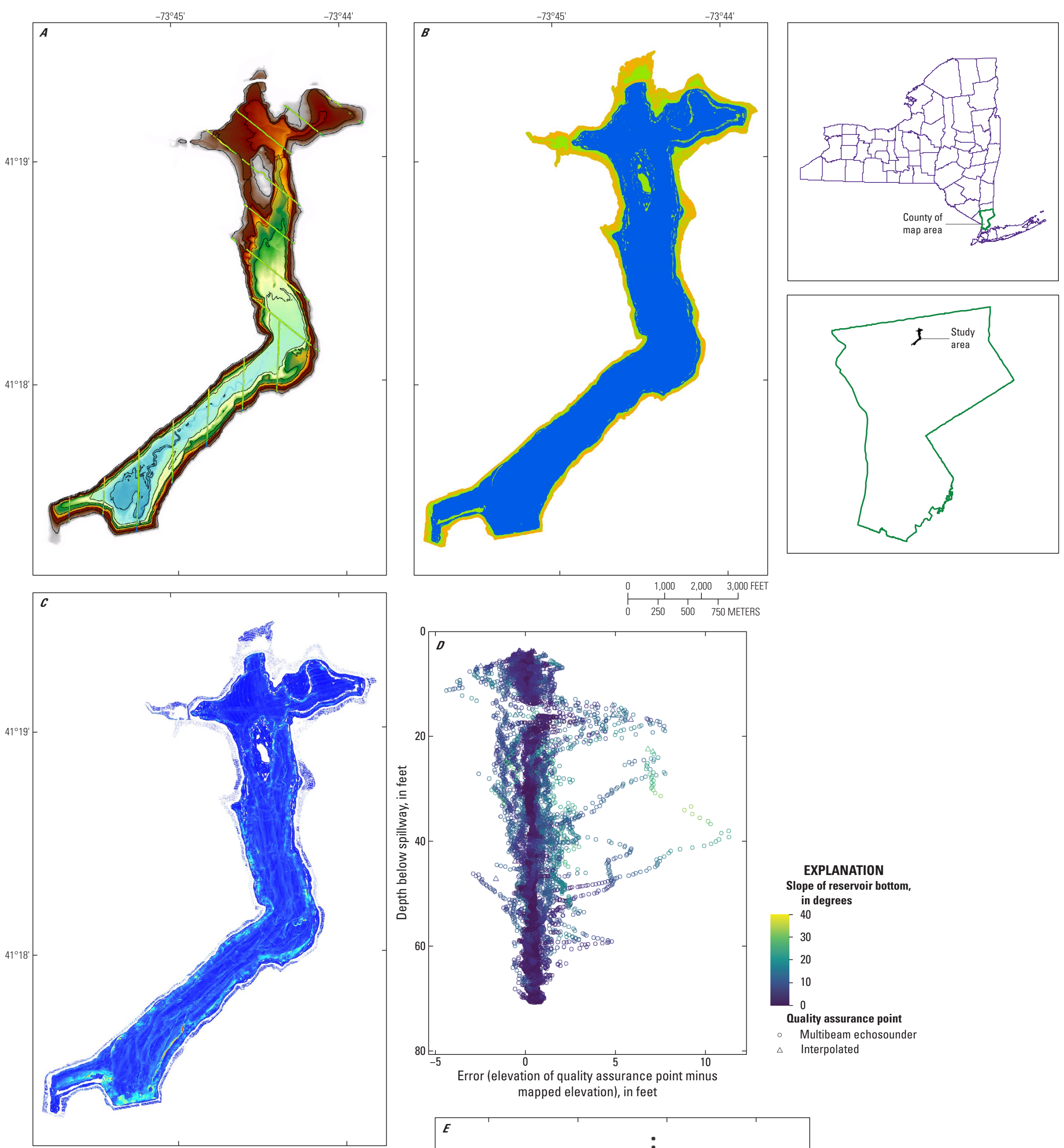

\begin{tabular}{|cc}
$\begin{array}{c}\text { EXPLANATION } \\
\text { Elevation, in feet above } \\
\text { NAVD } 88\end{array}$ & $\begin{array}{c}\text {-10-foot contour interval } \\
\text { Quality assurance point } \\
\text { elevation minus grid } \\
\text { elevation, in feet }\end{array}$ \\
\hline High : 398.32 & -4.38 to -2.20 \\
\hline Low : 323.95 & -2.21 to -1.00 \\
Standard deviation of & -0.99 to -0.50 \\
elevation values & -0.49 to 0.00 \\
within grid cell, & 0.01 to 0.50 \\
in feet & 0.51 to 1.00 \\
High: 3 & 1.01 to 2.00 \\
\hline Low: 0 & 2.01 to 4.00 \\
Source of elevation data & 4.01 to 6.00 \\
in grid cell & 6.01 to 8.00 \\
\hline Multibeam echosounder & 8.01 to 11.30 \\
\hline Lidar & \\
\hline Estimated & \\
\hline Interpolated & \\
\hline
\end{tabular}

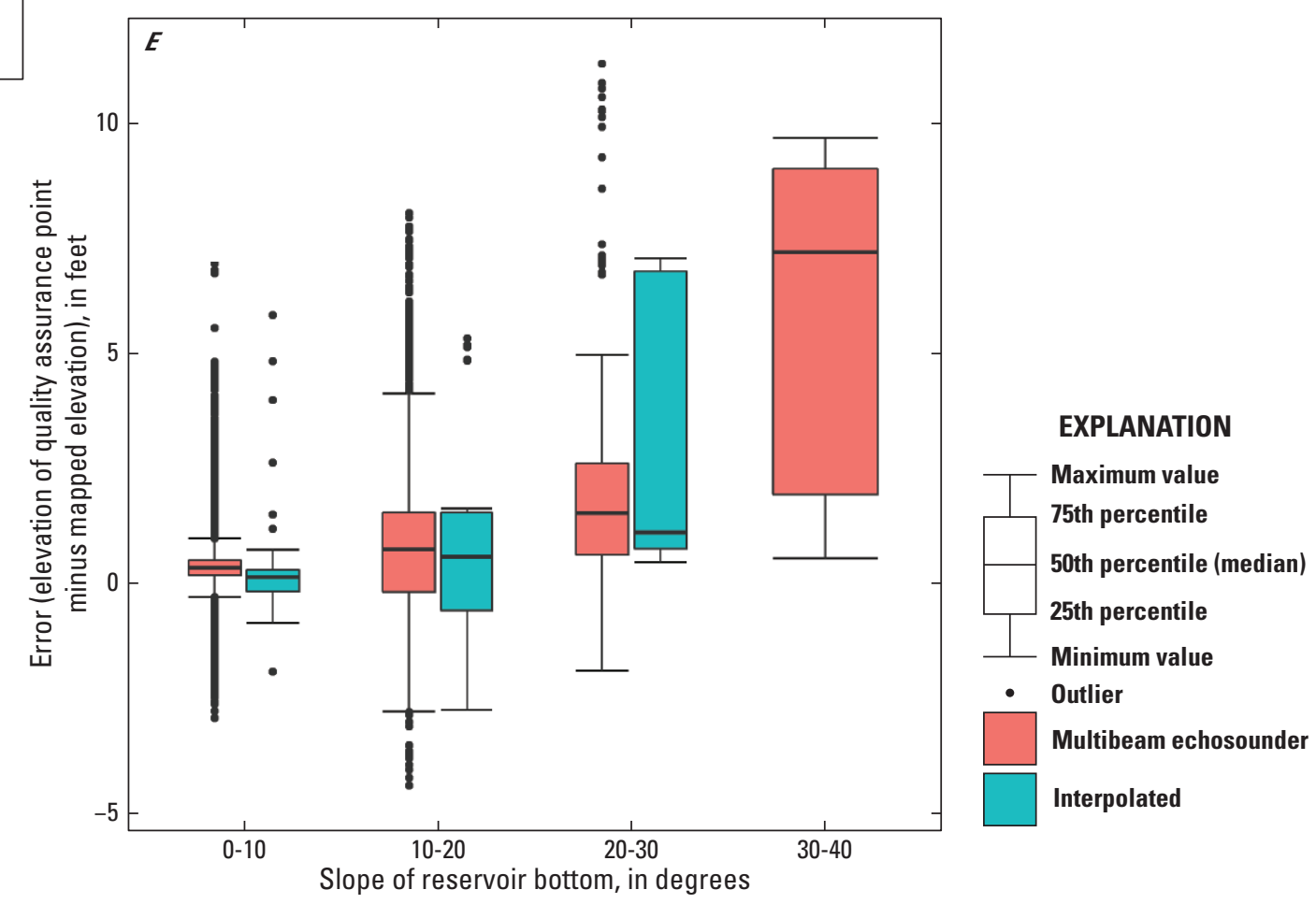

Figure 10. Results of bathymetric mapping of Amawalk Reservoir in Westchester County, New York, including maps of $A$, bathymetric elevations, contours, and quality assurance points, $B$, source data type, and $C$, cell standard deviation; and plots showing comparison of quality assurance points and mapped elevation $D$, by depth and slope and $E$, by grid cell data source. Mapped data are from Nystrom and others (2021). Lidar, light detection and ranging; NAVD 88; North American Vertical Datum of 1988. A large version of this figure is available for download at https://doi.org/10.3133/sir20215057. 

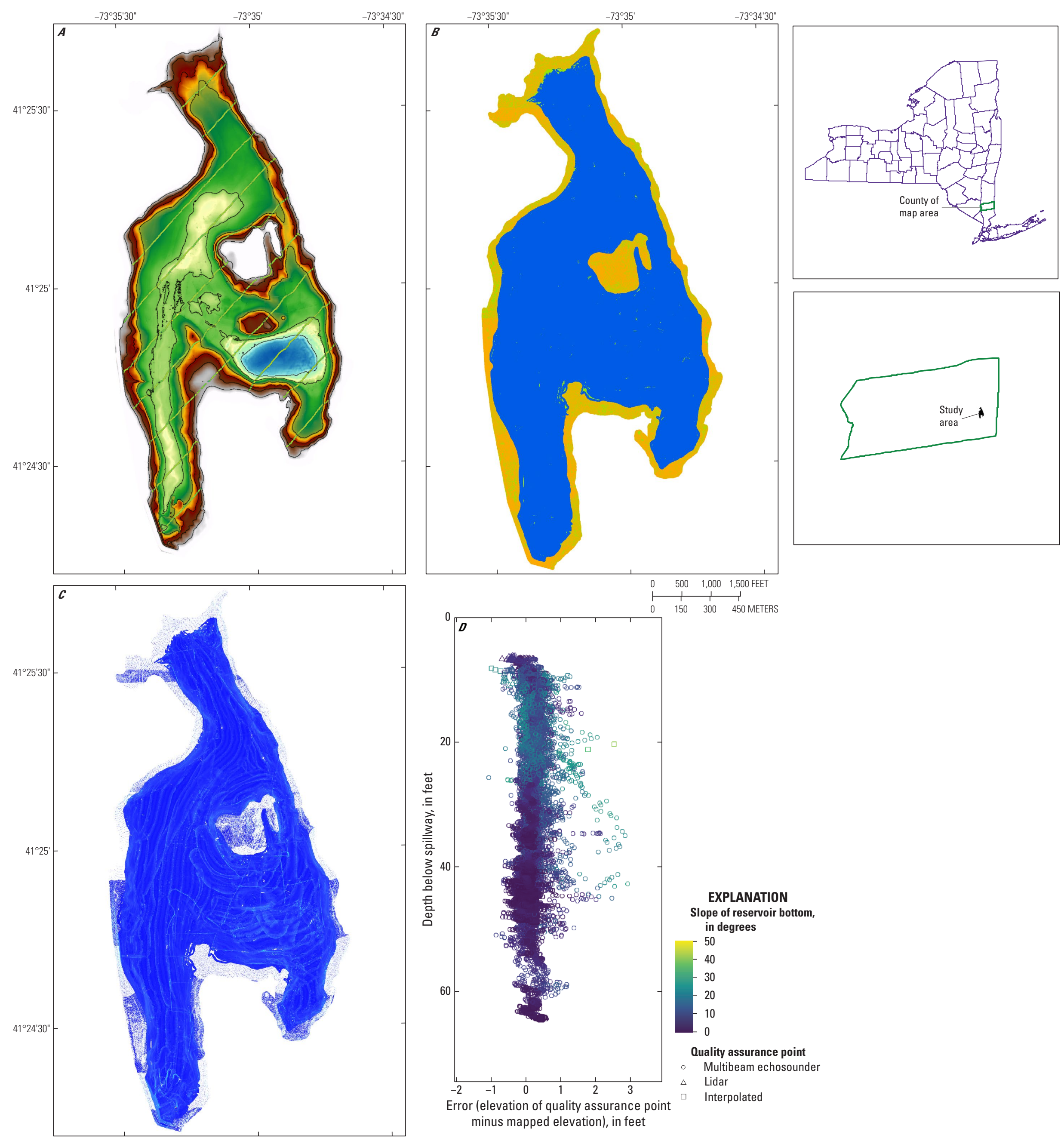

\section{EXPLANATION}

\begin{tabular}{c|c}
$\begin{array}{c}\text { Elevation, in feet above } \\
\text { NAVD } 88\end{array}$ & $\begin{array}{c}\text { 10-foot contour interval } \\
\text { Quality assurance point } \\
\text { elevation minus grid } \\
\text { elevation, in feet }\end{array}$ \\
\hline High : 415.54 & -3.00 to -2.20 \\
Low : 350.37 & -2.21 to -1.00 \\
Standard deviation of & -0.99 to -0.50 \\
elevation values & -0.49 to 0.00 \\
within grid cell, & 0.01 to 0.50 \\
in feet & 0.51 to 1.00 \\
\hline High: 3 & 1.01 to 2.00 \\
\hline Low: 0 & 2.01 to 4.00 \\
Source of elevation data & 4.01 to 6.00 \\
in grid cell & 6.01 to 8.00 \\
\hline Multibeam echosounder & 8.01 to 11.30 \\
\hline Lidar & \\
\hline Estimated & \\
\hline Interpolated & \\
\hline
\end{tabular}

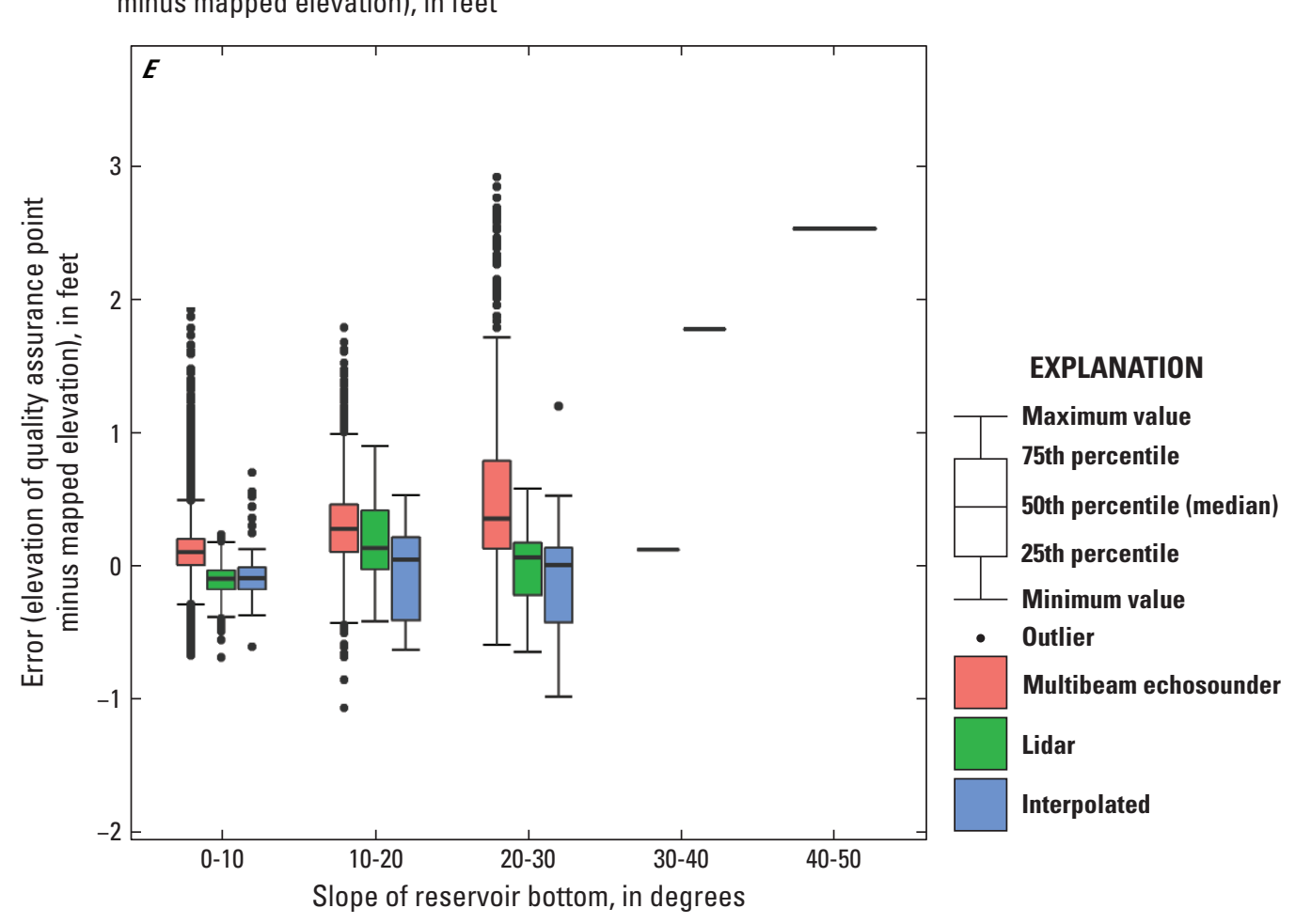

Figure 11. Results of bathymetric mapping of Bog Brook Reservoir in Putnam County, New York, including maps of $A$, bathymetric elevations, contours, and quality assurance points, $B$, source data type, and $C$, cell standard deviation; and plots showing comparison of quality assurance points and mapped elevation $D$, by depth and slope and $E$, by grid cell data source. Mapped data are from Nystrom and others (2021). Lidar, light detection and ranging; NAVD 88; North American Vertical Datum of 1988. A large version of this figure is available for download at https://doi.org/10.3133/sir20215057. 

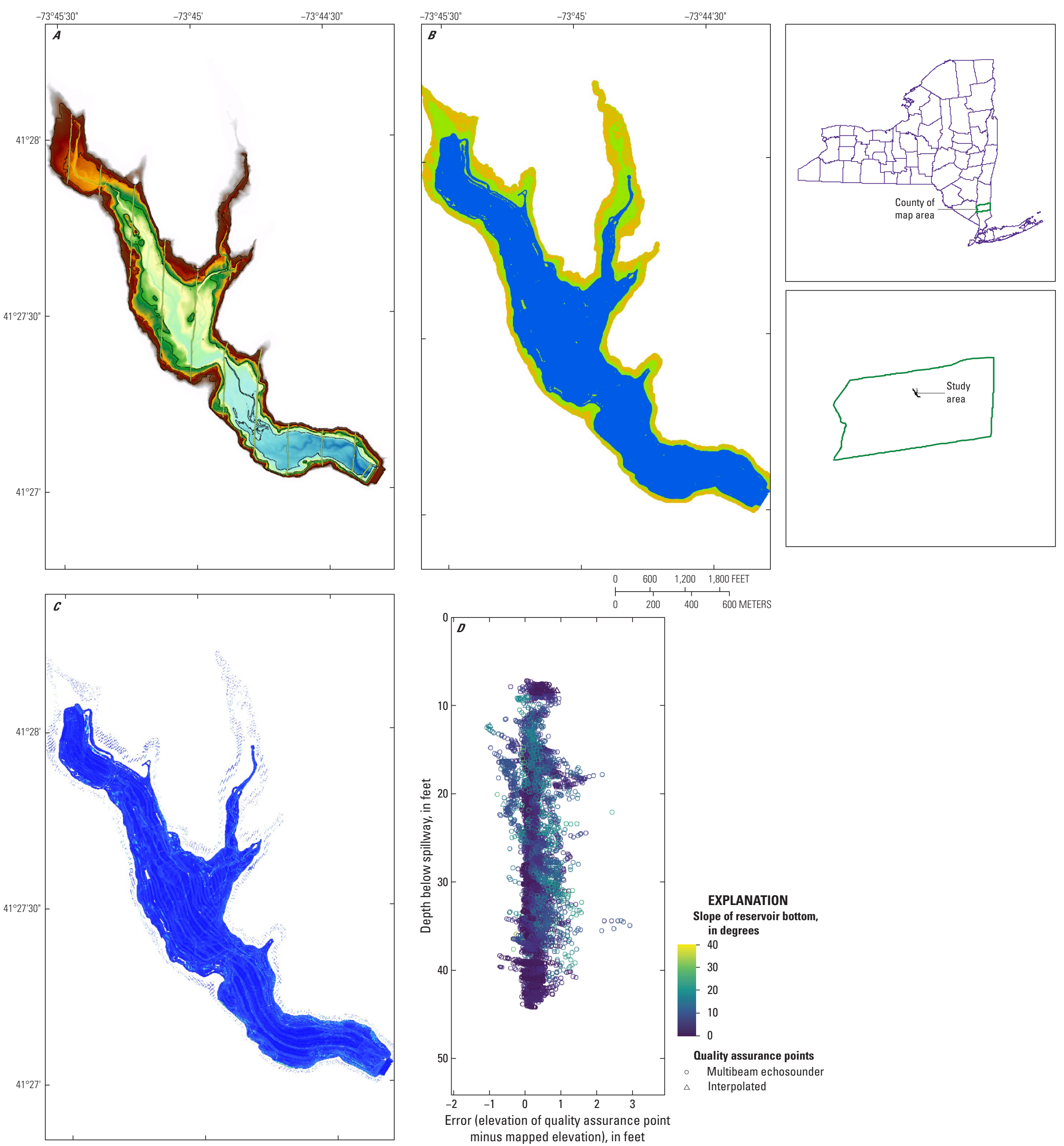

\begin{tabular}{|c|c|}
\hline \multicolumn{2}{|c|}{ EXPLANATION } \\
\hline $\begin{array}{l}\text { Elevation, in feet above } \\
\text { NAVD } 88 \\
\text { - High : } 579.29\end{array}$ & $\begin{array}{l}\text {-10-foot contour interval } \\
\text { Quality assurance point } \\
\text { elevation minus grid } \\
\text { elevation, in feet }\end{array}$ \\
\hline Low: 535.05 & $\quad-3.00$ to -2.22 \\
\hline Standard deviation of & -2.21 to -1.00 \\
\hline elevation values & -0.99 to -0.50 \\
\hline within grid cell, & -0.49 to 0.00 \\
\hline in feet & 0.01 to 0.50 \\
\hline High: 3 & 0.51 to 1.00 \\
\hline & 1.01 to 2.00 \\
\hline Low: 0 & 2.01 to 4.00 \\
\hline Source of elevation data & 4.01 to 6.00 \\
\hline in grid cell & 6.01 to 8.00 \\
\hline Multibeam echosounder & 8.01 to 9.00 \\
\hline $\begin{array}{l}Z \text { Lidar } \\
\text { Estimated }\end{array}$ & \\
\hline Interpolated & \\
\hline
\end{tabular}

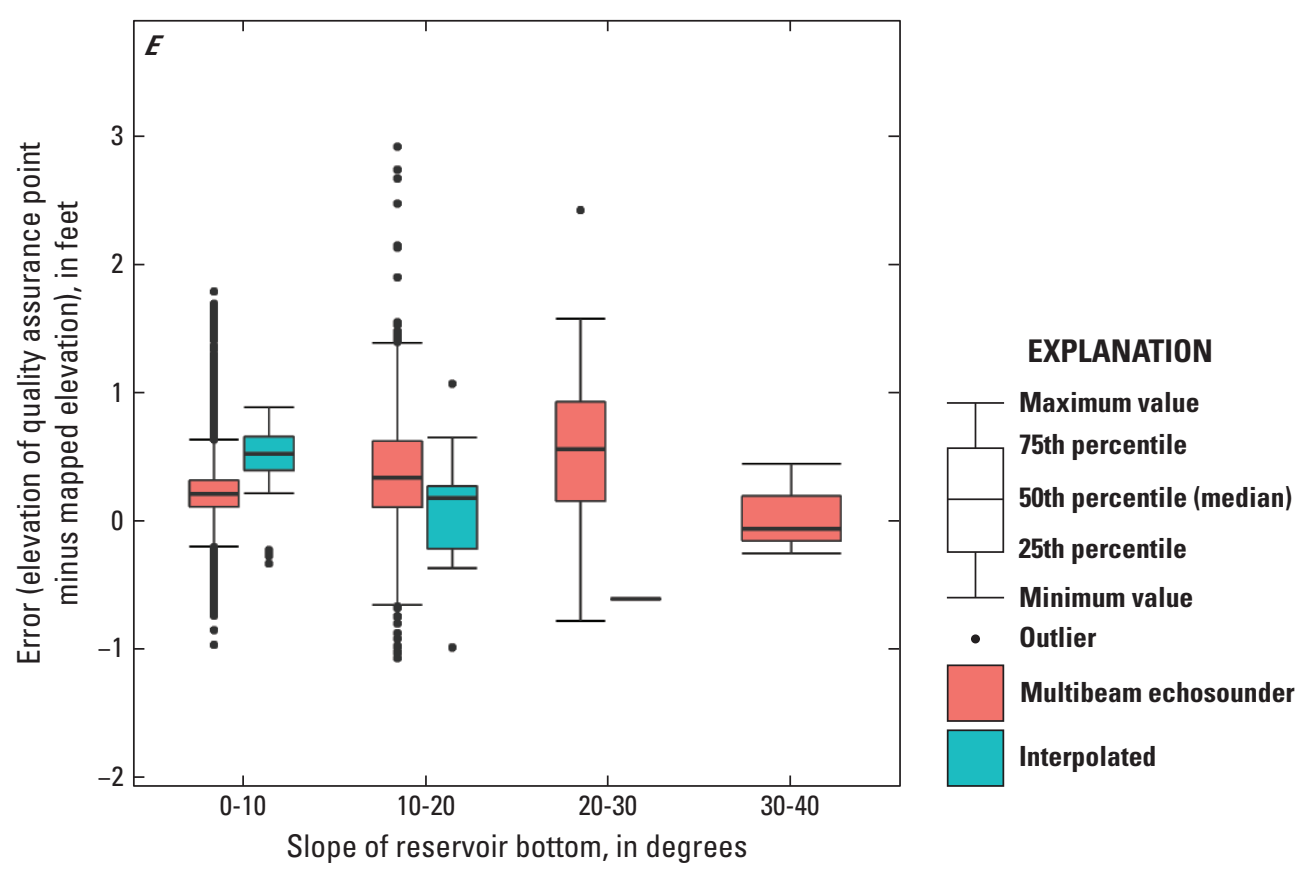

Figure 12. Results of bathymetric mapping of Boyd Corners Reservoir in Putnam County, New York, including maps of $A$, bathymetric elevations, contours, and quality assurance points, $B$, source data type, and $C$, cell standard deviation; and plots showing comparison of quality assurance points and mapped elevation $D$, by depth and slope and $E$, by grid cell data source. Mapped data are from Nystrom and others (2021). Lidar, light detection and ranging; NAVD 88; North American Vertical Datum of 1988. A large version of this figure is available for download at https://doi.org/10.3133/sir20215057. 

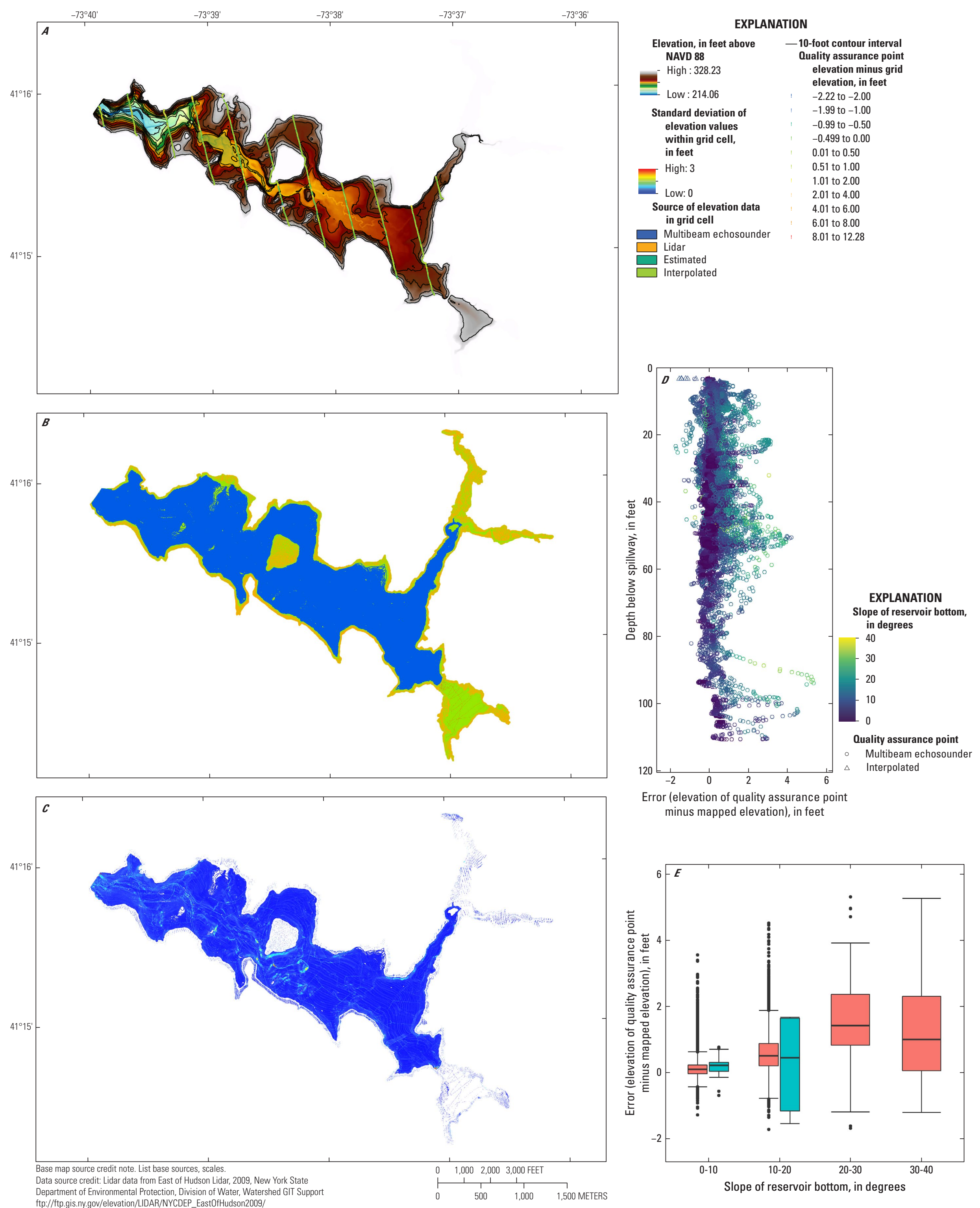

\begin{tabular}{|c|c|}
\hline \multicolumn{2}{|c|}{ EXPLANATION } \\
\hline $\begin{array}{l}\text { Elevation, in feet above } \\
\text { NAVD } 88 \\
\text { - High : } 328.23 \\
\end{array}$ & $\begin{array}{l}\text {-10-foot contour interval } \\
\text { Quality assurance poin } \\
\text { elevation minus grid } \\
\text { elevation, in feet }\end{array}$ \\
\hline Low: 214.06 & -2.22 to -2.00 \\
\hline Standard deviation of & -1.99 to -1.00 \\
\hline & -0.99 to -0.50 \\
\hline within grid cell, & -0.499 to 0.00 \\
\hline & 0.01 to 0.50 \\
\hline High: 3 & 0.51 to 1.00 \\
\hline & 1.01 to 2.00 \\
\hline Low: 0 & 2.01 to 4.00 \\
\hline Source of elevation data & 4.01 to 6.00 \\
\hline in grid cell & 6.01 to 8.00 \\
\hline $\begin{array}{l}\text { Muttibeam echosounder } \\
\text { Lidar }\end{array}$ & 8.01 to 12.28 \\
\hline Estimated & \\
\hline
\end{tabular}
Group, available online at

[All other data original to this study]
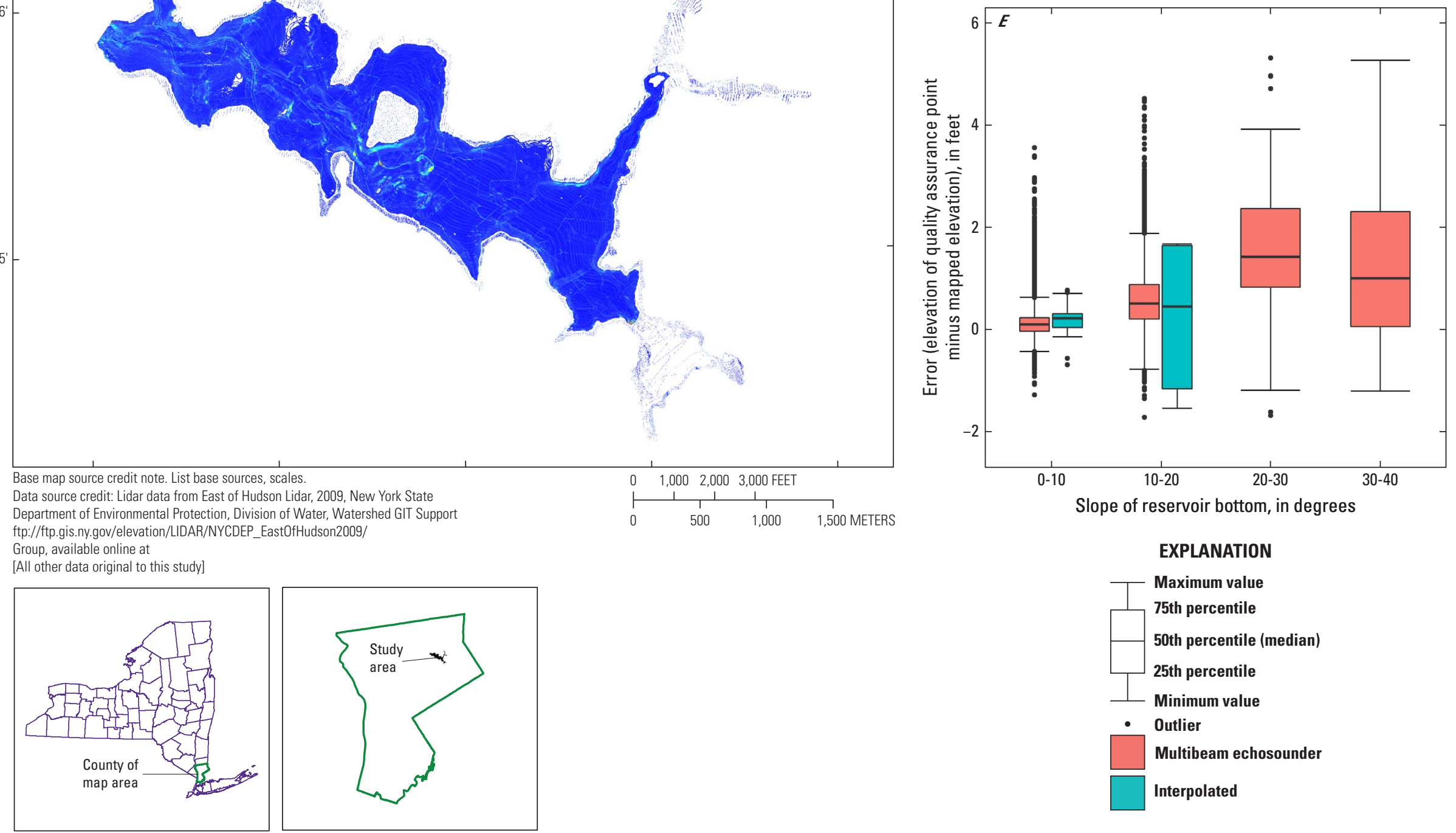

Figure 13. Results of bathymetric mapping of Cross River Reservoir in Westchester County, New York, including maps of $A$, bathymetric elevations, contours, and quality assurance points, $B$, source data type, and $C$, cell standard deviation; and plots showing comparison of quality assurance points and mapped elevation $D$, by depth and slope and $E$, by grid cell data source. Mapped data are from Nystrom and others (2021). Lidar, light detection and ranging; NAVD 88; North American Vertical Datum of 1988. A large version of this figure is available for download at https://doi.org/10.3133/sir20215057. 

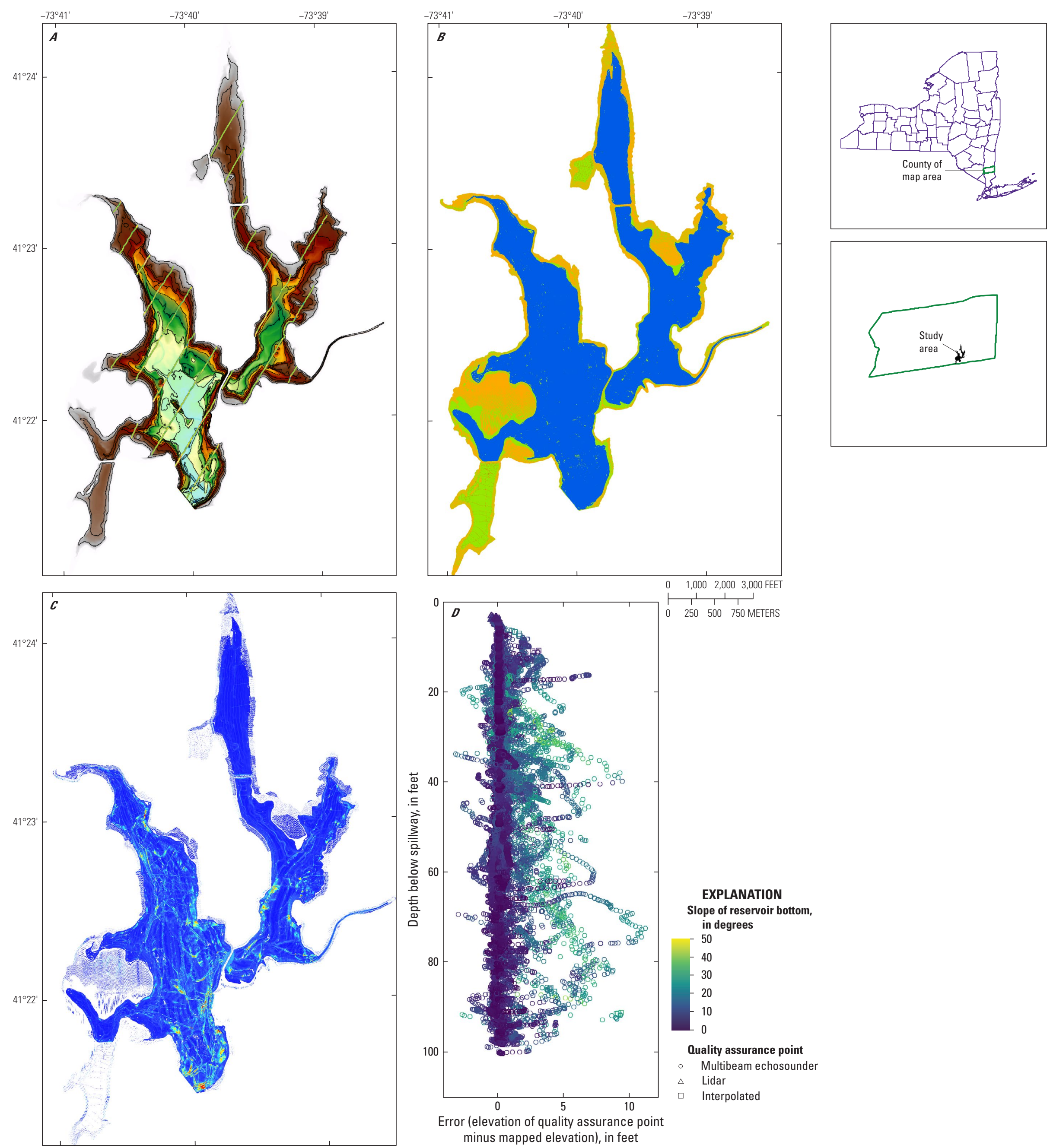

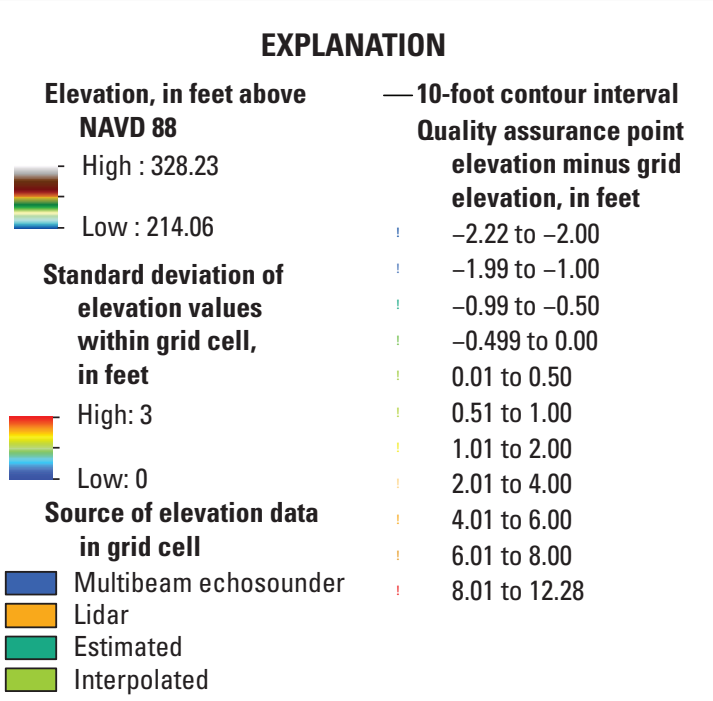

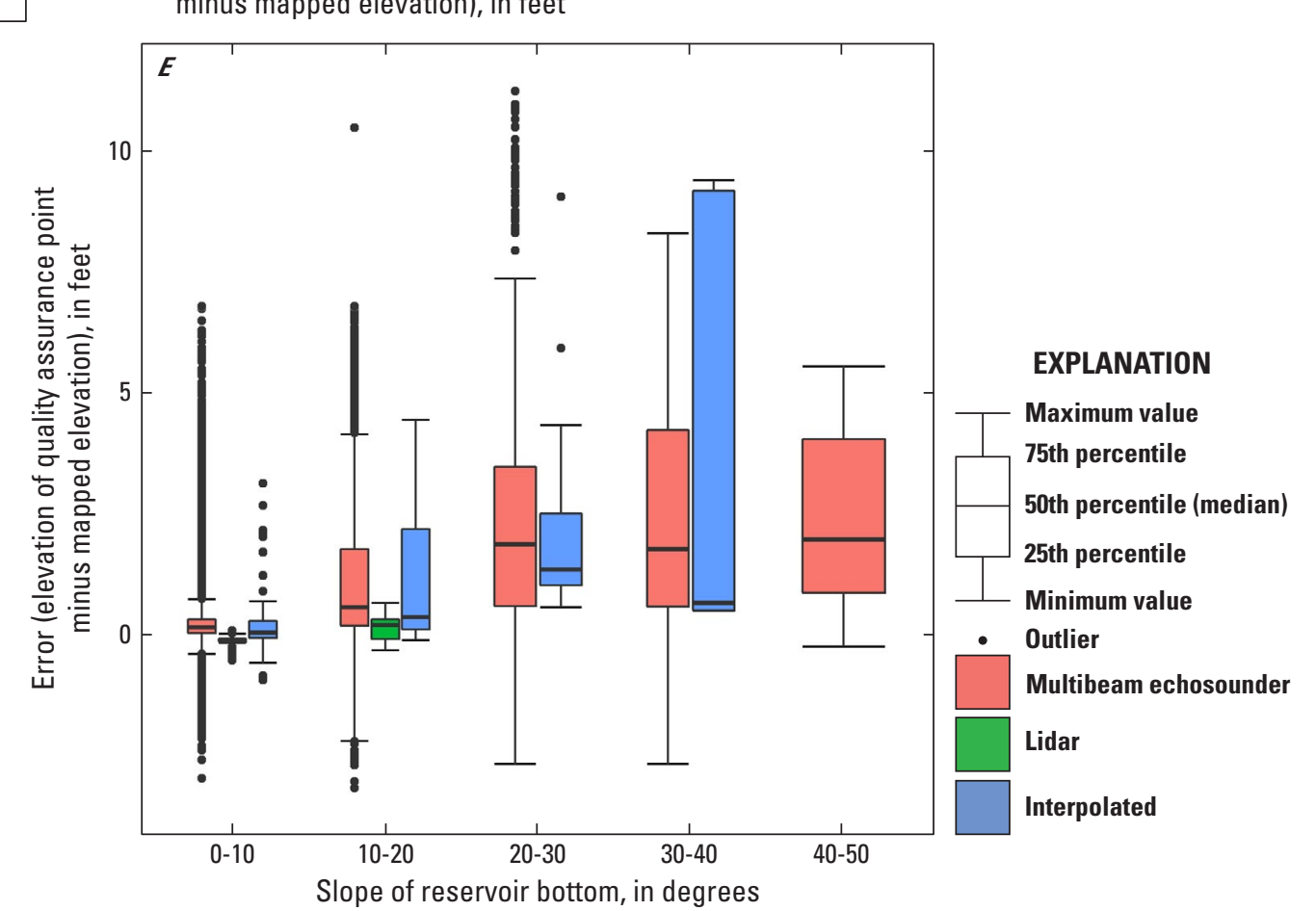

Figure 14. Results of bathymetric mapping of Croton Falls Reservoir in Putnam County, New York, including maps of $A$, bathymetric elevations, contours, and quality assurance points, $B$, source data type, and $C$, cell standard deviation; and plots showing comparison of quality assurance points and mapped elevation $D$, by depth and slope and $E$, by grid cell data source. Mapped data are from Nystrom and others (2021). Lidar, light detection and ranging; NAVD 88; North American Vertical Datum of 1988. A large version of this figure is available for download at https://doi.org/10.3133/sir20215057. 

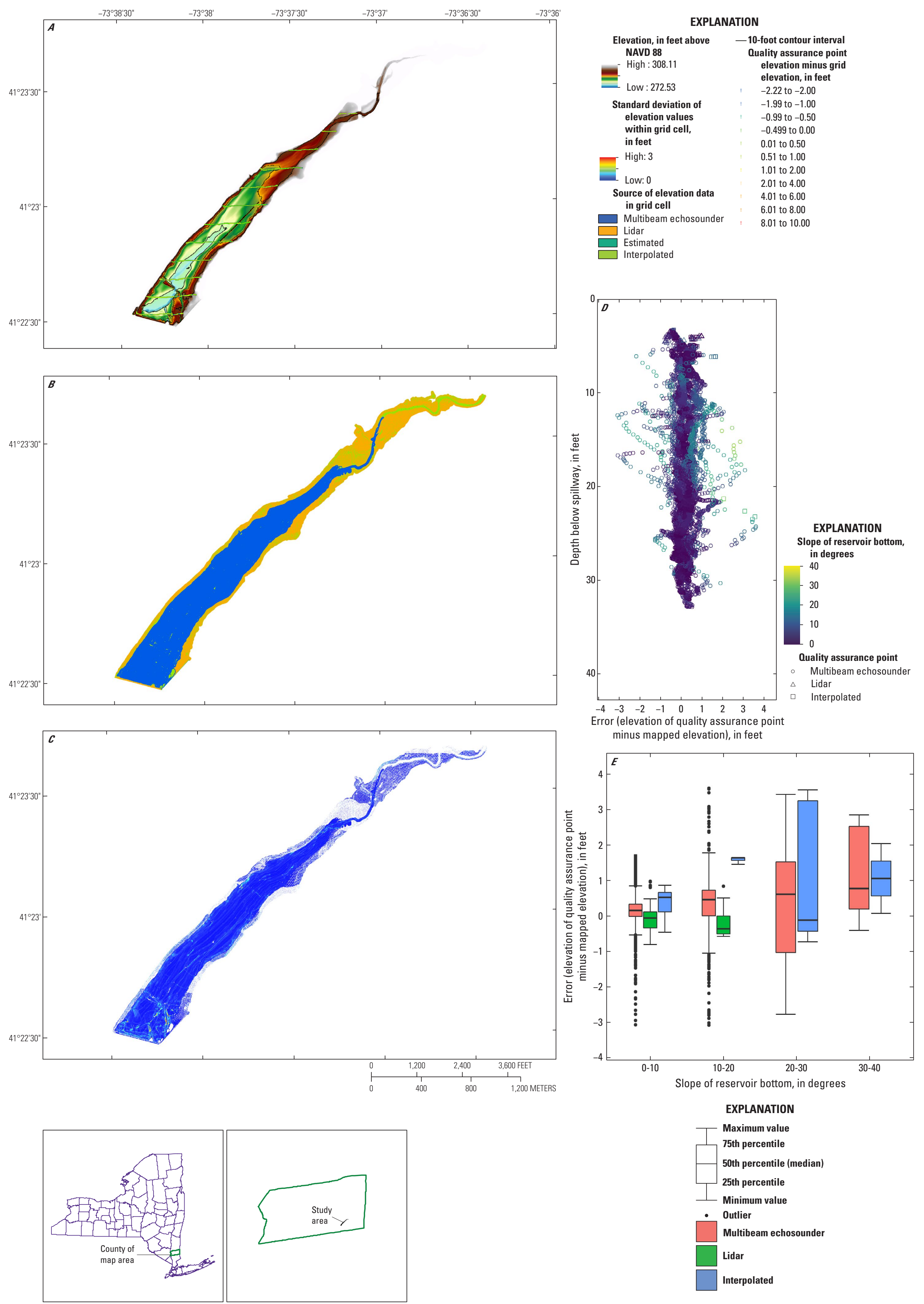

\begin{tabular}{|c|c|}
\hline \multicolumn{2}{|c|}{ EXPLANATION } \\
\hline $\begin{array}{l}\text { Elevation, in feet above } \\
\text { NAVD } 88 \\
- \text { High : } 308.11 \\
\end{array}$ & $\begin{array}{l}\text {-10-foot contour interval } \\
\text { Quality assurance point } \\
\text { elevation minus grid } \\
\text { elevation, in feet }\end{array}$ \\
\hline Low : 272.53 & $\quad-2.22$ to -2.00 \\
\hline $\begin{array}{l}\text { Standard deviation of } \\
\text { elevation values } \\
\text { within grid cell, } \\
\text { in feet }\end{array}$ & $\begin{array}{l}-1.99 \text { to }-1.00 \\
-0.99 \text { to }-0.50 \\
-0.499 \text { to } 0.00 \\
0.01 \text { to } 0.50\end{array}$ \\
\hline High: 3 & 0.51 to 1.00 \\
\hline Low: 0 & 1.01 to 2.00 \\
\hline Source of elevation data & 2.01 to 4.00 \\
\hline $\begin{array}{l}\text { Source of elevation data } \\
\text { in grid cell }\end{array}$ & 4.01 to 6.00 \\
\hline $\begin{array}{l}\text { Multibeam echosounder } \\
\text { Lidar } \\
\text { Estimated } \\
\text { Interpolated }\end{array}$ & $\begin{array}{l}6.01 \text { to } 8.00 \\
8.01 \text { to } 10.00\end{array}$ \\
\hline
\end{tabular}

EXPLANATION

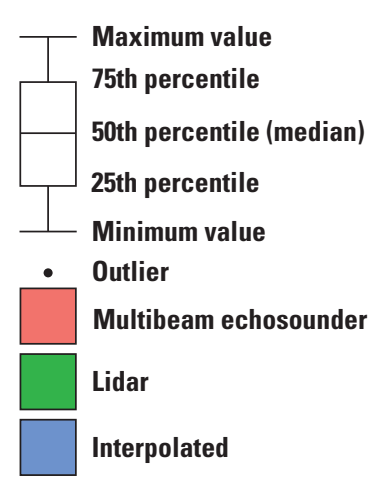

Figure 15. Results of bathymetric mapping of Diverting Reservoir in Putnam County, New York, including maps of $A$, bathymetric elevations, contours, and quality assurance points, $B$, source data type, and $C$, cell standard deviation; and plots showing comparison of quality assurance points and mapped elevation $D$, by depth and slope and $E$, by grid cell data source. Mapped data are from Nystrom and others (2021). Lidar, light detection and ranging; NAVD 88; North American Vertical Datum of 1988. A large version of this figure is available for download at https://doi.org/10.3133/sir20215057. 

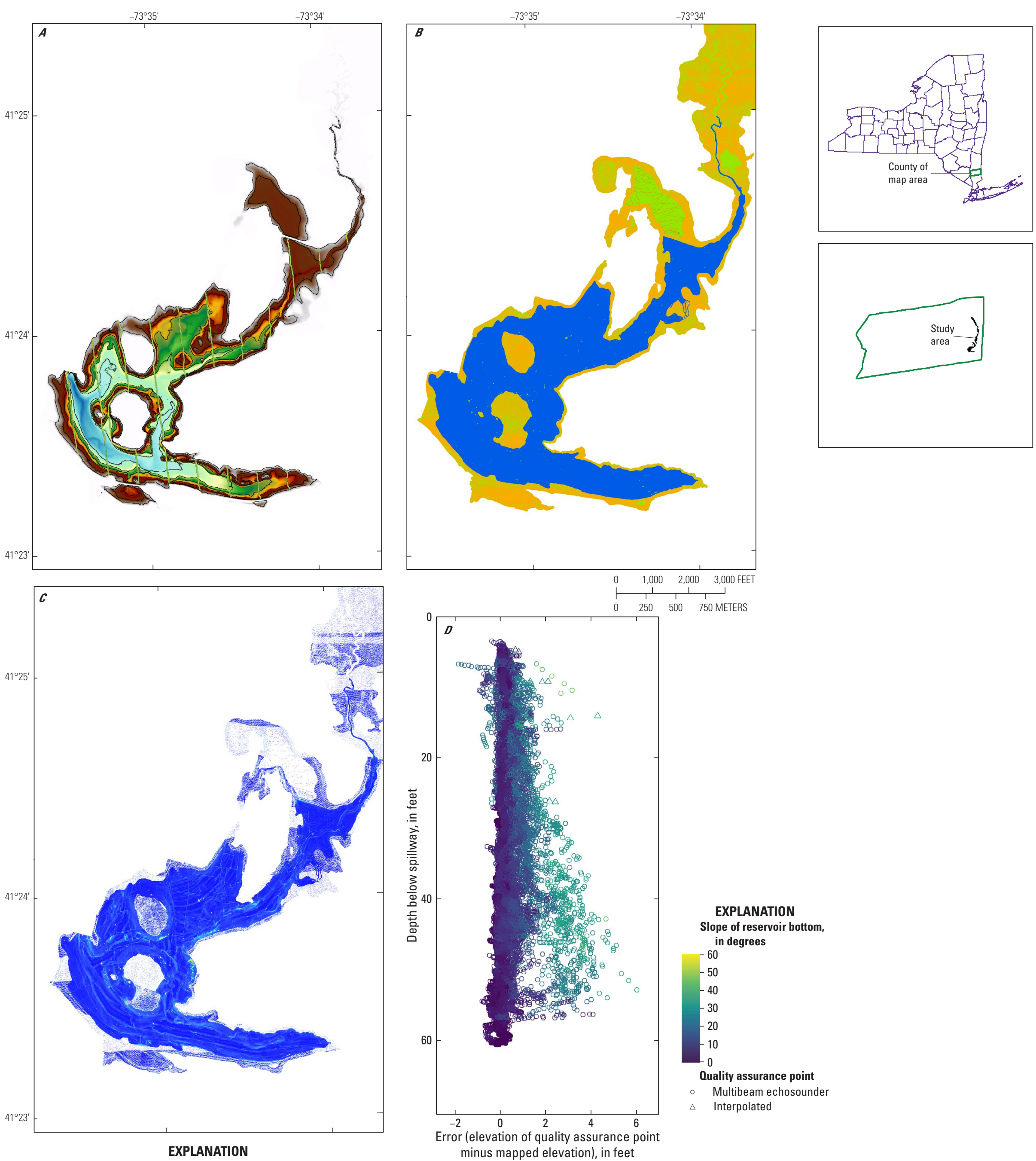

\begin{tabular}{c|c}
$\begin{array}{c}\text { Elevation, in feet above } \\
\text { NAVD } 88\end{array}$ & $\begin{array}{c}\text { 10-foot contour interval } \\
\text { Quality assurance point } \\
\text { elevation minus grid } \\
\text { elevation, in feet }\end{array}$ \\
\hline High : 415.54 & -3.00 to -2.00 \\
Low : 350.37 & -1.99 to -1.00 \\
Standard deviation of \\
elevation values \\
within grid cell, \\
in feet & -0.99 to -0.50 \\
High: 3 & -0.499 to 0.00 \\
Low: 0 & 0.01 to 0.50 \\
Source of elevation data & 0.51 to 1.00 \\
in grid cell & 1.01 to 2.00 \\
\hline Multibeam echosounder & 2.01 to 4.00 \\
\hline Lidar & 4.01 to 6.00 \\
\hline Estimated & 6.01 to 8.00 \\
Interpolated & 8.01 to 12.28 \\
\hline
\end{tabular}

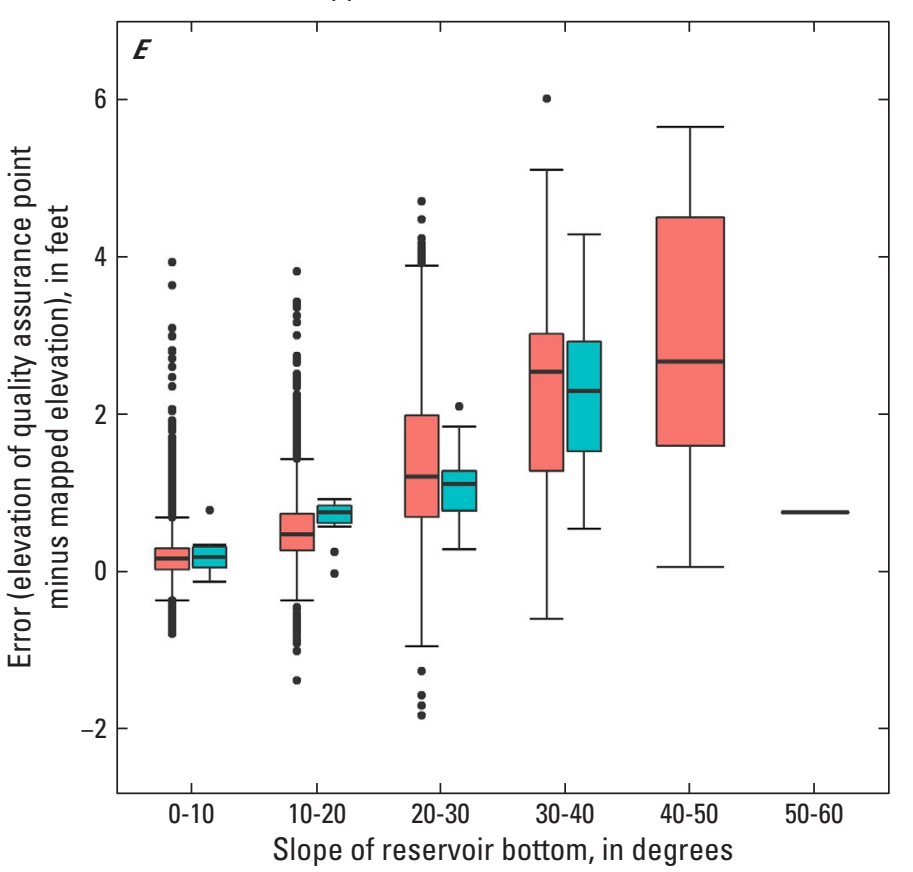

EXPLANATION

T Maximum value

75 th percentile

50th percentile (median)

25th percentile

Linimum value

- Outlier

Multibeam echosounder

Interpolated

Figure 16. Results of bathymetric mapping of East Branch Reservoir in Putnam County, New York, including maps of $A$, bathymetric elevations, contours, and quality assurance points, $B$, source data type, and $C$, cell standard deviation; and plots showing comparison of quality assurance points and mapped elevation $D$, by depth and slope and $E$, by grid cell data source. Mapped data are from Nystrom and others (2021). Lidar, light detection and ranging; NAVD 88; North American Vertical Datum of 1988. A large version of this figure is available for download at https://doi.org/10.3133/sir20215057. 

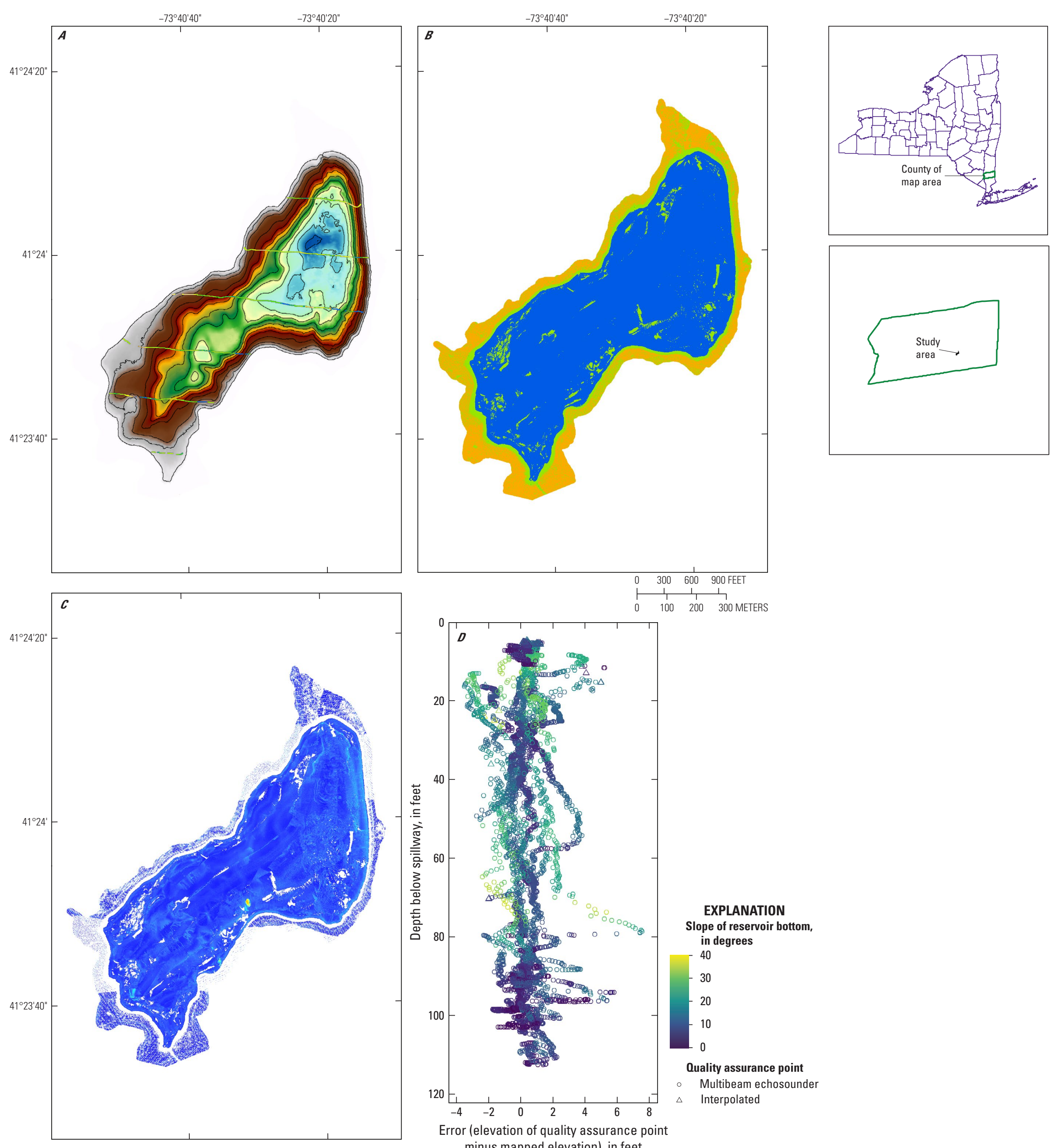

EXPLANATION

minus mapped elevation), in feet

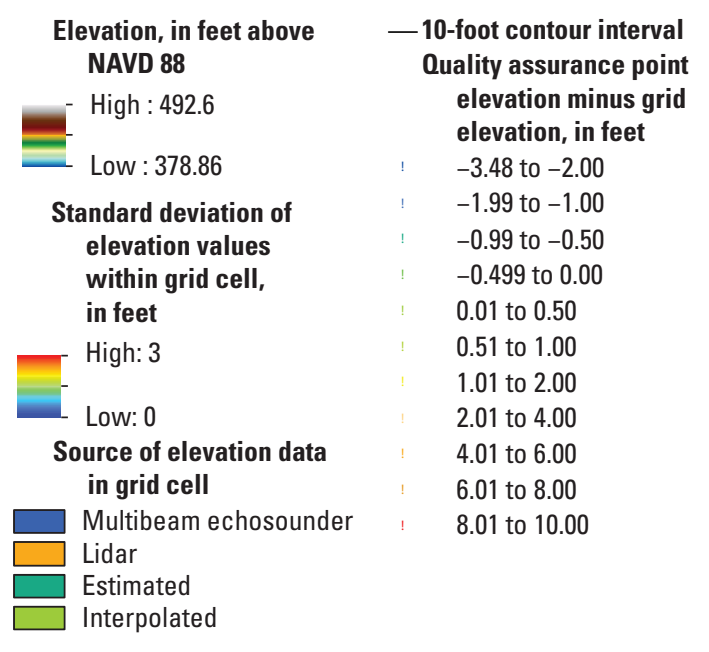

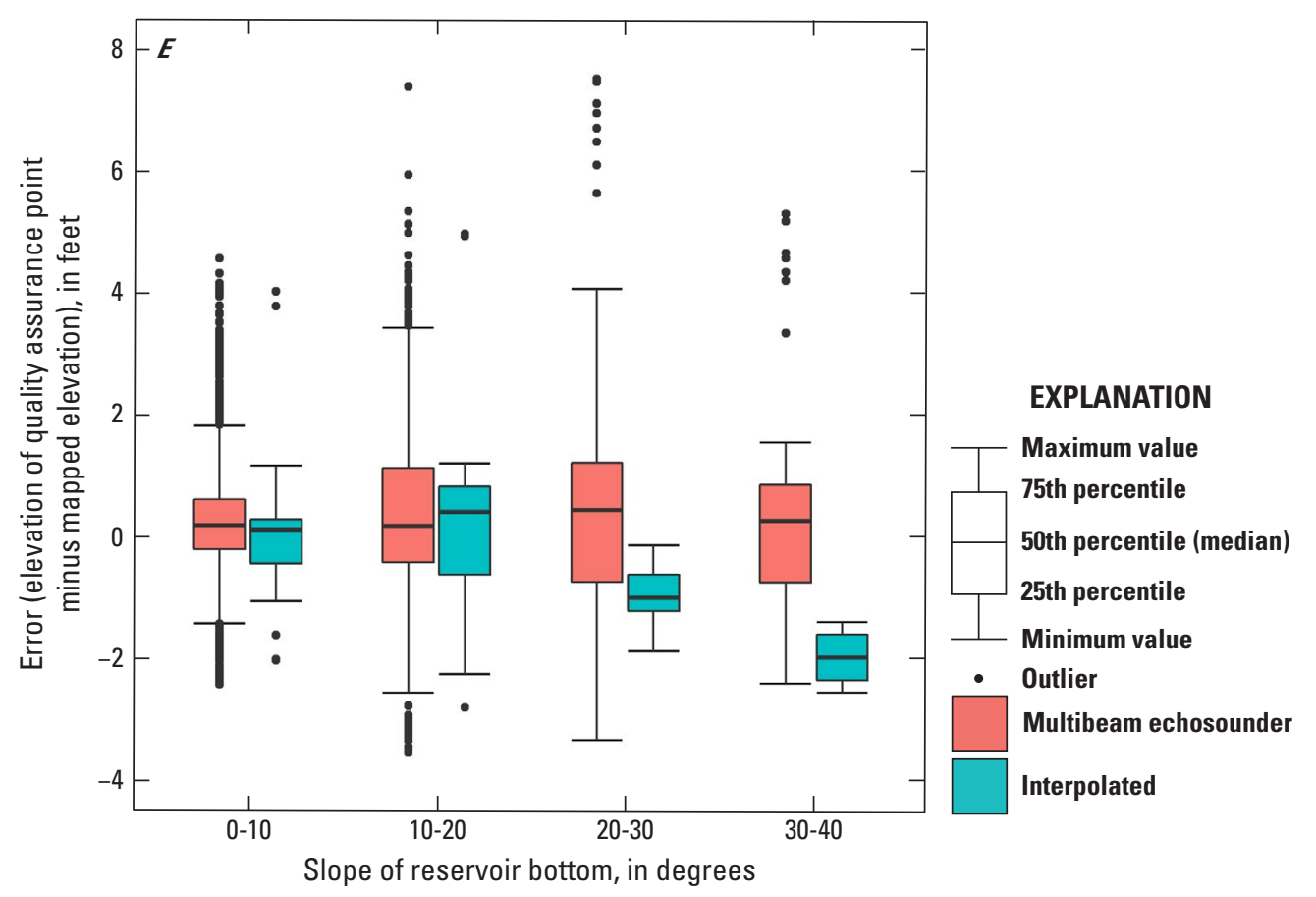

Figure 17. Results of bathymetric mapping of Lake Gilead in Putnam County, New York, including maps of $A$, bathymetric elevations, contours, and quality assurance points, $B$, source data type, and $C$, cell standard deviation; and plots showing comparison of quality assurance points and mapped elevation $D$, by depth and slope and $E$, by grid cell data source. Mapped data are from Nystrom and others (2021). Lidar, light detection and ranging; NAVD 88; North American Vertical Datum of 1988. A large version of this figure is available for download at https://doi.org/10.3133/sir20215057. 

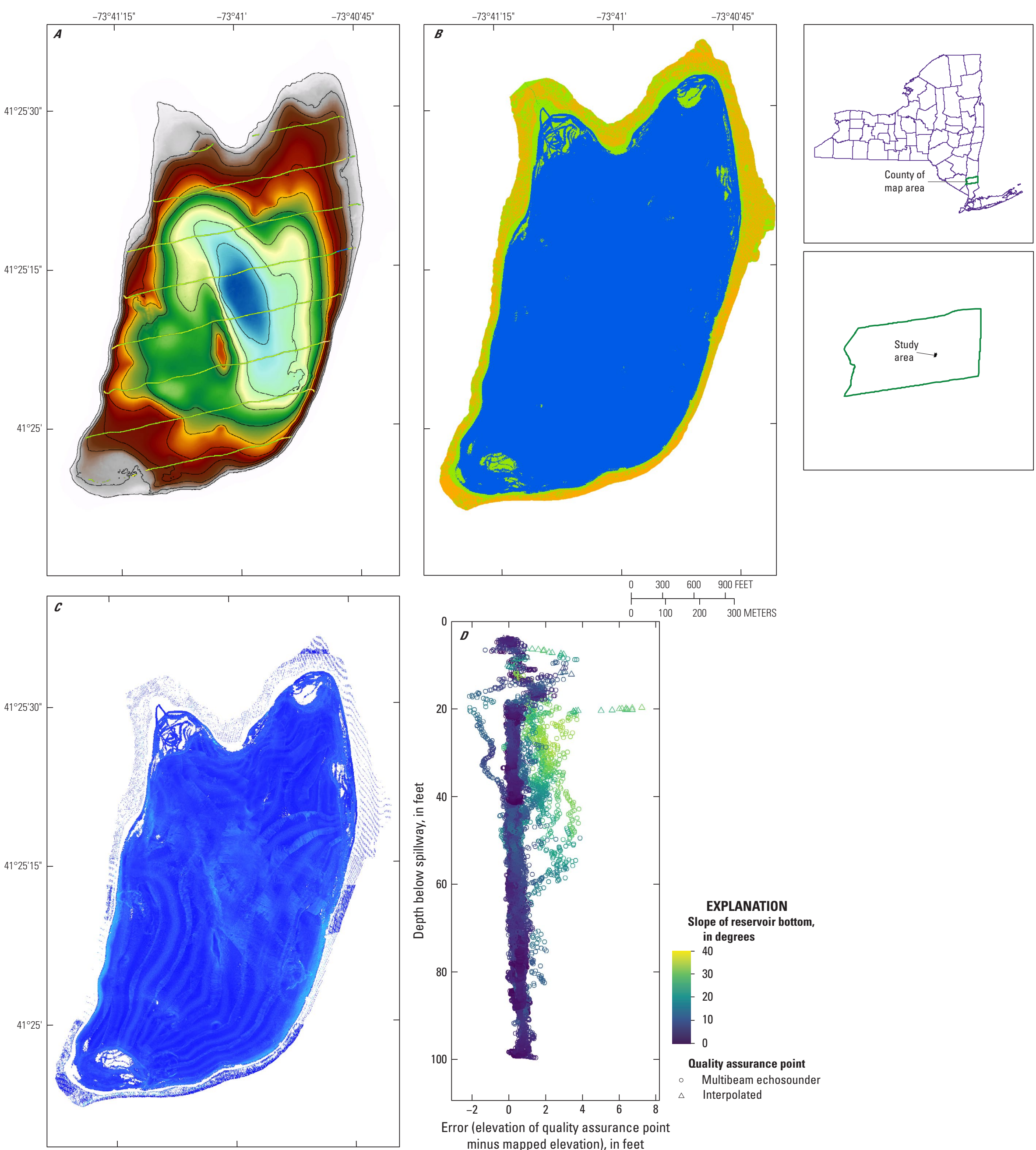

Error (elevation of quality assurance poin minus mapped elevation), in feet

\begin{tabular}{|c|c|}
\hline $\begin{array}{l}\text { Elevation, in feet above } \\
\text { NAVD } 88 \\
- \text { High : } 501 \\
\end{array}$ & $\begin{array}{l}\text {-10-foot contour interval } \\
\text { Quality assurance point } \\
\text { elevation minus grid } \\
\text { elevation, in feet }\end{array}$ \\
\hline Low : 400.43 & -2.13 to -2.00 \\
\hline $\begin{array}{l}\text { Standard deviation of } \\
\text { elevation values } \\
\text { within grid cell, } \\
\text { in feet }\end{array}$ & $\begin{array}{l}-1.99 \text { to }-1.00 \\
-0.99 \text { to }-0.50 \\
-0.499 \text { to } 0.00 \\
0.01 \text { to } 0.50\end{array}$ \\
\hline High: 3 & $\begin{array}{l}0.51 \text { to } 1.00 \\
1.01 \text { to } 2.00\end{array}$ \\
\hline Low: 0 & 2.01 to 4.00 \\
\hline $\begin{array}{l}\text { Source of elevation data } \\
\text { in grid cell }\end{array}$ & $\begin{array}{l}4.01 \text { to } 6.00 \\
6.01 \text { to } 8.00\end{array}$ \\
\hline $\begin{array}{l}\text { Multibeam echosounder } \\
\text { Lidar } \\
\text { Estimated } \\
\text { Interpolated }\end{array}$ & 8.01 to 10.00 \\
\hline
\end{tabular}

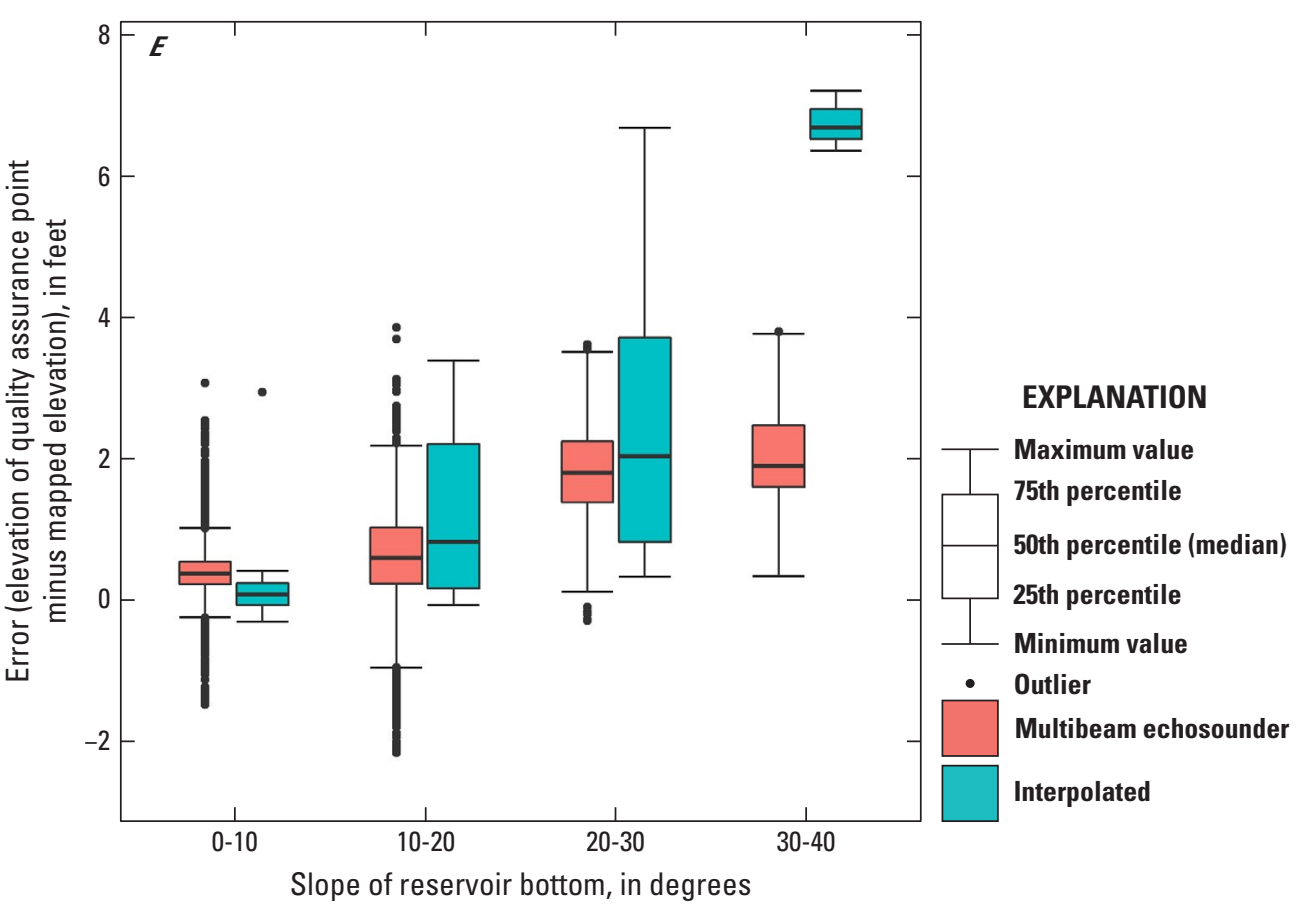

Figure 18. Results of bathymetric mapping of Lake Gleneida in Putnam County, New York, including maps of $A$, bathymetric elevations, contours, and quality assurance points, $B$, source data type, and $C$, cell standard deviation; and plots showing comparison of quality assurance points and mapped elevation $D$, by depth and slope and $E$, by grid cell data source. Mapped data are from Nystrom and others (2021). Lidar, light detection and ranging; NAVD 88; North American Vertical Datum of 1988. A large version of this figure is available for download at https://doi.org/10.3133/sir20215057. 

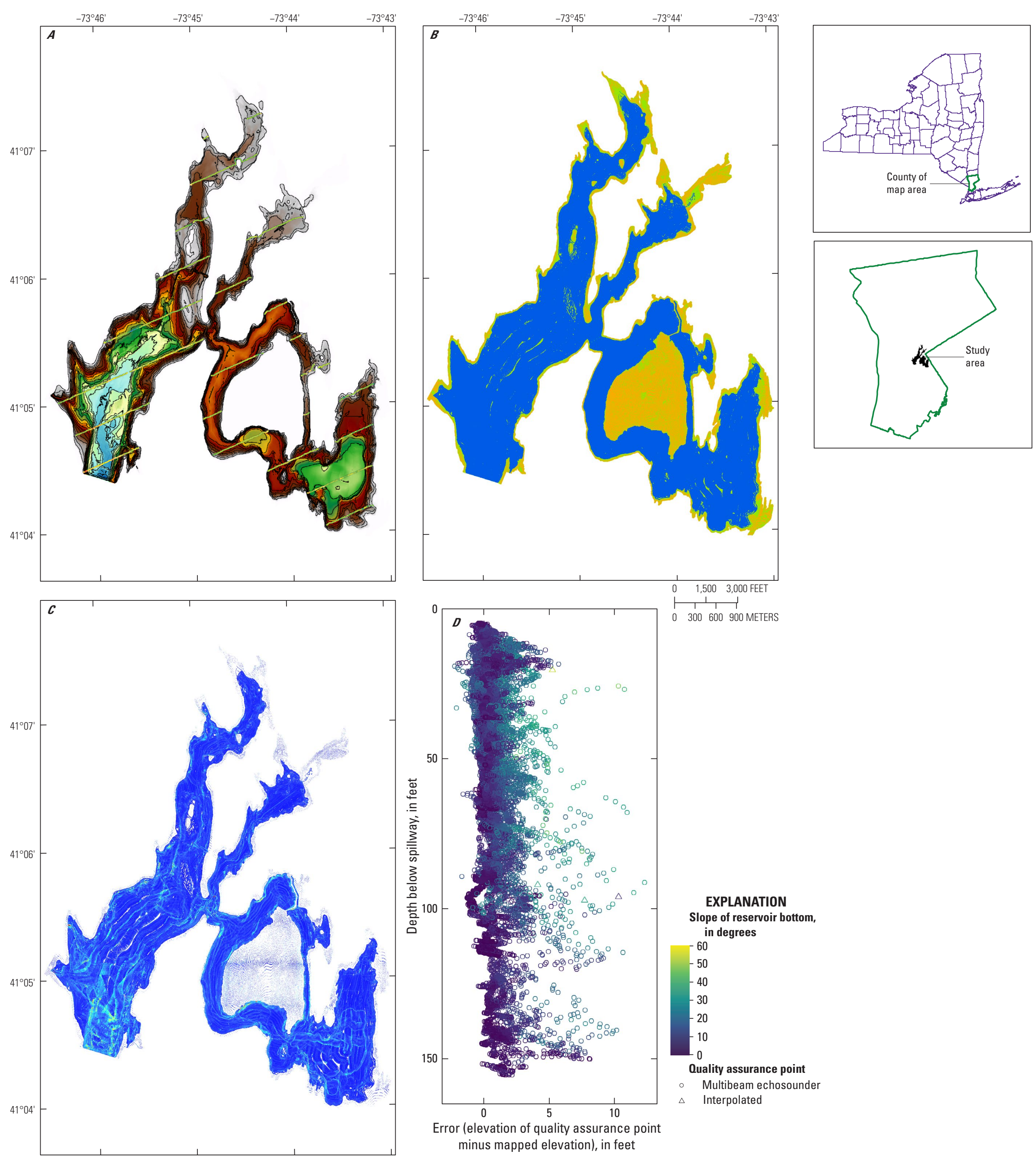

\begin{tabular}{|cc|}
\multicolumn{2}{c|}{ EXPLANATION } \\
$\begin{array}{c}\text { Elevation, in feet above } \\
\text { NAVD } 88\end{array}$ & $\begin{array}{c}\text { 10-foot contour interval } \\
\text { Quality assurance point } \\
\text { elevation minus grid } \\
\text { elevation, in feet }\end{array}$ \\
\hline High : 355.98 & -2.22 to -2.00 \\
\hline Low : 194.3 & -1.99 to -1.00 \\
Standard deviation of & -0.99 to -0.50 \\
elevation values & -0.499 to 0.00 \\
within grid cell, & 0.01 to 0.50 \\
in feet & 0.51 to 1.00 \\
\hline High: 3 & 1.01 to 2.00 \\
\hline Low: 0 & 2.01 to 4.00 \\
Source of elevation data & 4.01 to 6.00 \\
in grid cell & 6.01 to 8.00 \\
\hline Multibeam echosounder & 8.01 to 12.28 \\
\hline Lidar & \\
\hline Estimated & \\
\hline Interpolated & \\
\hline
\end{tabular}

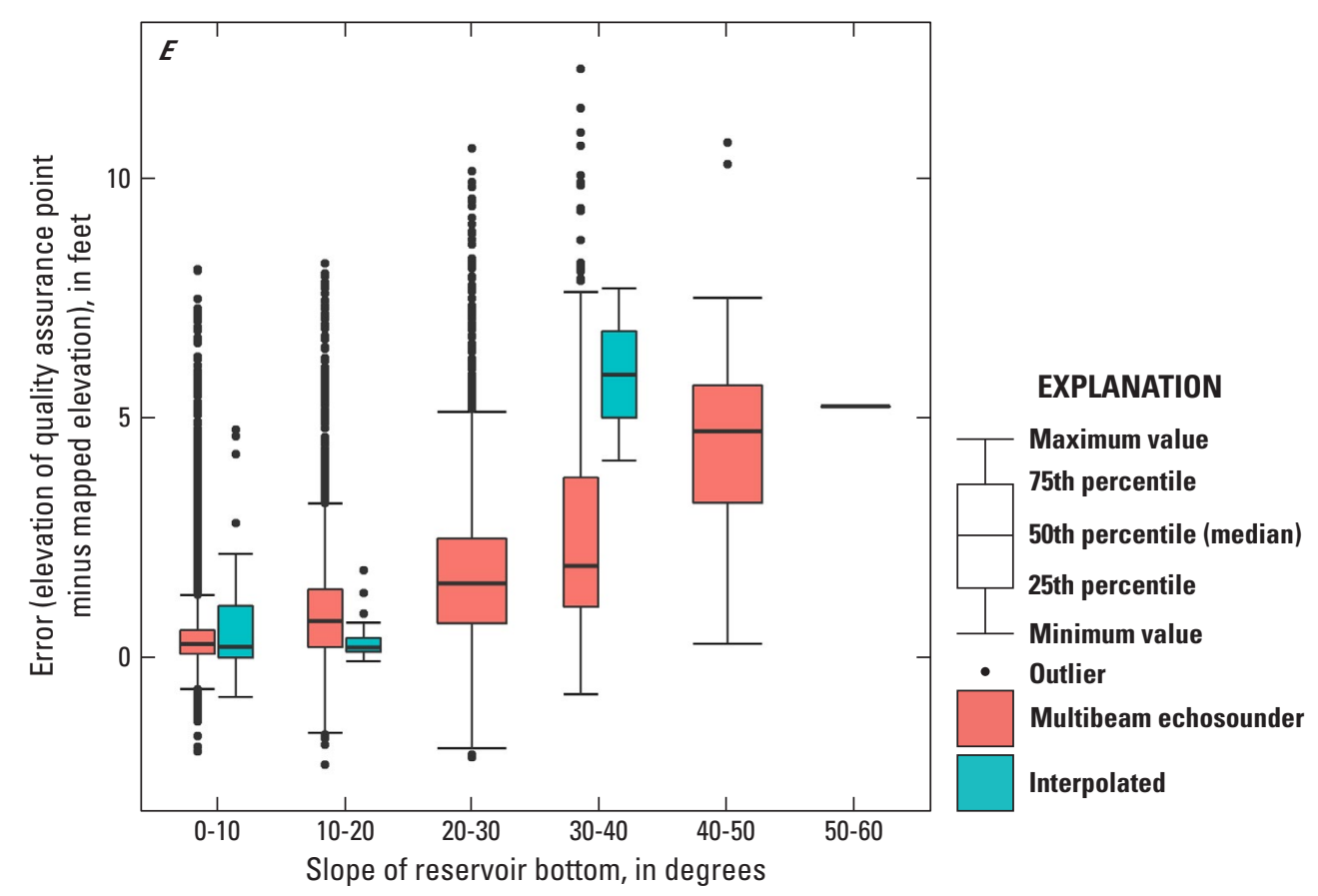

Figure 19. Results of bathymetric mapping of Kensico Reservoir in Westchester County, New York, including maps of $A$, bathymetric elevations, contours, and quality assurance points, $B$, source data type, and $C$, cell standard deviation; and plots showing comparison of quality assurance points and mapped elevation $D$, by depth and slope and $E$, by grid cell data source. Mapped data are from Nystrom and others (2021). Lidar, light detection and ranging; NAVD 88; North American Vertical Datum of 1988. A large version of this figure is available for download at https://doi.org/10.3133/sir20215057. 

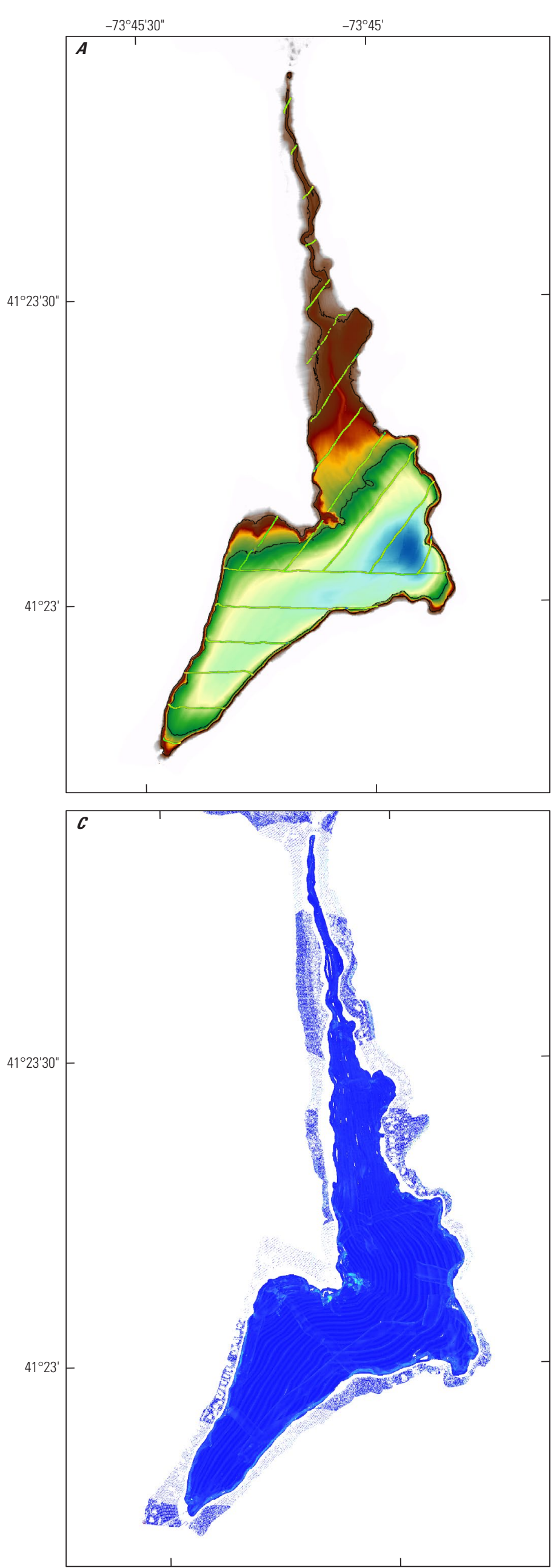

EXPLANATION

\begin{tabular}{|c|c|}
$\begin{array}{c}\text { Elevation, in feet above } \\
\text { NAVD 88 }\end{array}$ & $\begin{array}{c}\text { 10-foot contour interval } \\
\text { Quality assurance point } \\
\text { elevation minus grid } \\
\text { elevation, in feet }\end{array}$ \\
\hline High : 585.63 & -3.00 to -2.00 \\
\hline Low : 560.04 & -1.99 to -1.00 \\
Standard deviation of & -0.99 to -0.50 \\
elevation values & -0.499 to 0.00 \\
within grid cell, & 0.01 to 0.50 \\
in feet & 0.51 to 1.00 \\
\hline High: 3 & 1.01 to 2.00 \\
\hline Low: 0 & 2.01 to 4.00 \\
Source of elevation data & 4.01 to 6.00 \\
in grid cell & 6.01 to 8.00 \\
\hline Multibeam echosounder & 8.01 to 10.00 \\
\hline Lidar & \\
\hline Estimated & \\
\hline Interpolated & \\
\hline
\end{tabular}
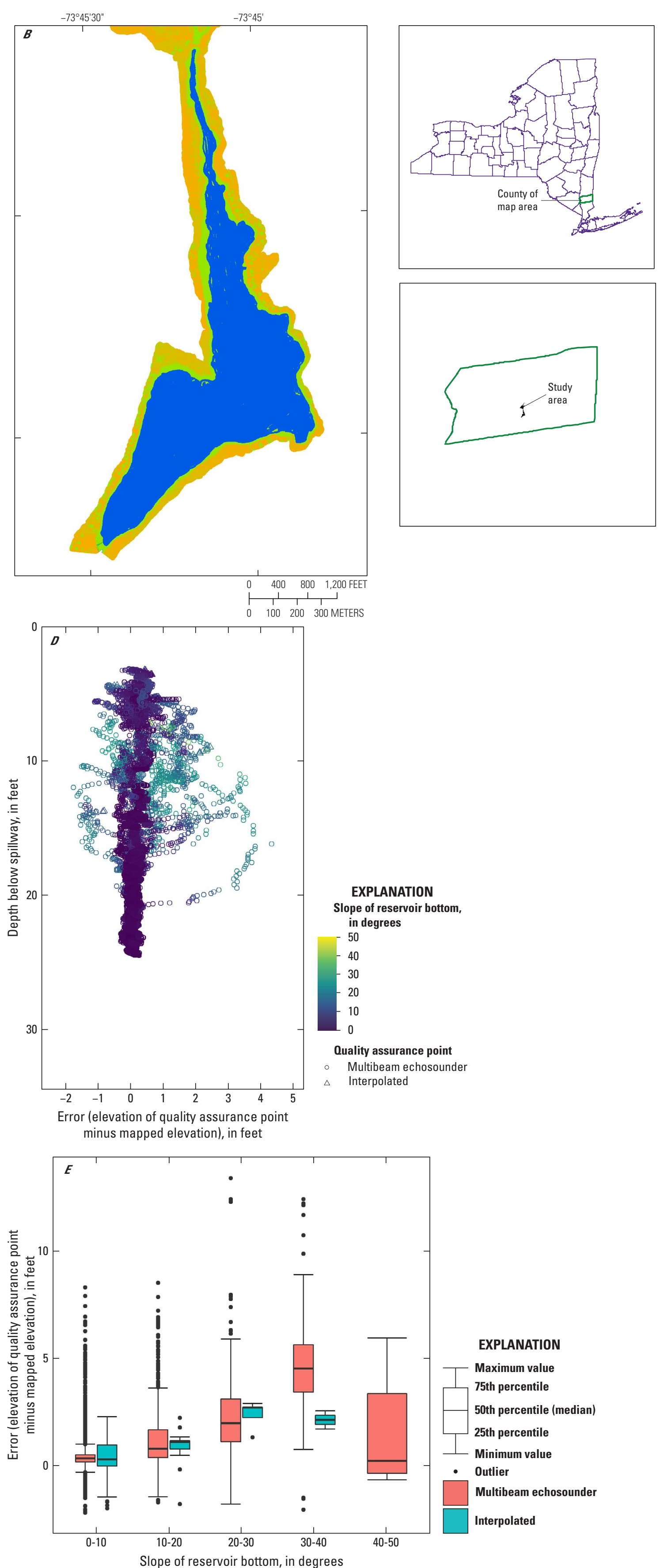

Figure 20. Results of bathymetric mapping of Kirk Lake in Putnam County, New York, including maps of $A$, bathymetric elevations, contours, and quality assurance points, $B$, source data type, and $C$, cell standard deviation; and plots showing comparison of quality assurance points and mapped elevation $D$, by depth and slope and $E$, by grid cell data source. Mapped data are from Nystrom and others (2021). Lidar, light detection and ranging; NAVD 88; North American Vertical Datum of 1988. A large version of this figure is available for download at https://doi.org/10.3133/sir20215057. 

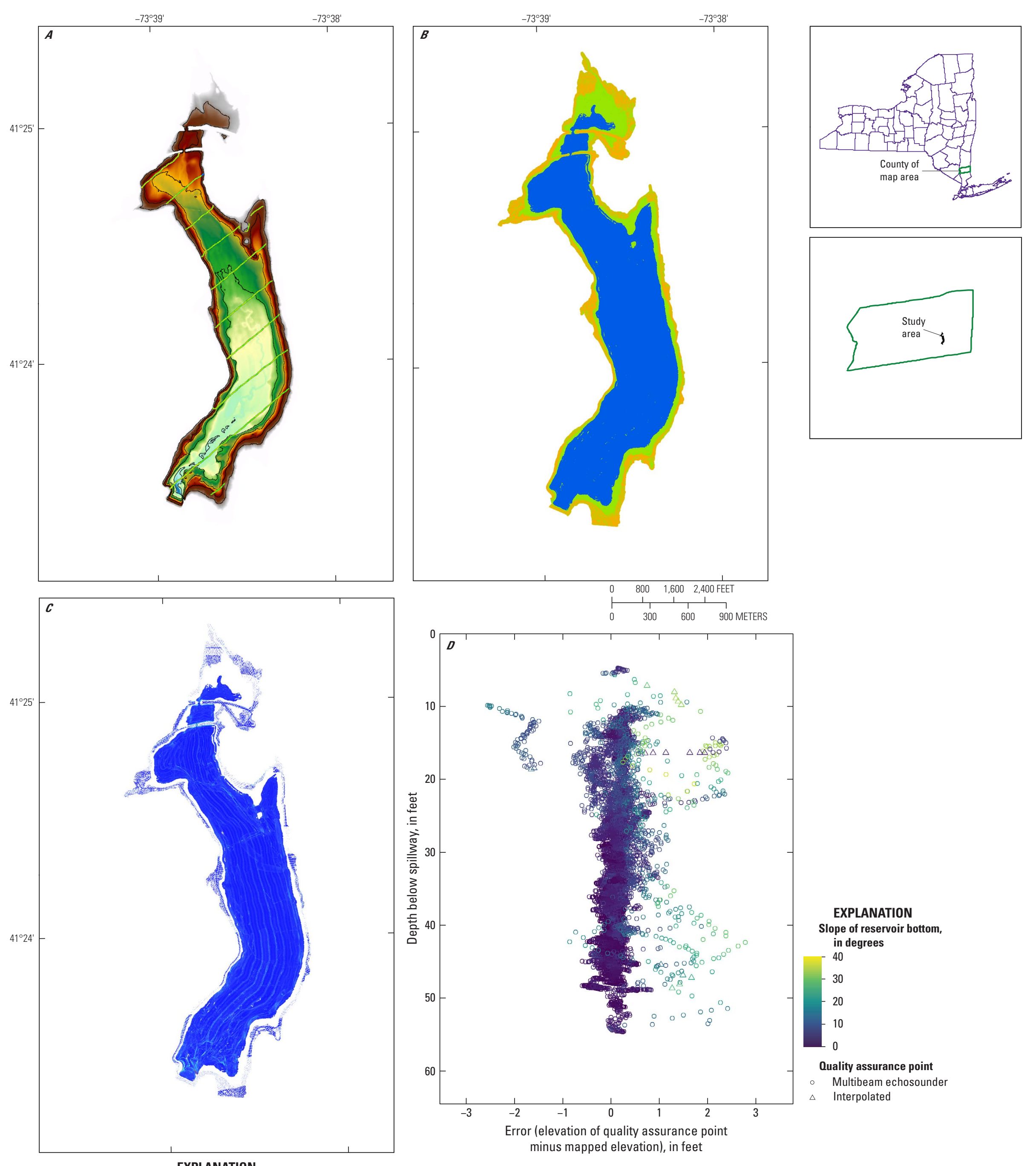

\section{EXPLANATION}

Slope of reservoir bottom,

in degrees

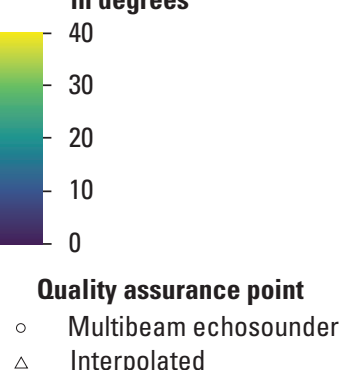

EXPLANATION

\begin{tabular}{|c|c|}
$\begin{array}{c}\text { Elevation, in feet above } \\
\text { NAVD } 88\end{array}$ & $\begin{array}{c}\text { 10-foot contour interval } \\
\text { Quality assurance point } \\
\text { elevation minus grid } \\
\text { elevation, in feet }\end{array}$ \\
\hline High : 368.7 & -3.00 to -2.00 \\
\hline Low : 311.09 & -1.99 to -1.00 \\
Standard deviation of & -0.99 to -0.50 \\
elevation values & -0.499 to 0.00 \\
within grid cell, & 0.01 to 0.50 \\
in feet & 0.51 to 1.00 \\
\hline High: 3 & 1.01 to 2.00 \\
\hline Low: 0 & 2.01 to 4.00 \\
Source of elevation data & 4.01 to 6.00 \\
in grid cell & 6.01 to 8.00 \\
\hline Multibeam echosounder & 8.01 to 10.00 \\
\hline Lidar & \\
\hline Estimated & \\
\hline Interpolated & \\
\hline
\end{tabular}

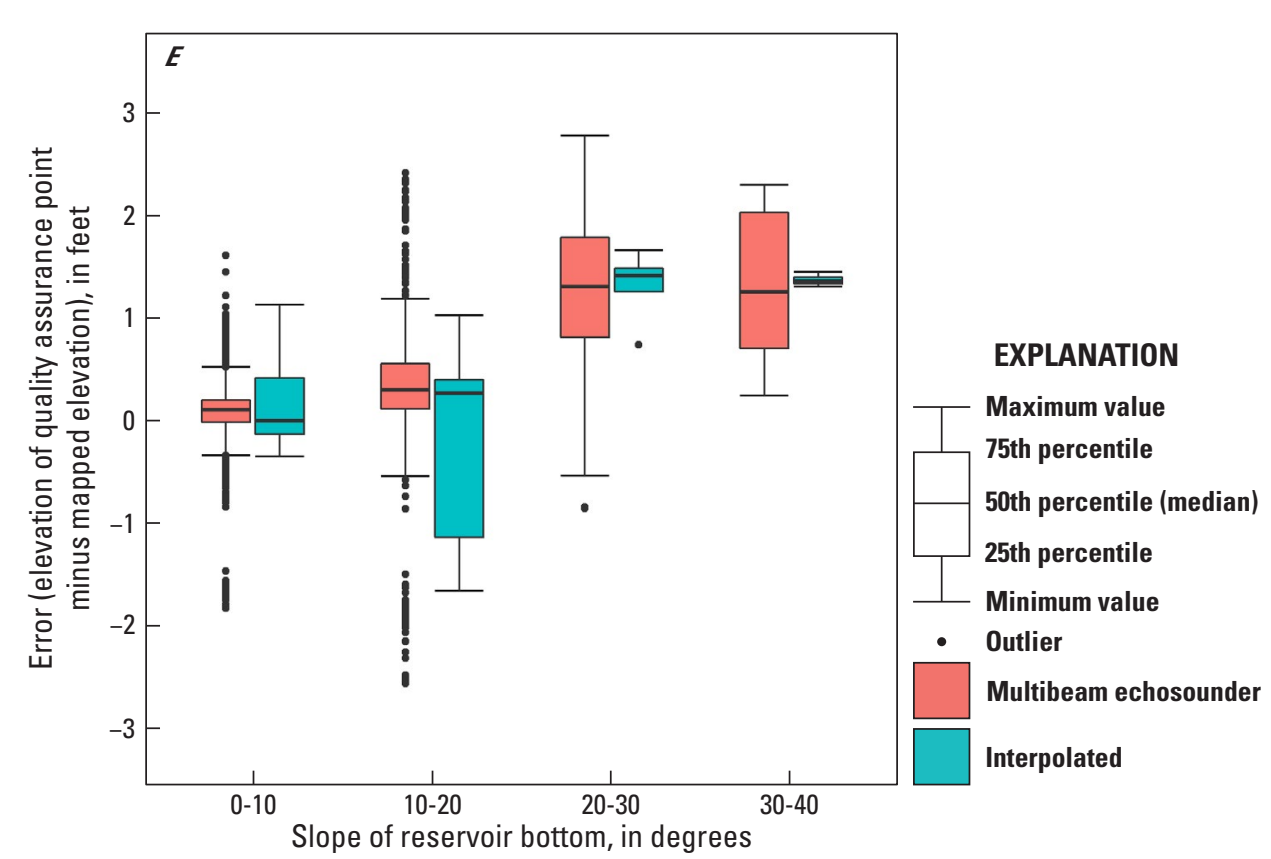

Figure 21. Results of bathymetric mapping of Middle Branch Reservoir in Putnam County, New York, including maps of $A$, bathymetric elevations, contours, and quality assurance points, $B$, source data type, and $C$, cell standard deviation; and plots showing comparison of quality assurance points and mapped elevation $D$, by depth and slope and $E$, by grid cell data source. Mapped data are from Nystrom and others (2021). Lidar, light detection and ranging; NAVD 88; North American Vertical Datum of 1988. A large version of this figure is available for download at https://doi.org/10.3133/sir20215057. 

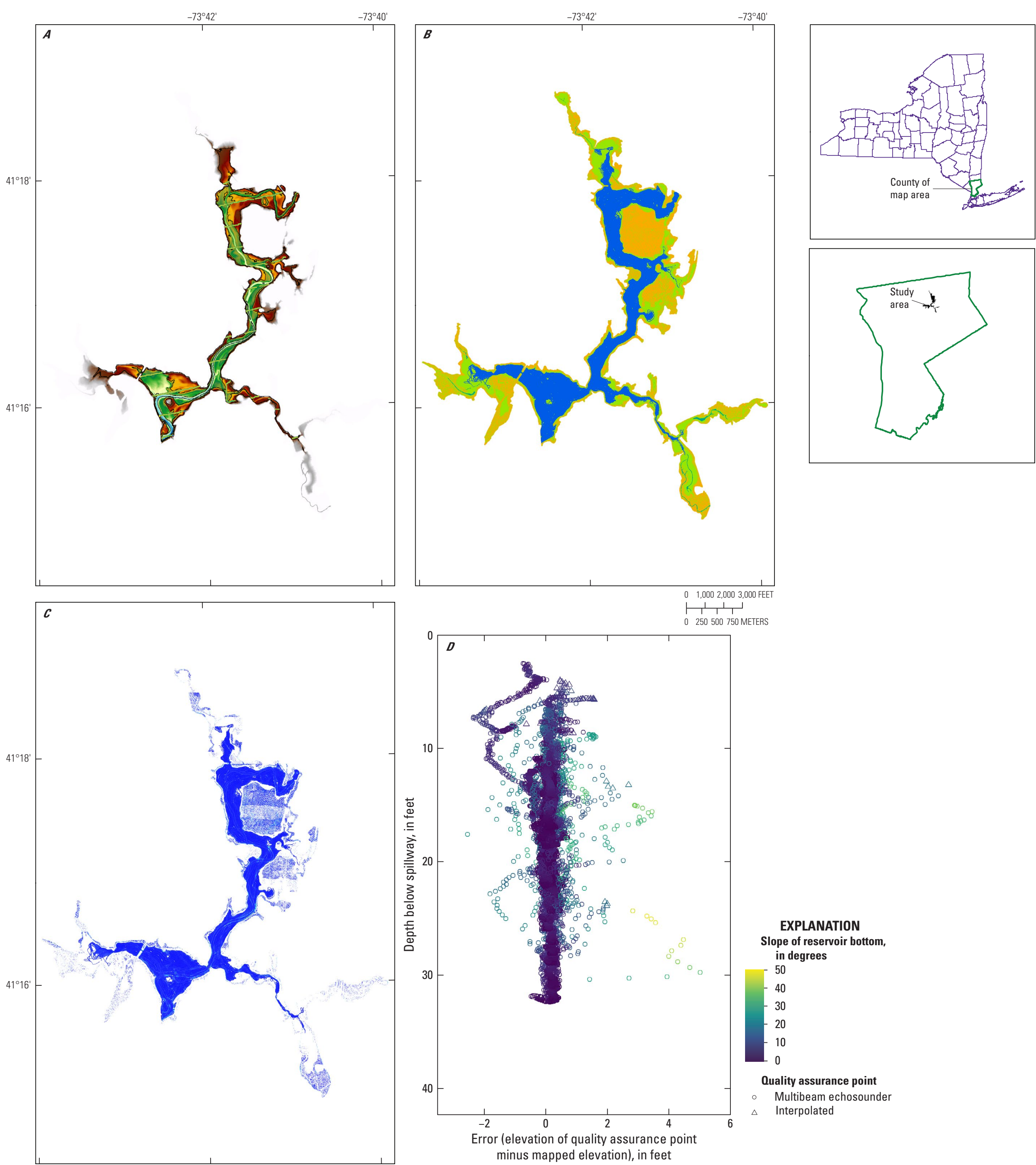

EXPLANATION

\begin{tabular}{|c|c|}
\hline $\begin{array}{l}\text { Elevation, in feet above } \\
\text { NAVD } 88 \\
\text { - High : } 198.02 \\
\end{array}$ & $\begin{array}{l}\text {-10-foot contour interval } \\
\text { Quality assurance point } \\
\text { elevation minus grid } \\
\text { elevation, in feet }\end{array}$ \\
\hline Low : 163.38 & -2.53 to -2.20 \\
\hline $\begin{array}{l}\text { Standard deviation of } \\
\text { elevation values } \\
\text { within grid cell, } \\
\text { in feet }\end{array}$ & $\begin{array}{l}-2.21 \text { to }-1.00 \\
-0.99 \text { to }-0.50 \\
-0.499 \text { to } 0.00 \\
0.01 \text { to } 0.50\end{array}$ \\
\hline High: 3 & 0.51 to 1.00 \\
\hline Low: 0 & $\begin{array}{l}1.01 \text { to } 2.00 \\
2.01 \text { to } 4.00\end{array}$ \\
\hline $\begin{array}{l}\text { Source of elevation data } \\
\text { in grid cell }\end{array}$ & 4.01 to 6.00 \\
\hline $\begin{array}{l}\text { Multibeam echosounder } \\
\square \text { Lidar } \\
\text { Estimated } \\
\text { Interpolated }\end{array}$ & $\begin{array}{l}6.01 \text { to } 8.00 \\
8.01 \text { to } 10.00\end{array}$ \\
\hline
\end{tabular}

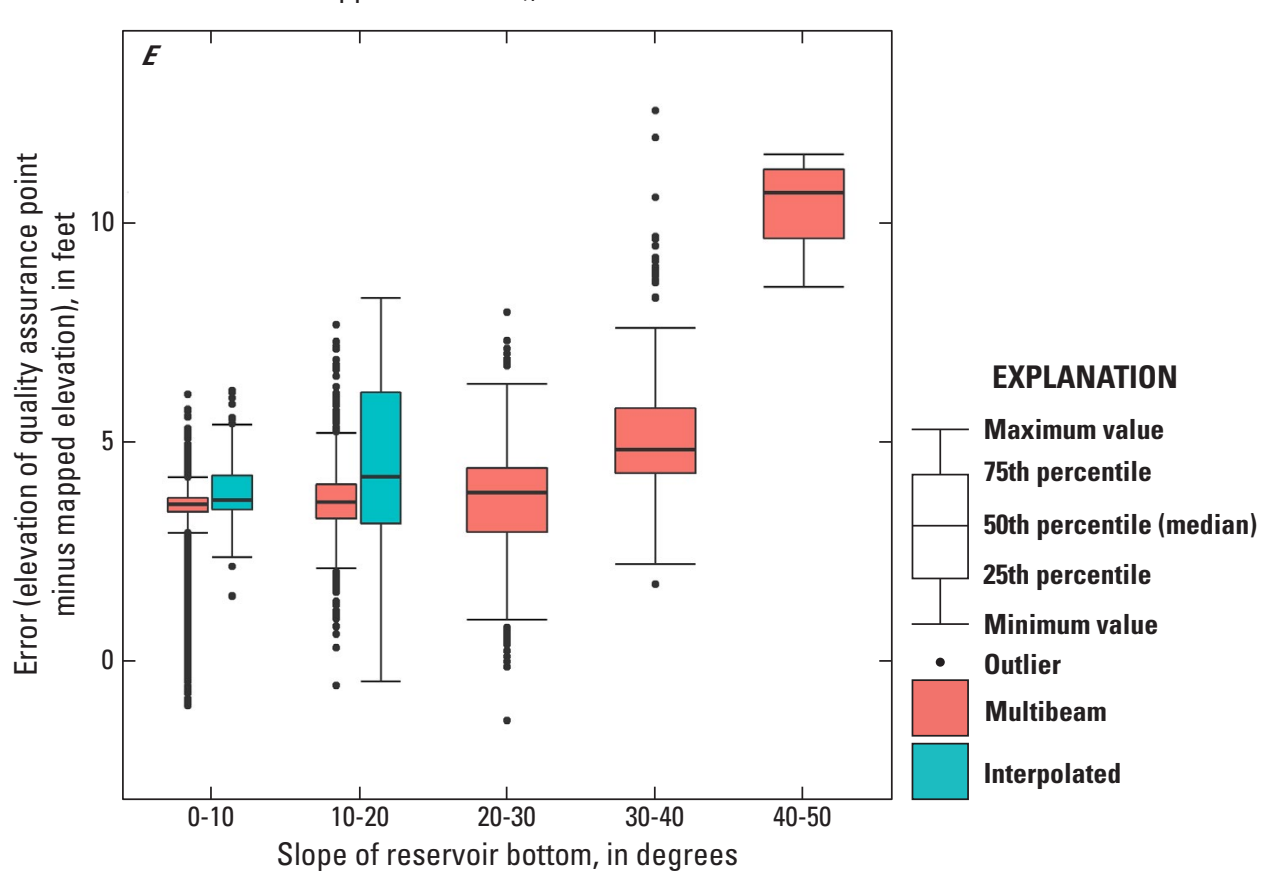

Figure 22. Results of bathymetric mapping of Muscoot Reservoir in Westchester County, New York, including maps of $A$, bathymetric elevations, contours, and quality assurance points, $B$, source data type, and $C$, cell standard deviation; and plots showing comparison of quality assurance points and mapped elevation $D$, by depth and slope and $E$, by grid cell data source. Mapped data are from Nystrom and others (2021). Lidar, light detection and ranging; NAVD 88; North American Vertical Datum of 1988. A large version of this figure is available for download at https://doi.org/10.3133/sir20215057. 


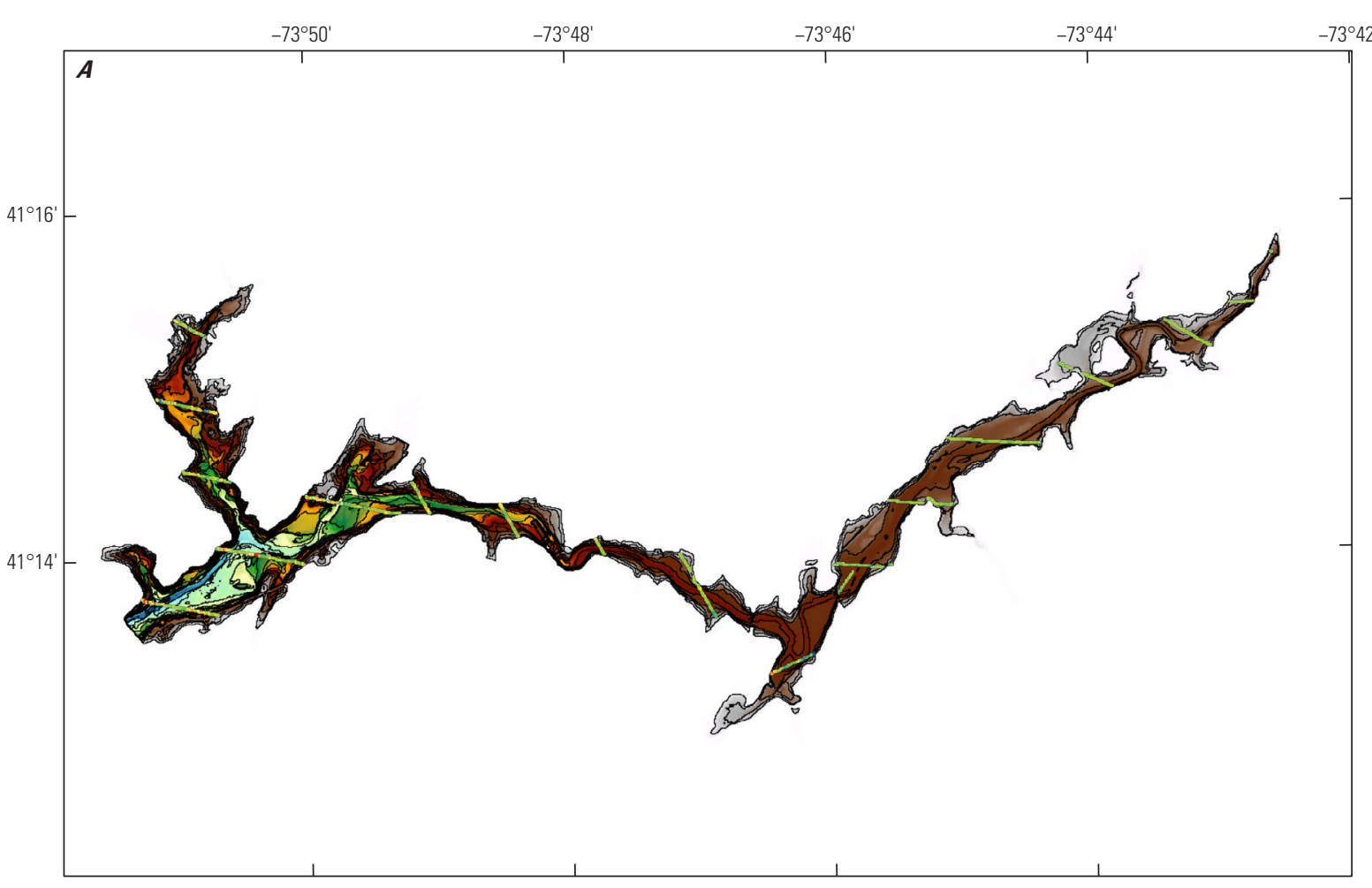

\begin{tabular}{|c|c|}
$\begin{array}{c}\text { EXPLANATION } \\
\text { Elevation, in feet above } \\
\text { NAVD 1988 }\end{array}$ & $\begin{array}{c}\text { 10-foot contour interval } \\
\text { Quality assurance point } \\
\text { elevation minus grid } \\
\text { elevation, in feet }\end{array}$ \\
\hline High : 328.23 & -4.57 to -2.00 \\
\hline Low : 214.06 & -1.99 to -1.00 \\
Standard deviation of & -0.99 to -0.50 \\
elevation values & -0.499 to 0.00 \\
within grid cell, & 0.01 to 0.50 \\
in feet & 0.51 to 1.00 \\
High: 3 & 1.01 to 2.00 \\
\hline Low: 0 & 2.01 to 4.00 \\
Source of elevation data & 4.01 to 6.00 \\
in grid cell & 6.01 to 8.00 \\
\hline Multibeam echosounder & 8.01 to 17.59 \\
\hline Lidar & \\
\hline Estimated & \\
\hline Interpolated &
\end{tabular}
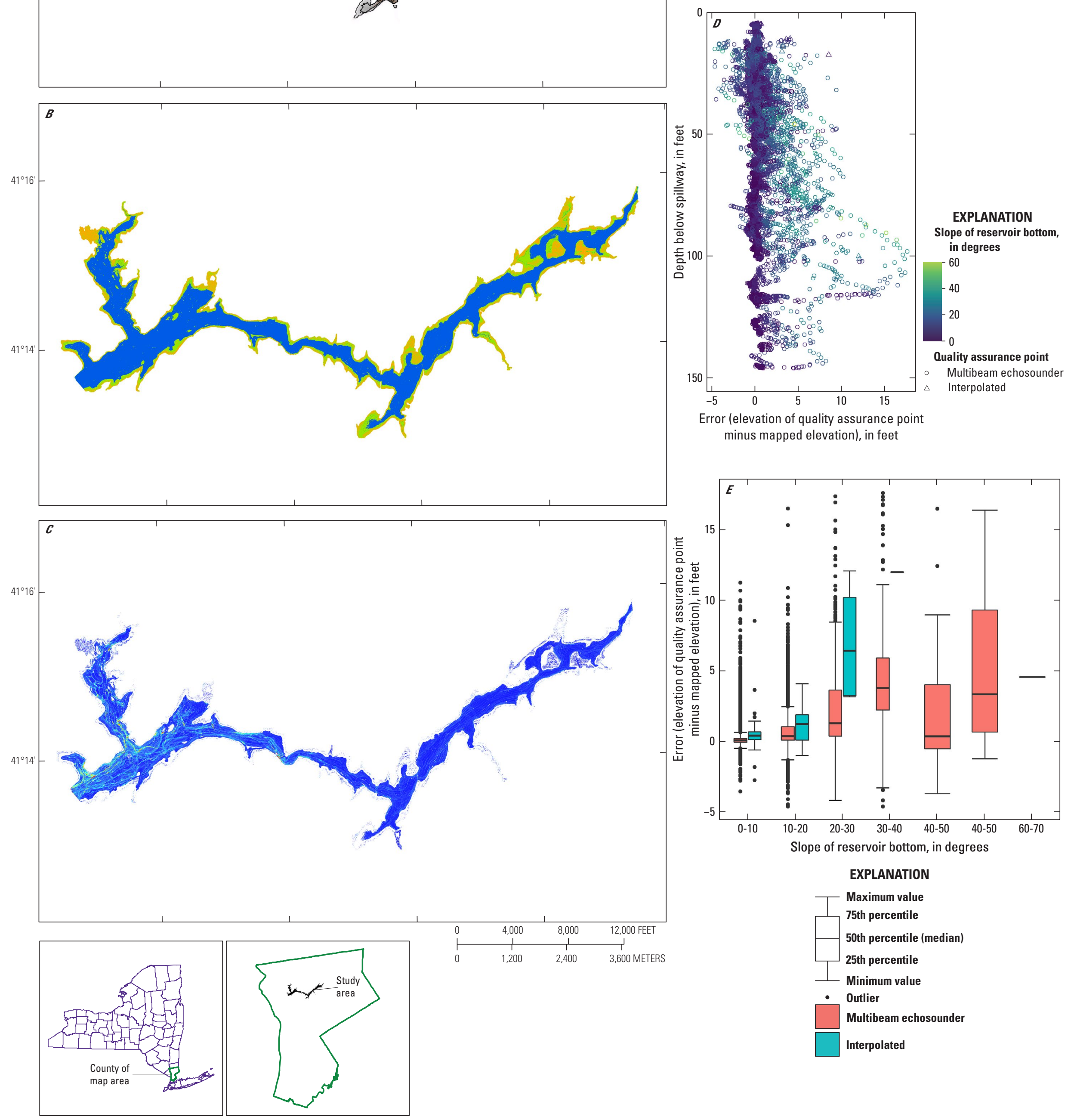

Figure 23. Results of bathymetric mapping of New Croton Reservoir in Westchester County, New York, including maps of $A$, bathymetric elevations, contours, and quality assurance points, $B$, source data type, and $C$, cell standard deviation; and plots showing comparison of quality assurance points and mapped elevation $D$, by depth and slope and $E$, by grid cell data source. Mapped data are from Nystrom and others (2021). Lidar, light detection and ranging; NAVD 88; North American Vertical Datum of 1988. A large version of this figure is available for download at https://doi.org/10.3133/sir20215057. 

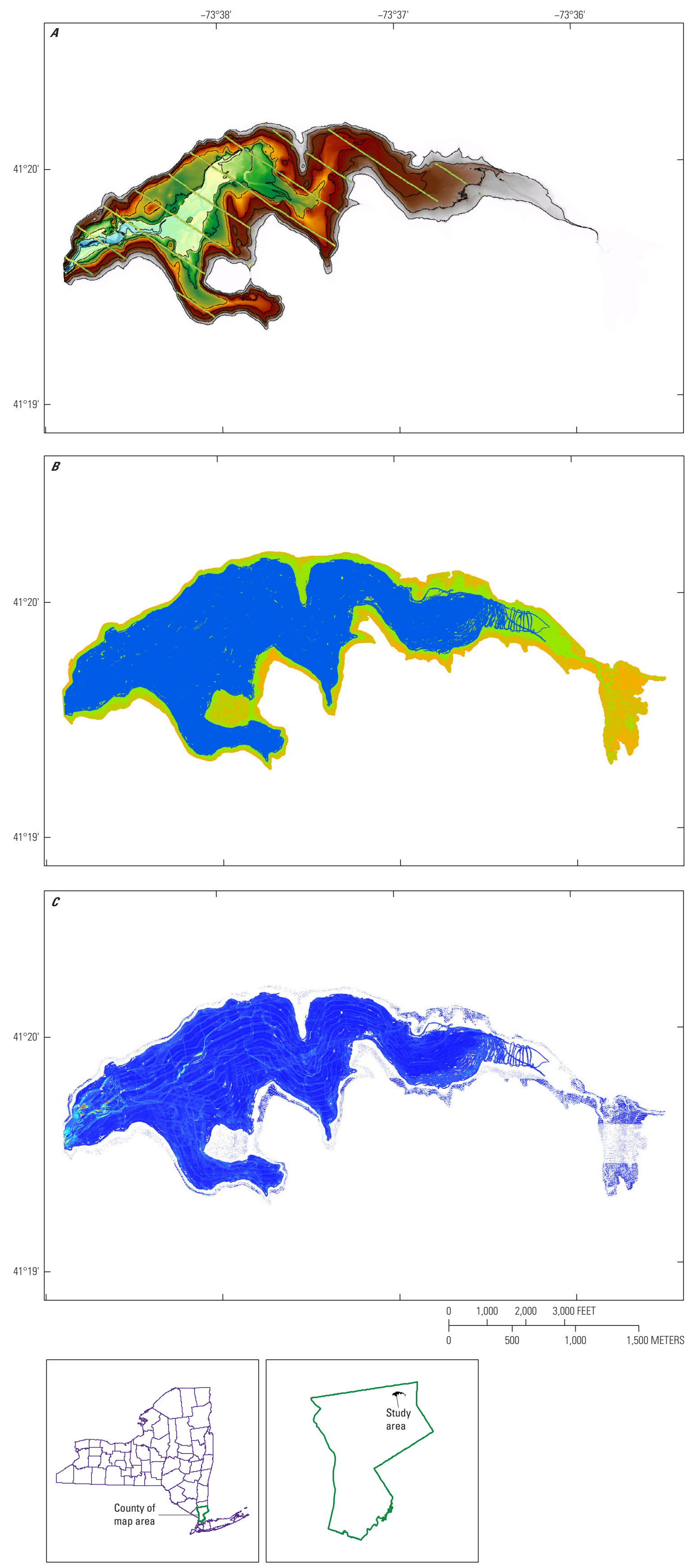

\section{EXPLANATION}

\begin{tabular}{|c|c|}
\hline $\begin{array}{l}\text { Elevation, in feet above } \\
\text { NAVD } 88 \\
\text { - High : } 323.23 \\
\end{array}$ & $\begin{array}{l}\text {-10-foot contour interval } \\
\text { Quality assurance poin } \\
\text { elevation minus grid } \\
\text { elevation, in feet }\end{array}$ \\
\hline Low : 237.27 & -2.17 to -2.00 \\
\hline $\begin{array}{l}\text { Standard deviation of } \\
\text { elevation values } \\
\text { within grid cell, } \\
\text { in feet }\end{array}$ & $\begin{array}{l}-1.99 \text { to }-1.00 \\
-0.99 \text { to }-0.50 \\
-0.499 \text { to } 0.00 \\
0.01 \text { to } 0.50\end{array}$ \\
\hline High: 3 & $\begin{array}{l}0.51 \text { to } 1.00 \\
1.01 \text { to } 2.00\end{array}$ \\
\hline $\begin{array}{l}\text { Low: } 0 \\
\text { Source of elevation data }\end{array}$ & 2.01 to 4.00 \\
\hline $\begin{array}{l}\text { Source of elevation data } \\
\text { in grid cell }\end{array}$ & $\begin{array}{l}4.01 \text { to } 6.00 \\
6.01 \text { to } 8.00\end{array}$ \\
\hline $\begin{array}{l}\text { Multibeam echosounder } \\
\text { Lidar } \\
\text { Estimated } \\
\text { Interpolated }\end{array}$ & 8.01 to 13.40 \\
\hline
\end{tabular}

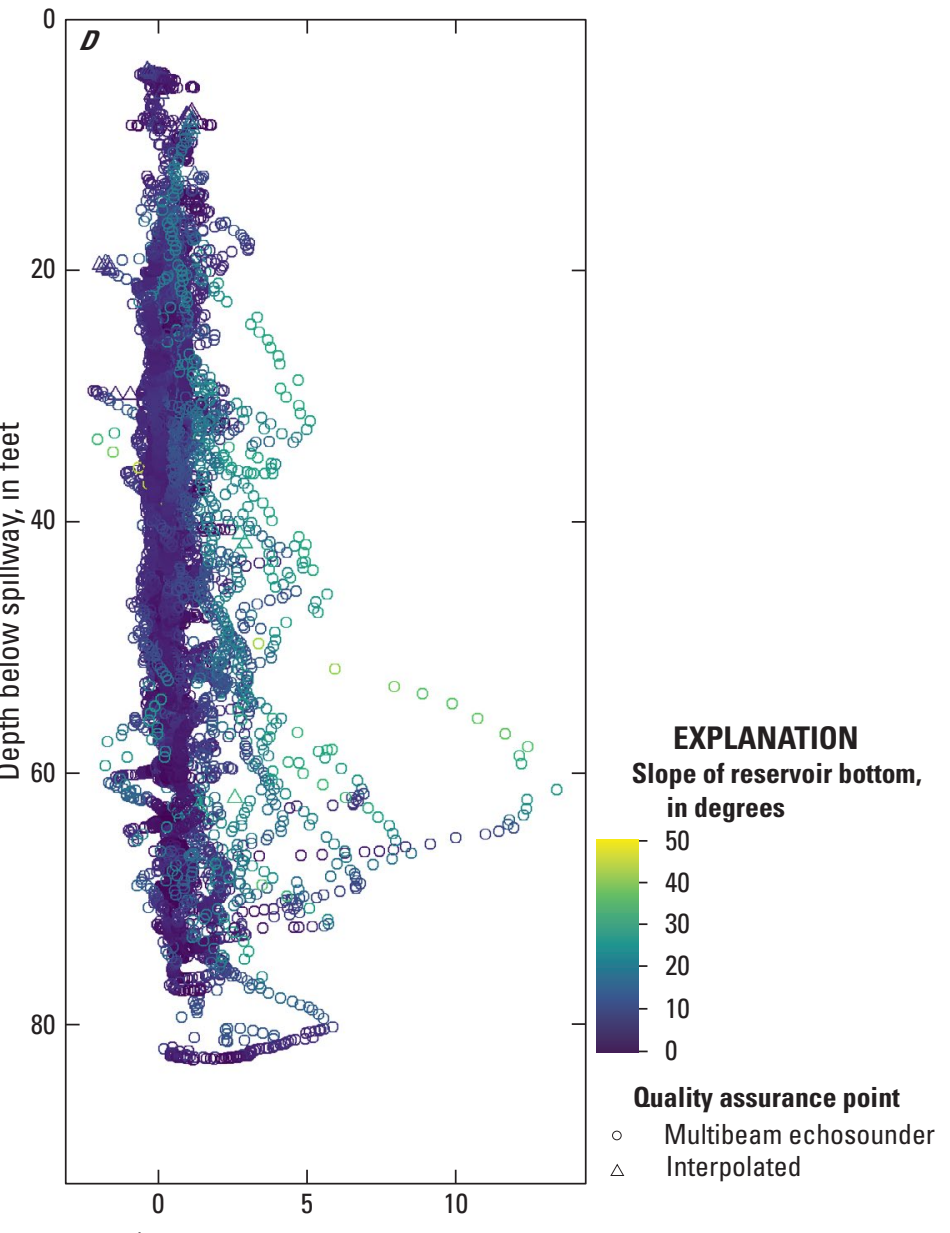

Error (elevation of quality assurance point minus mapped elevation), in feet

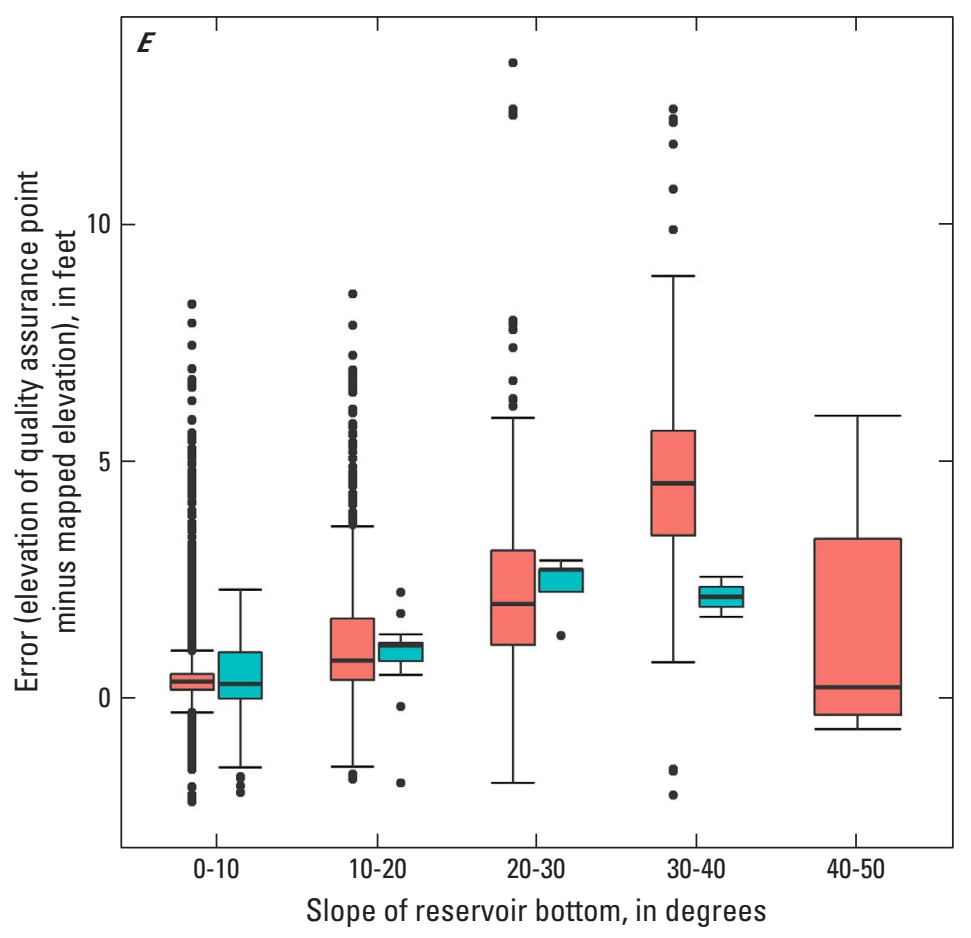

EXPLANATION

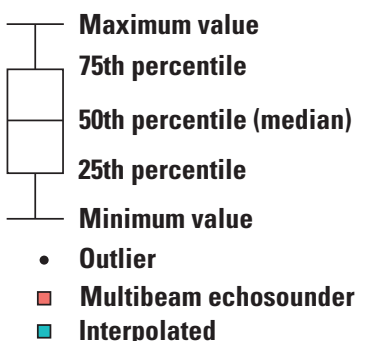

Figure 24. Results of bathymetric mapping of Titicus Reservoir in Westchester County, New York, including maps of $A$, bathymetric elevations, contours, and quality assurance points, $B$, source data type, and $C$, cell standard deviation; and plots showing comparison of quality assurance points and mapped elevation $D$, by depth and slope and $E$, by grid cell data source. Mapped data are from Nystrom and others (2021). Lidar, light detection and ranging; NAVD 88; North American Vertical Datum of 1988. A large version of this figure is available for download at https://doi.org/10.3133/sir20215057. 

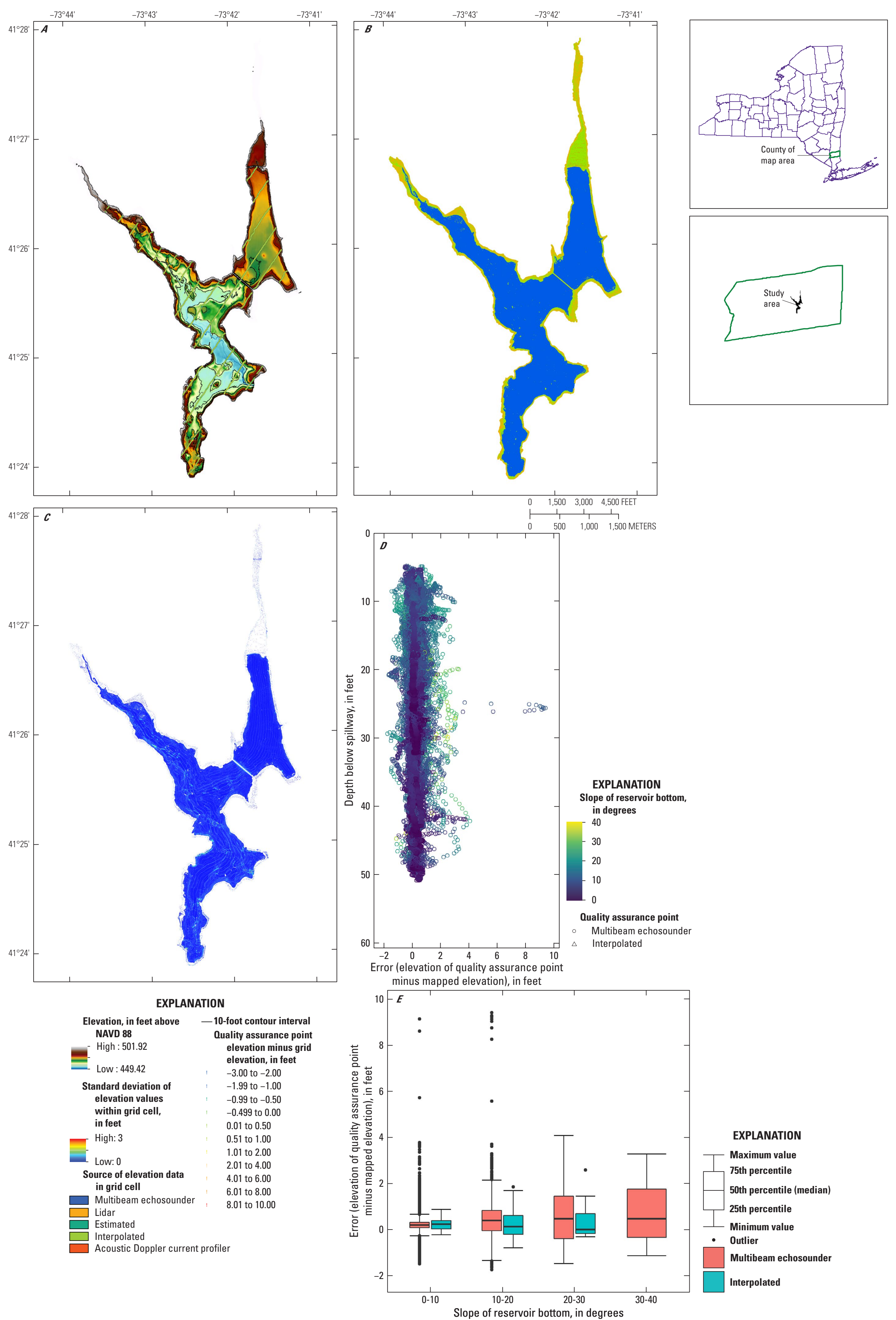

Figure 25. Results of bathymetric mapping of West Branch Reservoir in Putnam County, New York, including maps of $A$, bathymetric elevations, contours, and quality assurance points, $B$, source data type, and $C$, cell standard deviation; and plots showing comparison of quality assurance points and mapped elevation $D$, by depth and slope and $E$, by grid cell data source. Mapped data are from Nystrom and others (2021). Lidar, light detection and ranging; NAVD 88; North American Vertical Datum of 1988. A large version of this figure is available for download at https://doi.org/10.3133/sir20215057. 
For more information, contact

Director, New York Water Science Center

U.S. Geological Survey

425 Jordan Road

Troy, NY 12180-8349

dc_ny@usgs.gov

or visit our website at

https://www.usgs.gov/centers/ny-water

Publishing support provided by the

Pembroke Publishing Service Center 

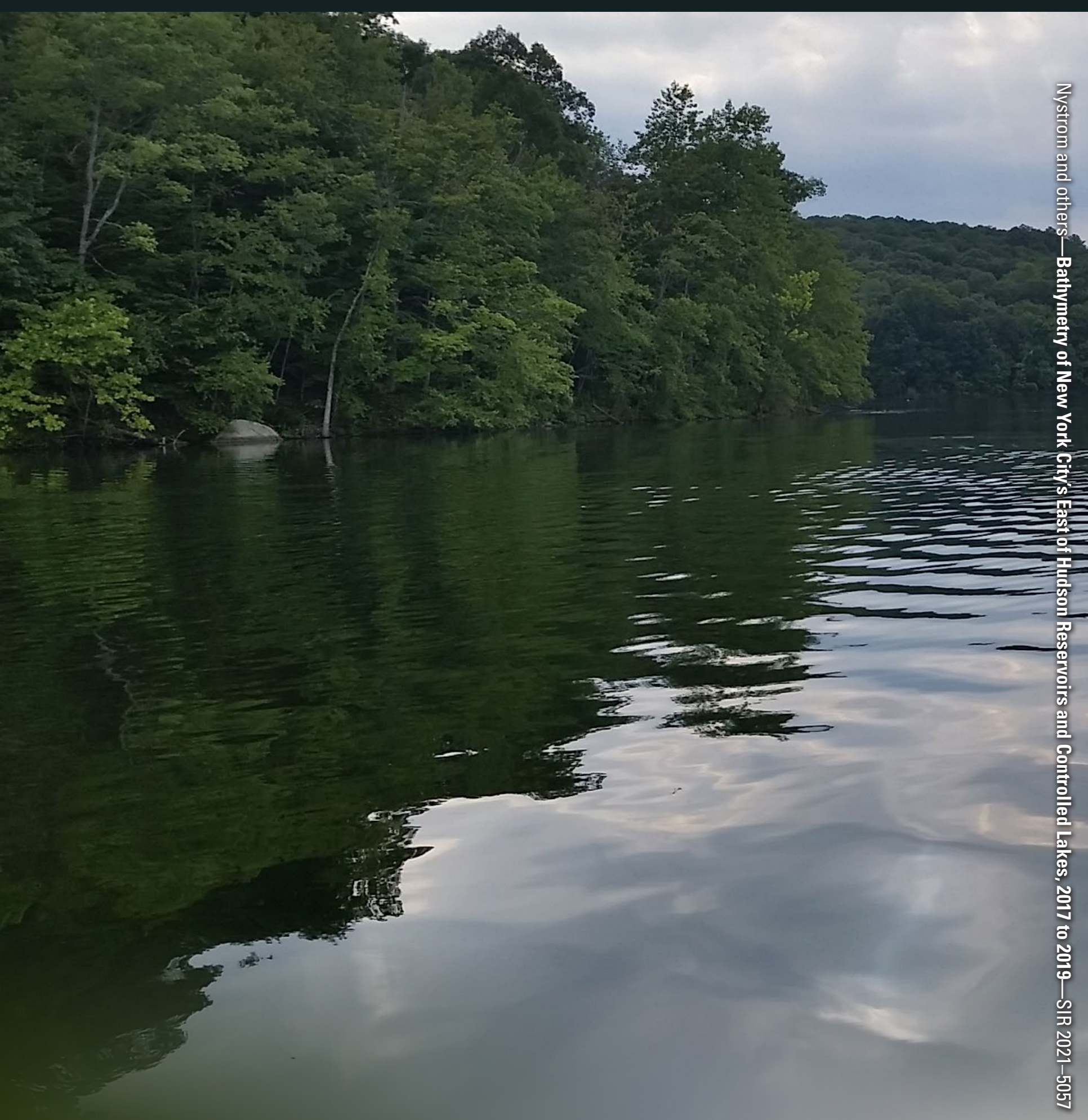